\title{
THE SUSTAINABILITY OF BIOFUELS: A PRINCIPLED LIFECYCLE ASSESSMENT OF THE 2009 EUROPEAN UNION RENEWABLE ENERGY DIRECTIVE AND ITS FRAMEWORK
}

\author{
by \\ Pierre Cloutier de Repentigny \\ LL.L., University of Ottawa, 2009 \\ LL.B., University of Ottawa, 2010
}

\begin{abstract}
A THESIS SUBMITTED IN PARTIAL FULFILLMENT OF THE REQUIREMENTS FOR THE DEGREE OF
\end{abstract}

\author{
MASTER OF LAWS
}

in

The Faculty of Graduate and Postdoctoral Studies

(Law)
THE UNIVERSITY OF BRITISH COLUMBIA
(Vancouver)

April 2016

(C) Pierre Cloutier de Repentigny, 2016 


\section{Abstract}

Drastic reductions in greenhouse gas $(\mathrm{GHG})$ emissions are needed in order to mitigate the effects of climate change. The European Union (EU), a leader in climate change mitigation, has adopted an ambitious strategy to achieve its mitigation goal. A piece of this strategy is the Renewable Energy Directive. The Directive establishes mandatory renewable energy targets for member states. Cognizant that in order to achieve the target of $10 \%$ of final energy consumption in the transport sector member states would have to rely heavily on biofuels, the EU, in the spirit of sustainable development, included in the Directive sustainability criteria for biofuels. The criteria were needed because, although biofuels can be carbon neutral and an effective replacement for fossil fuels, the production of biofuels can have serious environmental and socio-economic consequences.

This thesis concludes that the Directive will not result in the sustainable production of biofuels. This conclusion is based on the principled lifecycle assessment of the Directive and its framework. This approach is a combination of core principles of sustainable development - integration, equity, precaution and polluter pays - and of the basic tenets of lifecycle assessment, a methodology designed to measure the lifecycle impacts of a product.

Due to the reliance by member states on first generation biofuels, biofuels produced under the Directive's regime are not likely to reduce GHG emissions compared to fossil fuels, and are likely to increase water pollution, the loss of biodiversity and food 
insecurity. The negative impacts of biofuels production are caused mainly by the agricultural production of feedstocks, especially through indirect land-use change. Furthermore, the cost of pollution is not internalized by the regime and biofuels subsidies are not linked to environmental concerns. Therefore, the lifecycle impacts of EU biofuels production do not accord with core principles of sustainable development. Only second and third generation biofuels, which are not yet available on a large-scale, seem to have the potential to be sustainable. 


\section{Preface}

This thesis is the original, unpublished, independent work of the author. 


\section{Table of Contents}

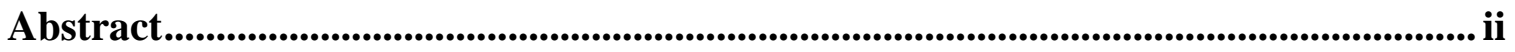

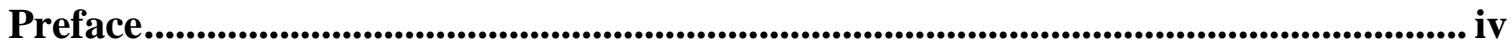

Table of Contents ....................................................................................................... v

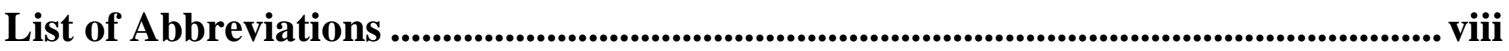

Acknowledgements ................................................................................................................... ix

Chapter 1 - Biofuels, a Double Edged Sword: An Introduction ...................................... 1

1. Replacing Fossil Fuels: Biofuels in Context........................................................... 1

2. The Biofuels Dilemma: Solution or Problem?......................................................... 3

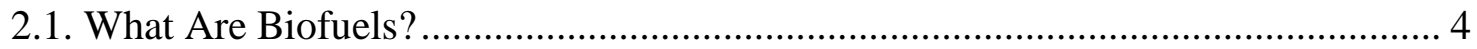

2.2. The Energy Source of Tomorrow: Positive Aspects of Biofuels .......................... 6

2.3. Fossil fuels of Tomorrow: Negative Aspects of Biofuels ................................... 9

3. Regulating Biofuels and Sustainability: Research Framework ................................. 13

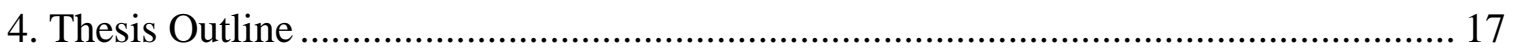

Chapter 2 - Sustainable from Birth to Death: Lifecycle Assessment and Sustainable Development Principles .................................................................................................... 18

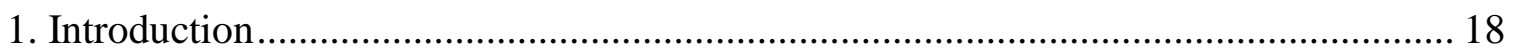

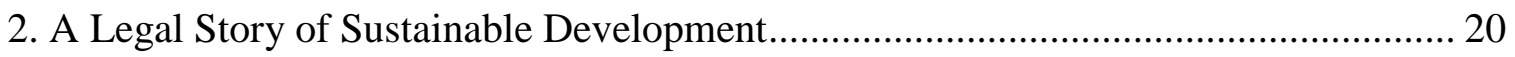

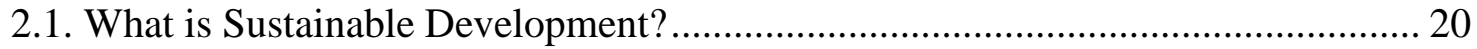

2.2. The Relevance of Sustainable Development.................................................. 23

3. A Guide for Sustainability: The Principles of Sustainable Development.................... 25

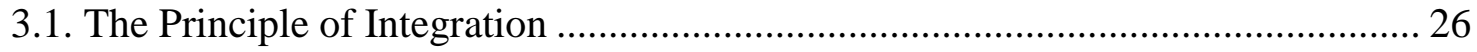

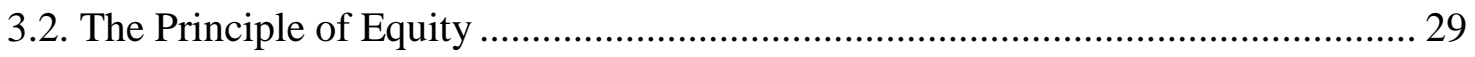

3.3. The Polluter Pays Principle and the Precautionary Principle .............................. 34

4. Lifecycle Assessment and Law: Adapting the Methodology for Legislative Schemes 38

4.1. From Cradle to Grave: Lifecycle Assessment.................................................... 39

4.2. A Principled Approach: Lifecycle Assessment and Legislation ......................... 42

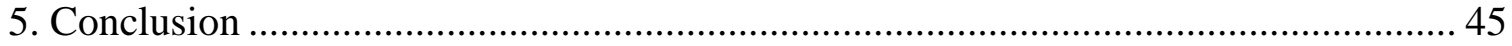


Chapter 3 - The EU's Direction: The Renewable Energy Directive and Its Setting 47

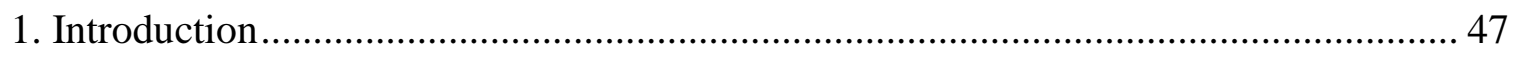

2. A Peculiar Type of Law: Background on the EU Legal Framework .......................... 49

2.1. Supra-national Complexity: The Law Making Power of the EU .......................... 49

2.2. A Question of Competence: The EU Environmental and Energy Jurisdiction ...... 52

2.2.1. Established Competences: Protecting and Improving the Environment ......... 53

2.2.2. Contested Territory: Jurisdiction over Energy …........................................ 56

3. A Second Chance for Biofuels: The 2009 Renewable Energy Directive .................... 57

3.1. A Tortuous Road: Legislative Development Leading to the Directive ...................58

3.2. Renewable Energy and Biofuels: The Purpose and Provisions of the Directive ... 60

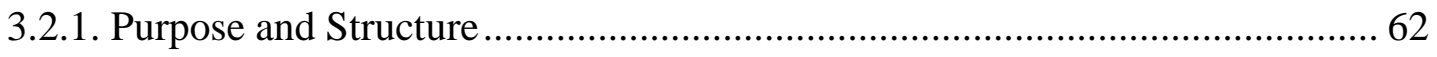

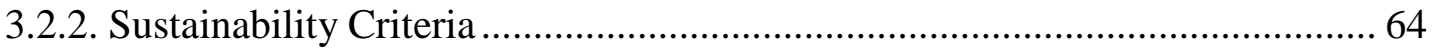

4. The Bigger Picture: Other EU Norms Affecting Biofuels ....................................... 71

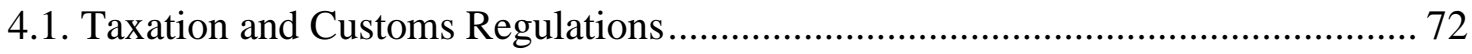

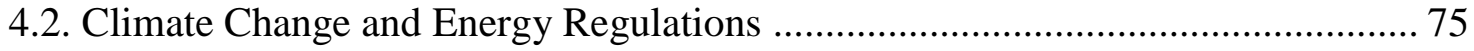

4.2.1. Climate Change Mitigation .................................................................. 76

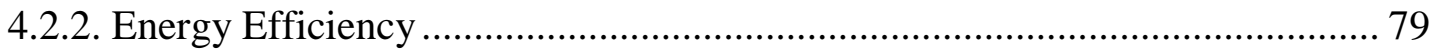

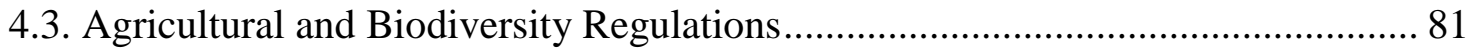

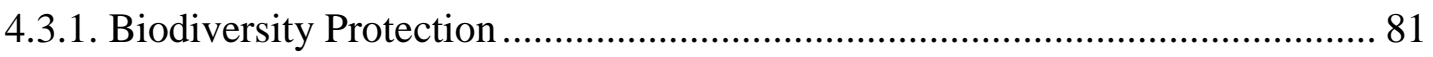

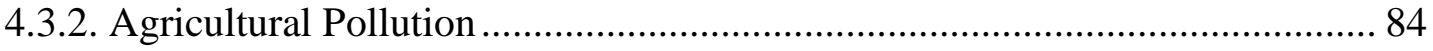

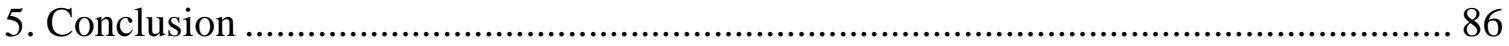

Chapter 4 - Shades of Green: Assessing the Sustainability of the EU Biofuels

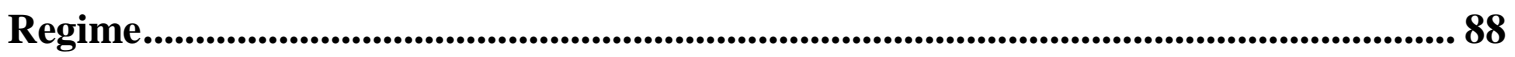

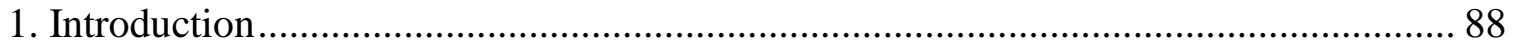

2. The Underlying Sustainability: Assessing the Impacts of Biofuels ........................... 89

2.1. The Green Haemorrhage: Environmental Impacts......................................... 90

2.1.1. The Main Issue: GHG Emissions and Energy Concerns ............................... 90

2.1.2. Other Environmental Aspects: Biodiversity and Water Quality .................... 93

2.2. Beyond Environmental Concerns: Social Impacts ........................................ 98

2.2.1. Human Considerations: Labour and Food Security ...................................... 99 
2.2.2. It's the Economy Stupid: Taxes, Subsidies and Funding 103

3. Sustainable in Practice? Assessing a Sample of EU Biofuels ..................................... 106

3.1. The Agro-Energy Industry: First Generation Biofuels ........................................ 106

3.2. A House of Straw: Second Generation Biofuels .................................................. 110

3.3. A little Help from Sun and Water: Third Generation Biofuels ........................... 112

4. Sustainable in Theory: Assessing the Essence of the Directive ................................ 115

4.1. An Integrated Directive? Lifecycle and the Integration Principle ........................ 115

4.1.1. Core Provisions: Integration in the Directive .............................................. 116

4.1.2. Supplemental Provisions: Integration through the Framework ...................... 120

4.2. Analysing Equity: The Mitigation of Biofuels Impacts by the Directive ............ 124

4.2.1. Inter-generational Equity and the EU Biofuels Industry ............................... 125

4.2.2. Intra-generational Equity, Polluter Pays, and Biofuels' Socio-economic Impacts.

4.3. Interpreting the Results: Synthesizing the Principled Lifecycle Assessment ...... 132

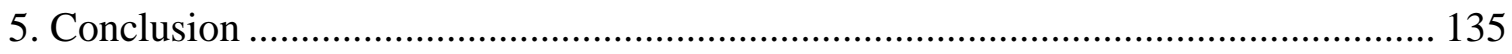

Chapter 5 - When Good Intentions Are Not Enough: Recommendations and

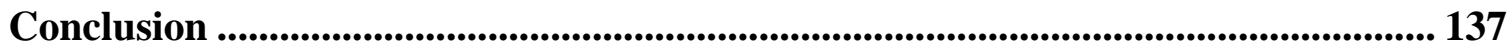

1. Reflections on the Sustainability of Biofuels Production: Some Recommendations. 137

1.1. Climate Change Mitigation: Are Biofuels a Realistic Option? ............................ 138

1.2. A Sustainable Renewable Energy Directive: Recommendations ....................... 139

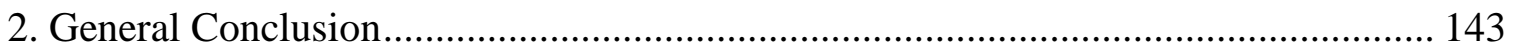

2.1. Dreaming of Sustainability: The Renewable Energy Directive ............................ 143

2.2. Achieving Sustainability? A Principled Lifecycle Assessment ............................ 144

2.3. The Road Ahead: Next Research Steps............................................................. 147

Bibliography .................................................................................................................................. 150 


\section{List of Abbreviations}

CAP - Common Agricultural Policy

ECJ - European Court of Justice

ETS - European Union Emissions Trading System

EU - European Union

GHG - greenhouse gas

GSP - Generalised Scheme of Preferences

ILO - International Labour Organisation

ILUC - indirect land-use change

JPI - Johannesburg Plan of Implementation

$\mathrm{NGO}$ - non-governmental organisation

TEU - Treaty on European Union

TFEU - Treaty on the Functioning of the European Union

US - United States of America

WSSD - World Summit on Sustainable Development 


\section{Acknowledgements}

I would like to thank my supervisor, Karin Mickelson, for her insight, engagement and comments. When she agreed to take me on as a student after I went through very difficult times, she told me that she wanted to make what was left of my time at UBC a positive experience. She succeeded. I could have not asked for a better supervisor. Additionally, I would like to thank Ljiljana Biuković, my second reader, for her helpful comments. Thank you also to Douglas Harris, my interim supervisor, Benjamin Richardson, my former supervisor, Natasha Affolder, Mary Liston, and Yves Le Bouthillier for their advice and comments.

My thanks also go to Joanne Chung, Graduate Student Coordinator, and my parents, Marie Cloutier and Yves de Repentigny, for their constant support and encouragement.

Finally, I offer my deepest gratitude to Nina M. Pinakamaganda for their never ending and unconditional support. Without them, this project would have never seen the light of day. 


\section{Chapter 1 - Biofuels, a Double Edged Sword: An Introduction}

\section{Replacing Fossil Fuels: Biofuels in Context}

Our dependence on fossil fuels is undeniable. The use of such fuels has caused a plethora of problems, including contributing to climate change. This global problem represents one of the biggest challenges for the international community. Mitigating this problem will require considerable efforts and innovations, both technical and intellectual. Specifically, we will have to think about energy differently. Reducing energy consumption through conservation and improved technology will surely play a part. However, since it is difficult to think of a world where humanity consumes no energy, we also have to find replacements for fossil fuels. While progress has been made in recent years to improve our use of renewable energy, road transportation still functions mainly with fossil fuels. Transport represents $14 \%$ of global greenhouse gas (hereafter GHG) emissions. ${ }^{1}$ This sector accounts for $24.3 \%$ of the European Union's (hereafter the EU) GHG emissions and $71.9 \%$ of these emissions come from road transportation. ${ }^{2}$ It is thus reasonable that many, including EU institutions, would view biofuels, a renewable source of energy that can replace fossil fuels for motor vehicles and other forms of transportation, as the most promising solution to reduce GHG emissions in transportation. After all, as long as we can grow crops or cultivate biomass, we have an endless source of theoretically carbon neutral fuel. At least that was the idea. Reality quickly caught up

\footnotetext{
${ }^{1}$ Rajendra K Pachauri et al, Climate Change 2014 - Synthesis Report (Geneva: Intergovernmental Panel on Climate Change, 2014) at 46.

${ }^{2}$ EU, Commission, Directorate-general for Climate Action, Reducing emissions from transport, online: www.ec.europa.eu < http://ec.europa.eu/clima/policies/transport/index_en.htm $>$.
} 
with us. As Mats Karlsson, former Chair of UN-Energy, stated, "nothing human or ecological is straightforward. And so it is with biofuels, perhaps particularly liquid biofuels." ${ }^{3}$ The complexity of biofuels alluded to by Mr. Karlsson manifests itself through their numerous lifecycle social and environmental impacts. Unless such impacts can be mitigated, biofuels may end up as damaging as the fossil fuels they seek to replace. The EU thus needed a framework or concept capable of dealing with the impacts of biofuels.

A concept that is designed to deal with complex socio-economic and environmental issues is sustainable development. Sustainable development is found in an impressive number of treaties and other international law documents. ${ }^{4}$ In fact sustainable development is one of the principles of the United Nations Framework Convention on

\section{Climate Change:}

The Parties have a right to, and should, promote sustainable development. Policies and measures to protect the climate system against humaninduced change should be appropriate for the specific conditions of each Party and should be integrated with national development programmes, taking into account that economic development is essential for adopting measures to address climate change. ${ }^{5}$ [emphasis added]

It is in the spirit of sustainable development that the EU adopted in 2009 the Renewable Energy Directive which creates a framework for the EU to reduce GHG emitting forms of energy such as oil, coal and natural gas. ${ }^{6}$ Biofuels are at the center of the Directive. As

\footnotetext{
${ }^{3}$ UN-Energy, Sustainable Bioenergy: A Framework for Decision Makers (United Nations, 2007) at 1.

${ }^{4}$ Duncan French, "Sustainable Development" in Malgosia Fitzmaurice, David M Ong \& Panos Merkouris, eds, Research Handbook on International Environmental Law (Cheltenham, UK: Edward Elgar Publishing, 2010) at 57-58.

${ }^{5}$ Article 3(4) of the United Nations Framework Convention on Climate Change, 9 May 1992, 1771 UNTS 107.

${ }^{6}$ EC, Directive 2009/28 of the European Parliament and of the Council of 23 April 2009 on the promotion of the use of energy from renewable sources and amending and subsequently repealing Directives 2001/77/EC and 2003/30/EC, [2009] OJ, L 140/16 [Renewable Energy Directive].
} 
the EU was aware that the use of biofuels was not free of consequences, the Directive creates a set of sustainability criteria to ensure the ecological and social viability of biofuels. This thesis attempts to determine if the EU legal mechanism to foster sustainable biofuels is adequate in light of sustainable development as defined by international law and of the lifecycle impacts of biofuels. This chapter introduces issues related to biofuels, and the goals and structure of this thesis.

\section{The Biofuels Dilemma: Solution or Problem?}

At first biofuels production may not necessarily seem problematic as it is often viewed as a renewable source of energy most commonly known for its use in the transportation sector. However, with biofuels come a plethora of issues and implications, some bad and some good. One of the main benefits of biofuels is their potential to be carbon neutral, ${ }^{7}$ meaning emitting no GHGs. The use of biofuels is thus an attractive mitigation measure for the ecological disaster that is climate change. Unsurprisingly, the development of these products grew very rapidly in the last few years. ${ }^{8}$ However, in a sad twist of fate, the solution caused more problems than it fixed. These issues are aptly summarised by an article in The Guardian entitled Biofuels are not a green alternative to fossil fuels: "[bioenergy] uses land needed for food production and carbon storage, it requires large areas to generate just a small amount of fuel, and it won't typically cut

\footnotetext{
${ }^{7}$ Biofuels are made from biomass that gets its needed carbon from the atmosphere. When the fuel is burned, the same amount of carbon originally absorbed returns to the atmosphere, making biofuels carbon neutral. In some circumstances, biofuels could be more polluting GHGs wise than fossil fuels. See Rudolf M Smaling, "Environmental Barriers to Widespread Implementation of Biofuels" (2007-2008) 2 Envtl \& Energy L \& Pol'y J 287.

${ }^{8}$ The two main biofuels are bioethanol and biodiesel. From 2000 to 2007 the production of bioethanol has tripled and the production of biodiesel went up eleven-fold: UNEP, Toward Sustainable Production and Use of Resources: Assessing Biofuels (Nairobi: United Nations Environmental Program, 2009) at 15.
} 
greenhouse gas emissions." ${ }^{9}$ Additionally, biofuels production can create significant agricultural pollution. A BBC News correspondent even went as far as stating that EU and United Kingdom's biofuels use is "irrational" and that biofuels are "worse than fossil fuels". 10

Does this means that biofuels are to be discarded? Not necessarily. It is not a perfect solution, but biofuels still have some merits and there might be a way to mitigate their negative impacts. At the very least, they can play their part as a transitional form of energy as we research greener alternatives. The impacts caused by biofuels and thus their viability as a source of energy will depend on how they are regulated. Only a wellregulated biofuel industry can play a positive role in climate mitigation. Before looking in detail at how this thesis approaches the subject of EU biofuels regulation, this section of the introduction contextualises the topic by defining the term biofuel and by summarizing the impacts of biofuels production.

\subsection{What Are Biofuels?}

Bioenergy has great potential as all you need to create it is some biomass. Simply defined, bioenergy is "energy produced from organic matter or biomass". ${ }^{11}$ It offers the possibility of using things such as household organic waste (like bones, egg shells, and vegetable cutoffs) to create fuel for cars and trucks. This possibility is not just hypothetical, as waste biofuels plants in the United States have begun commercial

\footnotetext{
${ }^{9}$ Andrew Steer \& Craig Hanson, Biofuels are not a green alternative to fossil fuels, 29 January 2015, The Guardian, online: www.theguardian.com < http://www.theguardian.com/environment/2015/jan/29/biofuelsare-not-the-green-alternative-to-fossil-fuels-they-are-sold-as $>$.

${ }^{10}$ Matt McGrath, Biofuels: 'Irrational' and 'worse than fossil fuels', BBC News, 15 April 2013, online: www.bbc.com < http://www.bbc.com/news/science-environment-22127123 $>$.

${ }^{11} \mathrm{UN}-$ Energy, supra note 3 at 3.
} 
production. ${ }^{12}$ A biofuel is, according to the United Nations Food and Agriculture Organisation, a "fuel of renewable and biological origin, including woodfuel, charcoal, livestock manure, biogas, agricultural wastes and by-products, and energy crops." ${ }^{13}$ The Renewable Energy Directive defines biofuels as "liquid or gaseous fuel for transport produced from biomass"14 and defines biomass as "the biodegradable fraction of products, waste and residues from biological origin from agriculture (including vegetable and animal substances), forestry and related industries including fisheries and aquaculture, as well as the biodegradable fraction of industrial and municipal waste." 15 Biofuels are typically divided into first and second generation. First generation biofuels are "made from sugar, starch, vegetable oil, or animal fats using conventional technology." 16 They are currently the most common type of biofuels. Second generation biofuels (also called advanced biofuels) are made with lignocellulosic biomass feedstocks (inedible plant material such as wood particles or harvest residues) using advanced technical processes to transform the biomass into sugar or fat that is then used to make biofuels. ${ }^{17}$ There is also an emerging third generation of biofuels made from algae. ${ }^{18}$ The most common biofuels are biodiesel, ${ }^{19}$ bioethanol ${ }^{20}$ and vegetable oils. ${ }^{21}$ Bioethanol can

\footnotetext{
${ }^{12}$ Matthew L Wald, Fuel From Waste, Poised at a Milestone, New York Times, 13 November 2012, online: $\quad$ www.nytimes.com $\quad<\quad$ http://www.nytimes.com/2012/11/14/business/energyenvironment/alternative-fuels-long-delayed-promise-might-be-near-fruition.html >.

${ }^{13}$ Charlotta Jull et al, Recent Trends in the Law and Policy of Bioenergy Production, Promotion and Use, FAO Legal Paper \#68 (Rome: Food and Agriculture Organization, 2007) at 3.

${ }^{14}$ Article 2(i) of the Renewable Energy Directive, supra note 6.

${ }^{15}$ Article 2(e), ibid.

${ }^{16} \mathrm{UN}$-Energy, supra note 3 at 4.

${ }^{17}$ Ibid at 4 \& 12.

${ }^{18}$ UNEP, supra note 8 at 25 . "Algae are feedstocks from aquatic cultivation for production of triglycerides (form algal oil) to produce biodiesel. The processing technology is basically the same as for biodiesel from second-generation feedstocks."

${ }^{19}$ Biodiesel is a fuel for diesel engines derived from natural oils. "Biodiesel is defined as the mono alkyl esters of long-carbon-chain fatty acids derived from renewable lipid feedstocks": NREL, Biodiesel and Other Renewable Diesel Fuels, Pub \# NREL/FS-510-40419 (Golden, CO: National Renewable Energy Laboratory, 2006).
} 
provide a substitute for gasoline, while biodiesel and vegetable oils can provide a substitute for diesel.

\subsection{The Energy Source of Tomorrow: Positive Aspects of Biofuels}

Paul Wolfowitz, former President of the World Bank, effectively summarized the positive side of biofuels:

[Bioenergy] is an opportunity to add to the world supply of energy to meet the enormous growing demand and hopefully to mitigate some of the price effects. It's an opportunity to do so in an environmentally friendly way and in a way that is carbon neutral. It's an opportunity to do so in a way that developing countries like Brazil can provide income and employment for their people. ${ }^{22}$

The words of Mr. Wolfowitz identify clearly the three areas in which biofuels can play an important role: climate change mitigation, energy security and economic development.

On the climate change front, different types of bioenergy have different GHG emissions savings potential compared to fossil fuels. The use of non-mixed biofuels does not produce GHG emissions upon combustion (except the carbon absorbed by the biomass during its life), and is therefore known as "carbon neutral". Its transportation, if done by pipelines and by vehicles and ships fueled with biofuels, can also be carbon neutral. $^{23}$ The same goes for the agricultural equipment, refineries, power plants, etc., needed to create biofuels. Since bioethanol and biodiesel can easily replace gasoline and

\footnotetext{
${ }^{20}$ The US Department of Energy defines ethanol as "a renewable fuel made from various plant materials, which collectively are called 'biomass.' Ethanol contains the same chemical compound $(\mathrm{C} 2 \mathrm{H} 5 \mathrm{OH})$ found in alcoholic beverages": United States Department of Energy, Alternative Fuels Data Center, Ethanol Fuels Basics, online: www.afdc.energy.gov < http://www.afdc.energy.gov/afdc/ethanol/basics.html >.

${ }^{21}$ Roland M Stein, "Import of Biofuels and the Marketing of Biofuels in the European Union: an Analysis of the Current Law on Customs, Energy Taxes and Biofuel Quotas" (2008) 26 J Energy \& Nat'l Res L 600 at 601 .

${ }^{22}$ UN-Energy, supra note 3 at 3 .

${ }^{23}$ UNEP, supra note 8 at 52; and Joyce Tait et al, Biofuels: ethical issues (London: Nuffield Council on Bioethics, 2011) at 19.
} 
diesel for transportation, biofuels could hypothetically and with relative ease nullify the GHG emissions of cars, trucks, planes, etc. Fossil fuels would be a thing of the past. In reality, however, the GHG emissions savings potential of biofuels varies greatly between feedstocks and within a feedstock depending on the land use (e.g. using land already used for agricultural purposes instead of converting forest land into a feedstock plantation) and the production process. In other words GHG emissions savings depend on the lifecycle of the biofuel. GHG emissions savings is the amount of GHGs that is reduced by using a particular biofuel instead of a fossil fuel. For example, a saving of $25 \%$ means that bioethanol $\mathrm{X}$ produces $25 \%$ less $\mathrm{GHG}$ emissions than gasoline. A negative numbers in savings means that a particular biofuel produces more GHG emissions than its fossil fuel counterpart. The savings vary from a range of $70 \%$ to $143 \%$ for bioethanol made from sugar cane, to a range of $-2070 \%$ to $80 \%$ for biodiesel made from palm oil. Some of the more stable biofuels in term of savings range are bioethanol made from agricultural and forestry residues (around $80 \%$ to $90 \%$ ) and biodiesel made from sunflower oil (around $35 \%$ to $110 \%) .{ }^{24}$ One study done in the EU, using biodiesel and bioethanol available in the EU, indicates the percentage of GHG emissions savings using a petroleum diesel and gasoline baseline. The savings for ethanol made from sugar beets range from $50 \%$ to $65 \%$ and the ones for ethanol made from grains vary from $8.5 \%$ to $18 \% .{ }^{25}$ For biodiesel made from used cooking oil, the savings vary from $85 \%$ to $89 \%$, and the ones for biodiesel made from canola oil range from $23 \%$ to $30 \% .{ }^{26}$ Therefore, with a good policy in place, it

\footnotetext{
${ }^{24}$ UNEP, ibid at 54.

25 Anna Jung et al, Biofuels - At What Cost? Government Support for Ethanol and Biodiesel in the European Union - 2010 Update (Geneva: International Institute for Sustainable Development, 2010 ) at 68.

${ }^{26}$ Ibid at 69.
} 
is possible to ensure the use of biofuels with good GHG emissions savings and consequently significantly reduce GHG emissions in the transport sector.

Biofuels can also contribute to the energy security of the world's poor, ${ }^{27}$ by providing an energy source made from readily available biomass to the poorest who may not have the means to buy the fuel they need or have access to a modern source of energy. ${ }^{28}$ Bioenergy is viewed as a key source for the diversification and accessibility of energy supply. ${ }^{29}$ Biofuels can reduce a state's dependence on fossil fuels importation. Since any nation can in theory grow the feedstocks necessary to produce biofuels, bioenergy offers the possibility of complete energy independence to nearly all nations. Biofuels can also be a powerful tool of economic development. Its production can be quite labour intensive compared to fossil fuels production. A successful bioenergy industry creates high, medium and low skilled jobs, including engineers, economists, bioenergy plants' technical staff, low skilled industrial plant workers and farmers. ${ }^{30}$ The energy created with biofuels can also power other industries, especially in the agroindustrial field and in developing countries. ${ }^{31}$ This is particularly true when we consider the flexibility of bioenergy: electricity, process heat, steam production, mechanical

\footnotetext{
${ }^{27}$ The European Commission defines energy security as "the uninterrupted physical availability of energy products on the market, at a price which is affordable for all consumers (private and industrial)": European Commission, Directorate-General for Energy and Transport, Green Paper: Towards a European strategy for the security of energy supply (Luxemburg: Office for Official Publications of the European Communities, 2001) at 3.

${ }^{28}$ Tait et al, supra note 23 at 15-16. I exclude from modern sources of energy traditional energy sources such as wood burning and feces burning: UN-Energy, supra note 3 at 7-9. See $\mathrm{p} 8$ for an example on the usefulness of bioenergy in developing countries' communities. With some technical and financial assistance, local communities can produce their own bioenergy. Agricultural residues can be used to produce bioenergy like biogas and liquid biofuels. Small bioenergy plants using vegetable oil or biodiesel can even power small villages who did not have access to electricity before. Moreover, using agricultural residues also limits the impact of biofuels on agricultural products and limits the dilemma of "fuel or feed".

${ }^{29}$ Tait et al, ibid at 13.

${ }^{30}$ UN-Energy, supra note 3 at 15 ; and Tait et al, ibid at 15-16.

${ }^{31}$ UN-Energy, ibid at 12-13; and Tait et al, ibid at 15.
} 
power, etc. For example, the pulp mills industry in Finland and Sweden satisfies its own energy needs by using wood residue to produce bioethanol. The sugar cane industry was able to achieve self-sufficiency and even sell power to surrounding energy grids in Australia, Brazil, Cuba, Guatemala, India, Mauritius and other states. ${ }^{32}$

\subsection{Fossil fuels of Tomorrow: Negative Aspects of Biofuels}

While biofuels offer many benefits, they come at a price. Biofuels, as products, have very few impacts when combusted. It is rather the production, or the lifecycle, of biofuels that creates numerous socio-economic and environmental impacts. ${ }^{33}$ One of the impacts of biofuels production is food insecurity. A New York Times headline puts the issue quite poignantly: As biofuel demand grows, so do Guatemala's hunger pangs. ${ }^{34}$ Food insecurity or undernourishment is a calamity that still afflicts $16 \%$ of the global population. Although the number of undernourished people is decreasing, after an increase from 2006 to 2009 due to high world food prices, many still do not have sufficient access to food. ${ }^{35}$ Bioenergy partly contributes to this problem by creating a higher demand for food crops, such as corn and soy, used for creating biofuels. This is due to the fact that first generation liquid biofuels are made of agricultural feedstocks rich in fat or sugar. ${ }^{36}$ This demand diminishes the availability of agricultural products for food

\footnotetext{
${ }^{32} \mathrm{UN}-$ Energy, ibid at 16.

${ }^{33}$ UNEP, supra note 8 at 65.

${ }^{34}$ Elisabeth Rosenthal, As Biofuel Demand Grows, So Do Guatemala's Hunger Pangs, New York Times, 5 January 2013, online: www.nytimes.com < http://www.nytimes.com/2013/01/06/science/earth/in-fieldsand-markets-guatemalans-feel-squeeze-of-biofuel-demand.html?ref=topics $>$.

${ }^{35}$ FAO, The State of Food Insecurity in the World (Rome: Food and Agriculture Organization, 2010 ) at 8. 925 million people were undernourished in 2010. They were just above a billion in 2009 (18\% of the world population). $98 \%$ of people suffering from food insecurity are from developing countries.

${ }^{36}$ UN-Energy, supra note 3 at 31.
} 
and increases the price of food commodities, making food less available for the poorest. ${ }^{37}$ The problem is particularly dire "when farmers can obtain greater profits by using their land for biofuels than for food." 38 The expression "Feed or Fuel" is often used to express this dilemma. ${ }^{39}$ The debate is often oversimplified since food commodity prices are affected by other factors such as the price of energy. ${ }^{40}$ Furthermore, the development of second generation biofuels may limit the impacts of biofuels on food security. ${ }^{41}$ Regardless, it is important to keep in mind the food security aspect of biofuels when assessing their impacts.

Biofuels can also have negative environmental impacts. Most of these impacts are caused by agricultural pollution. As the agroindustry requires large amount of freshwater, "switching to biofuels could place unsustainable demands on water use". ${ }^{2}$ Large scale agriculture, monocultures and plantations often divert freshwater flow (groundwater, streams, lakes, etc.) from natural or communal uses, thus increasing freshwater demands and contributing to water scarcity problems. For example, the cultivation of corn requires

\footnotetext{
${ }^{37}$ A FAO study shows that biofuels do appear to have a negative impact on global food prices. However it is far from the only cause of high food prices: Alessandro Flammini, Biofuels and the underlying causes of high food prices (Rome: Food and Agriculture Organization, 2008) at 10-16.

${ }^{38}$ Richard L Ottinger, "Biofuels - Potentials, Problems \& Solutions" (2009) 19 Fordham Envtl L Rev 253, at 255 .

${ }^{39}$ UN-Energy, supra note 3 at 31; and Siwa Msangi \& Mandy Ewing, "Food, Feed, or Fuel?" (2008) 9 Geo J Int'l Aff 17.

${ }^{40}$ See FAO, supra note 35; UN-Energy, ibid at 31-34; Msangi \& Ewing, ibid at 21-22; and Paul Armah, Aaron Archer \& Gregory C Phillips, "Drivers Leading to Higher Food Prices: Biofuels are not the Main Factor" in Dwight Tomes, Prakash Lakshmanan \& David Songstad, eds, Biofuels: Global Impact on Renewable Energy, Production Agriculture, and Technological Advancements (New York: Springer, 2011). In the case of food prices, it has been demonstrated that sugar and molasses prices are linked to oil price: UN-Energy, at 34. See FAO, at 9-10 for more on the effect of oil price on agricultural products prices.

${ }^{41}$ UN-Energy, ibid at 33.

${ }^{42}$ Arjen Y Hoekstra, Switching to biofuels could place unsustainable demands on water use, The Guardian, 28 May 2015, online: www.theguardian.com < http://www.theguardian.com/sustainablebusiness/2015/may/28/switching-to-biofuels-would-place-unsustainable-demands-on-water-use $>$.
} 
more than twice the amount of water than petroleum refining. ${ }^{43}$ The cultivation of agricultural feedstocks can also adversely affect water quality through the use of pesticides and fertilizers. ${ }^{44}$ Pesticides can seep into groundwater and nearby streams thus potentially harming local ecosystems and polluting freshwater supplies. Biofuels refining also has specific effects on water quality. For example, vinhoto - a by-product of ethanol production - is known to have negative consequences on water quality. ${ }^{45}$ The use of fertilizers by agroindustry is another major issue. Fertilizers pollute water through eutrophication. This happens when excess fertilizers increase dramatically plant and algal life until all oxygen is drained from the water. For example, fertilizers runoff from the Mississippi River system has caused a large "dead zone" in the Gulf of Mexico where marine life cannot survive. ${ }^{46}$

Another effect biofuels production and agriculture share is the transformation of land in order to increase production and keep up with demands. Lands transformed for agricultural purposes are often forests, grasslands, wetlands and other highly biodiverse ecosystems. This creates problems like deforestation, soil erosion, destruction of carbon sinks, and loss of biodiversity. ${ }^{47}$ For example, the increased demand for biofuels has resulted in an expansion of biofuels feedstocks production in highly biodiverse land in Brazil. ${ }^{48}$ When land conversion happens directly, it is called direct land-use change. Such changes are easier to monitor and to regulate (e.g. prohibiting the conversion of highly

\footnotetext{
${ }^{43}$ Tait et al, supra note 23 at 33.

44 Nicola Colbran \& Asbjorn Eide, "Biofuel, the Environment, and Food Security: A Global Problem Explored Through a Case Study of Indonesia” (2008-2009) 9 Sustainable Dev L \& Pol'y 4 at 7-8.

${ }^{45}$ Ottinger, supra note 38 at 255.

46 Tait et al, supra note 23 at 33-34.

${ }^{47}$ UN-Energy, supra note 3 at 44-45; and Ottinger, supra note 38 at 255-256.

${ }^{48}$ Tait et al, supra note 23 at 36.
} 
biodiverse land into agricultural land). ${ }^{49}$ The problem of land-use becomes more complicated when indirect land-use change (hereafter ILUC) occurs. ILUC is the result of feedstocks production displacing food crops on agricultural land, which in turn creates a demand for more agricultural land to replace the lost food crops. ${ }^{50}$ ILUC causes the same problems as direct land-use change, but ILUC is much more difficult to predict, monitor and regulate. For example, using wheat feedstock from a pre-existing plantation could cause nearby biodiverse and carbon rich grassland to be transformed into a wheat plantation for food to compensate for the reduction in wheat crops. When ILUC impacts are taken into account, the sustainability of biofuels appears uncertain. ${ }^{51}$

Lastly, the GHG emissions savings potential of biofuels is in doubt. As shown above, the biofuels' GHG savings vary significantly. Many biofuels have higher GHG emissions than their fossil fuels counterparts. ${ }^{52}$ The variation is due to the GHG emissions of agricultural production (direct land-use change, fuels for machines and trucks, energy use, etc), transportation, and refining. If the problem was only picking between different feedstocks and methods of production, it could be regulated with relative ease. However, the problem is significantly more complex due to the effects of ILUC. ILUC often results in the release of GHGs in the atmosphere through the destruction of carbon stocks such as forests and wetlands. The carbon stocked in plants and soil is released though either combustion or destruction done in order to open the land for agricultural production. ${ }^{53}$ ILUC effects cannot be avoided, they can only be

\footnotetext{
${ }^{49}$ Annie Webb \& David Coates, Biofuels and Biodiversity, CBD Technical Series No 65 (Montréal: Secretariat of the Convention on Biological Diversity, 2012) at 35.

${ }^{50} \mathrm{Ibid}$, at 38 .

${ }^{51} \mathrm{Ibid}$, at 38-39.

${ }^{52}$ Smaling, supra note 7 at 296-298.

${ }^{53}$ Tait et al, supra note 23 at 31.
} 
mitigated. ${ }^{54}$ The often unaccounted GHG emissions from ILUC can nullify the climate change mitigation potential of biofuels. ${ }^{55}$ In some circumstances ILUC makes biofuels a worse option than fossil fuels, especially when one takes into account the other impacts of biofuels production. According to one study, "[o]ver the first 30 years, GHG emissions from corn bioethanol are projected to be nearly double those from petrol per kilometre driven." ${ }^{, 56}$ If biofuels cannot act as a sustainable replacement to fossil fuels, their utility is in question.

\section{Regulating Biofuels and Sustainability: Research Framework}

Considering the positive and negative aspects of biofuels summarized above, one can wonder if sustainable biofuels production is feasible. State regulation will have to play a role in order to mitigate as much as possible the negative social and environmental impacts of biofuels production. The Renewable Energy Directive is the EU's attempt to promote sustainable biofuels and limit their impacts. This thesis attempts to analyse the EU's response to the biofuels dilemma. In its simplest form, the research question this thesis seeks to answer can be formulated as follows: can the legal mechanism adopted by the EU foster the sustainable production of biofuels? Prima facie, the question may seem straightforward, but many complex issues need to be addressed before being able to accurately answer it. Sustainable development needs to be defined and dissected. What does sustainable development mean in a legal context? What is its legal weight? Sustainable development is also often accompanied by principles relevant to its

\footnotetext{
${ }^{54}$ Webb \& Coates, supra note 49 at 39.

${ }^{55} \mathrm{Ibid}$, at 38 .

56 Tait et al, supra note 23 at 31-32.
} 
interpretation and application. These principles need to be explored in order to create a better framework of analysis. The principles considered in this thesis are the principle of integration (integration of the various economic, social and environmental issues into decision and policy making), inter and intra-generational equity (long-term and shortterm environmental and social impacts), the precautionary principle (management of scientific uncertainty), and the polluter pays principle (economic burden of polluting/environmental measures). These principles were chosen above others for their relevance to the topic of biofuels and to the EU legal framework. Of course other principles are relevant, but these four are, in my view, the broadest and in some cases the core principles of sustainable development, and therefore the most useful for the theoretical framework of this thesis. Secondly, and to complement the principled approach outlined above, this thesis explores the use of lifecycle assessment as a tool to evaluate the alleged sustainability of the EU biofuels regime. Lifecycle assessment is a methodology geared towards analyzing the lifecycle impacts of products. It is highly relevant to biofuels considering the fact that most of the negative impacts of the product arise not from its consumption but from the production of feedstocks. Finally, the boundaries of the EU biofuels legislative scheme need to be defined. The EU has a complex legal regime of environmental, economic and agricultural norms. Selecting which norms will be relevant for our assessment of sustainability is crucial to ensure that this thesis remains relevant without being too broad.

The issues surrounding biofuels are quite complex and there are many ways to approach the problematique. For a legal scholar, two main broad methodologies can be used to answer the research question: qualitative and quantitative methods. Both could 
produce valuable research contributions to the issue of biofuels. The methodology used in this thesis is qualitative in nature considering the breadth of the topic, the research tools of the author, and the timeframe for completing the thesis. In addition, the heavily legislative and principled aspect of this thesis is better suited to qualitative analysis. Qualitative research studies words, images and observable phenomena. It permits the observation of specific problems in detail and with a certain amount of flexibility. ${ }^{57}$ Qualitative research can be quite subjective ${ }^{58}$ which is not necessarily a flaw as long as the bias and values of the researcher are clearly stated. By indicating their own views, the researcher cannot be accused of manipulating the data and conclusions since readers are informed about the possible biases and can draw their own conclusions on the biases' possible impact on the research. In this research, the need for sustainable development is not only important for how the research question is answered; it is also crucial for the very existence of the research question and the creation of a research project on biofuels and sustainable development. The main qualitative approach used is doctrinal analysis. ${ }^{59}$ This thesis focuses on legal texts relevant to EU biofuels production, mainly the 2009 Renewable Energy Directive, the legal concept of sustainable development, and the lifecycle assessment approach. This legal analysis is complemented by data from prior lifecycle assessments of EU biofuels and other relevant sources.

\footnotetext{
${ }^{57}$ Richard Ericson et al, Representing Order: Crime, Law and Justice in the News Media (Toronto: University of Toronto Press, 1991) at 54-58; and Wing Hong Chui, "Quantitative Legal Research" in Mike McConville \& Wing Hong Chui, Research Methods for Law (Edinburgh: Edinburgh University Press, 2007) at 48.

${ }^{58}$ Chui, ibid at $48-49$.

${ }^{59}$ Fink provides a good framework for qualitative doctrinal analysis: "(1) Selecting research questions; (2) Selecting bibliographic or article databases; (3) Choosing search terms; (4) Applying practical screening criteria; (5) Applying methodological screening criteria; (6) Doing the review; and (7) Synthesising the results": Ian Dobinson \& Francis Johns, "Qualitative Legal Research" in Mike McConville \& Wing Hong Chui, Research Methods for Law (Edinburgh: Edinburgh University Press, 2007) at 22-23.
} 
The EU was chosen as a case study mainly for two reasons. Firstly, it started developing and promoting biofuels since at least 1992 and consequently had to develop a legal framework for biofuels. The 2009 Renewable Energy Directive includes a novel provision imposing sustainability criteria for biofuels. Secondly, the EU is one of the three major producers of biofuels and the main producer of biodiesel. ${ }^{60}$ This places the EU as a leader on the international biofuels market which means that its policies have a lot of influence directly and via international trade on other countries' policy choices. One cannot ignore the influence of the EU on the global market, especially when $36 \%$ of feedstocks used for EU biofuels are imported. ${ }^{61}$

Since this thesis comes to the conclusion that the EU biofuels regime is currently not sustainable, the main objective of this thesis is to provide a useful assessment of the flaws of the 2009 Renewable Energy Directive and thus help policy-makers adopt more sustainable biofuels policies. Consequently, the thesis is aimed, in addition to legal and other scholars interested in energy and environmental issues, at decision-makers and others involved in biofuels policy specifically in the EU, but also around the world. Moreover, the thesis, although to a lesser extent, endeavors to show that a sustainable biofuels regime is possible. Additionally, I hope that this research will highlight the importance of an international approach to sustainable development and the usefulness of a lifecycle assessment approach to legal questions.

\footnotetext{
${ }^{60}$ The EU produces half of the world biodiesel. Brazil, the US and the EU produced $90 \%$ of liquid biofuels in 2007: UNEP, supra note 8 at 34. The current EU production capacity for biofuels is not fully utilized and thus the EU has the potential of being an even larger player on the biofuels market: EU, Commission Staff Working Document Accompanying the document Renewable energy progress report, 27 March 2013, $\operatorname{SWD}(2013) 102$ at 14.

${ }^{61}$ See John McCormick \& Jonathan Olsen, The European Union: Politics and Policies, $5^{\text {th }}$ ed (Boulder, CO: Westview Press, 2013) at 10; and EU, Commission, Renewable energy progress report, 27 March 2013, $\operatorname{COM}(2013) 175$ at 11.
} 


\section{Thesis Outline}

This thesis is divided into five chapters. The present chapter was an introduction to the biofuels dilemma and to the objectives of this thesis. The second chapter sets out the theoretical framework of this thesis (Sustainable from Birth to Death: Lifecycle Assessment and Sustainable Development Principles). It defines the concept of sustainable development and its principles as understood in international law. It further summarises the lifecycle assessment methodology, and suggests how this scientific method can guide this thesis' approach to sustainability. The third chapter is a doctrinal analysis of the EU legal framework for biofuels with an emphasis on the 2009 Renewable Energy Directive (The EU's Direction: The Renewable Energy Directive and its Setting). The fourth chapter applies the approach developed in chapter 2 to the legal framework (Shades of Greens: Assessing the Sustainability of EU Biofuels). It assesses the sustainability of the Directive by comparing it to principles of sustainable development and to data on the impacts of biofuels. It further identifies the shortcomings of the EU biofuels regulatory framework. The last chapter concludes the thesis, proposes some recommendations to ameliorate the regime and identifies the next research steps (When Good Intentions Are Not Enough: Recommendations and Conclusion). 


\section{Chapter 2 - Sustainable from Birth to Death: Lifecycle Assessment and Sustainable Development Principles}

\section{Introduction}

The biofuels dilemma is quite complex. The GHG reduction potential of biofuels is great but only if the fuel is produced in a sustainable manner. As mentioned in the previous chapter, the pros and cons of biofuels are numerous. To some the whole venture should be dropped and we should proceed to find other more viable solutions for climate change and energy development. ${ }^{62}$ Many others believe that bioenergy capacity is far too great to ignore and think that there are ways to mitigate the negative effects of biofuels production. ${ }^{63}$ Considering that many states are moving forward with biofuels including the EU and its member states, ${ }^{64}$ it is in our best interest to attempt to enhance the biofuels legal framework and ensure that new generations of bioenergy will have optimal GHG

\footnotetext{
${ }^{62}$ See for example Oxfam, The Hunger Grains, Oxfam briefing paper 161, 2012, online: www.oxfam.org < https://www.oxfam.org/sites/www.oxfam.org/files/file attachments/bp161-the-hunger-grains-170912summ-en 5.pdf >; UN Special Rapporteur on the right to food, Note on the Impacts of the EU Biofuels Policy on the Right to Food, United Nations, Office of the High Commissioner for Human Rights, 23 April 2013, online: www.srfood.org < http://www.srfood.org/fr/special-rapporteur-urges-phase-out-of-eubiofuel-incentives >; Roger Harrabin, Call to abandon biofuels targets, BBC, 21 January 2008, online: www.bbc.co.uk < http://news.bbc.co.uk/2/hi/7199073.stm >; and Letter from 112 Civil Society Organisations, Re: EU biofuels policy comes at an unacceptably high economic, social and environmental cost - time to fix a failed policy, June 2013, online: www.eeb.org < http://www.eeb.org/?LinkServID=7048EFE2-5056-B741-DBC7F4A2A6B6DB96\&showMeta=0\&aa >.

${ }_{63}$ See for example UN-Energy, Sustainable Bioenergy: A Framework for Decision Makers (United Nations, 2007); Ausilio Bauen et al, Bioenergy - A Sustainable and Reliable Energy Source, (Paris: International Energy Agency, 2009); and Jeremy Lawson, European Energy Policy and the Transition to a Low-Carbon Economy, OECD Economics Department Working Papers No 779, (Paris: OECD Publishing, 2010).

${ }^{64}$ EU, Commission, Clean Power for Transport: A European Alternative Fuels Strategy, 24 January 2013, $\operatorname{COM(2013)~17;~EU,~Commission,~Energy~Technologies~and~Innovation,~} 2$ May 2013, COM(2013) 253; United States Department of Energy, Secretary Moniz's remarks on the importance of biofuels to America's clean energy future, 1 August 2013, online : www.energy.gov < http://energy.gov/articles/secretary-monizbiofuels-important-americas-energy-future >; and Office of Energy Efficiency, An Update on Renewable Diesel Infrastructure in Canada, Natural Resources Canada, 14 September 2012, online: www.oee.nrcan.gc.ca < http://oee.nrcan.gc.ca/transportation/alternative-fuels/resources/18237 >.
} 
reduction capacity and minimal negative impacts on the environment and human rights. Sustainable development offers the appropriate guidelines to achieve such goals.

The concept of sustainable development can be a murky one. It is such a broad concept that one can get lost when trying to grasp its meaning and all of its implications. The meaning of sustainability will change depending on the type of law (e.g. municipal law vs. international law) and the topic (e.g. agriculture, energy, biodiversity, fisheries, etc.). In the present case, two aspects of sustainability are useful: the substantive element of sustainable development and its application through the life cycle assessment approach which is particularly pertinent for biofuels. This chapter thus looks at how sustainable development is defined in international law and how it is applicable as a legal principle to the object of this thesis. Furthermore it briefly analyses a few sustainable development principles of particular relevance to biofuels. Finally, it summarises how the lifecycle assessment methodology can inform the assessment of the sustainability of biofuels legislation.

The goal of this chapter is to establish a sustainable development framework that can be used to evaluate the sustainability of the Renewable Energy Directive ${ }^{65}$ and other relevant EU regulations, and to inform the next generation of sustainable biofuels regulations. It lays down the foundation of the core concept of sustainable development used in this thesis and how it can be adapted, through a lifecycle approach, to evaluate the sustainability of the Renewable Energy Directive.

\footnotetext{
${ }^{65}$ EC, Directive 2009/28 of the European Parliament and of the Council of 23 April 2009 on the promotion of the use of energy from renewable sources and amending and subsequently repealing Directives 2001/77/EC and 2003/30/EC, [2009] OJ, L 140/16 [Renewable Energy Directive].
} 


\section{A Legal Story of Sustainable Development}

As we struggle to find solutions to environmental problems, the developing nations are pushing their economic advancement in the hope of ameliorating their situation. The constant pressure on natural resources is already unsustainable and this unsustainability is likely to increase as more states from the global south reach higher level of development. ${ }^{66} \mathrm{We}$ are stuck between a "rock and a hard place" as our desires for a better life, especially regarding the least fortunate of us, and for a more environmentally friendly development often clash. One concept has tried to shift our perception by balancing economic, social and environmental needs. This concept is sustainable development. Not everyone agrees on its exact meaning, on its effectiveness, or on its impact. This means that finding one's way through the concept of sustainable development is not an easy task. This section starts with an overview of the general definitions of sustainable development. It then describes why the concept is a relevant normative framework to analyse the Renewable Energy Directive.

\subsection{What is Sustainable Development?}

Sustainable development can be considered as the new paradigm for international environmental law. ${ }^{67}$ It is a reaction to the unsustainable economic development that fueled the development of the global north; a recognition that human society is part of the broader ecological process. ${ }^{68}$ The concept emerged in the 1980 s as a way to bridge the

\footnotetext{
${ }^{66}$ In 2008 we consumed over 1.5 of our planet's resource capacity: WWF, Living Planet Report 2012 (Gland, CH: World Wildlife Fund, 2012) at 8-9.

${ }^{67}$ Ved P Nanda \& George W Pring, International Environmental Law and Policy for the 21 st Century, $2^{\text {nd }}$ rev ed (Leiden: Martinus Nijhoff, 2013) at 25.

${ }^{68}$ Marie-Claire Cordonier Segger, "Sustainable Development in International Law" in David Armstrong, ed, Routledge Handbook of International Law (New York: Routledge, 2009) at 356 [Cordonier Segger];
} 
views of developed and developing countries on development and environmental protection. ${ }^{69}$ As implied above, there is no one definition of sustainable development. ${ }^{70}$ Many conferences and thinkers have created numerous definitions and some are still being formulated. ${ }^{71}$ However, three of them stand out. The first comes from the Brundtland Report: "Sustainable development is development that meets the needs of the present without compromising the ability of future generations to meet their own needs." ${ }^{, 72}$ This is the most generally accepted definition of sustainable development. ${ }^{73}$ The International Court of Justice made a similarly well-known formulation in the Gabcikovo-Nagymaros case: "[the] need to reconcile economic development with protection of the environment is aptly expressed in the concept of sustainable development." 74 It is the recognition by the international community and international law of the interdependence of environment and development, and of the need to integrate

and Duncan French, International Law and Policy of Sustainable Development (Manchester: Manchester University Press, 2005) at 10 [French].

${ }^{69}$ Marie-Claire Cordonier Segger, "Sustainable Development in International Law" in Hans Christian Bugge \& Christina Voigt, eds, Sustainable Development in International and National Law (Groningen: Europa Law Publishing, 2008) at 92 [Cordonier Segger 2008]. The idea of sustainability is however much more ancient and has deep roots in many cultures: Klaus Bosselmann, The Principle of Sustainability (Surrey, UK: Ashgate, 2008) at Ch 1; and Case concerning the Gabcikovo-Nagymaros Project (Hungary v Slovakia), Judgment, [1997] ICJ Rep 7, per Weeramentry's separate opinion.

${ }^{70}$ Sumudu A Atapattu, Emerging Principles of International Environmental Law (New York: Transnational Publishers, 2006) at 93-94; Andrea Ross, "Modern Interpretations of Sustainable Development" (2009) 36:1 JL \& Soc'y 32 at 35; French, supra note 68 at 12; and Patricia Birnie, Alan Boyle \& Catherine Redgwell, International Law \& the Environment (Oxford: Oxford University Press, 2009) at 54 [Birnie \& Boyle].

${ }^{71}$ Marie-Claire Cordonier Segger \& Ashfaq Khalfan, Sustainable Development Law: Principles, Practices \& Prospects (Oxford: Oxford University Press, 2004) at 3-4; and Birnie \& Boyle, ibid.

${ }^{72}$ World Commission on Environment and Development, Our Common Future, 4 Aug. 1987, UN GA Res., A/42/427 (1987), at Chapter 2, at para 1.

${ }^{73}$ Cordonier Segger, supra note 69 at 356; Nanda \& Pring, supra note 66 at 26; and Atapattu, supra note 70 at 93 .

${ }^{74}$ Gabcikovo-Nagymaros case, supra note 69 at para 140. 
environmental protection into legislation in order to limit the depletion of natural resources. $^{75}$

The third comes from the Johannesburg Plan of Implementation (hereafter the JPI) created at the 2002 World Summit on Sustainable Development (hereafter the WSSD) to implement the Johannesburg Declaration: "Poverty eradication, changing unsustainable patterns of production and consumption and protecting and managing the natural resource base of economic and social development are overarching objectives of, and essential requirements for, sustainable development."76 The Johannesburg instruments focus more on social issues than previous instruments and address topics such as poverty eradication and health. ${ }^{77}$ This is the result of a stronger presence of developing countries at the WSSD who tend to be more concerned about the social development aspect of sustainable development. ${ }^{78}$

These definitions are similar in some ways and in others they are complementary. The first focuses more on future generations and environmental protection while the last focuses on the present and socio-economic development. Put together these definitions

\footnotetext{
${ }^{75}$ French, supra note 68 at 2; Philippe Sands, Principles of International Environmental Law, $2^{\text {nd }}$ ed (Cambridge: Cambridge University Press, 2003) at 253-256 \& 263-266; Birnie \& Boyle, supra note 70 at 55 \& 116-118; Jaye Ellis \& Stepan Wood, "International Environmental Law" in Benjamin Richardson \& Stepan Wood, eds, Environmental Law for Sustainability (Portland, OR: Hart Publishing, 2006) at 375 \& 378-379; and UN, Agenda 21: Programme of Action for Sustainable Development, GA 46th Sess, Agenda Item 21, UN Doc A/Conf.151/26 (1992), at ch 8 [Agenda 21].

${ }^{76} \mathrm{UN}$, Plan of Implementation of the World Summit on Sustainable Development, WSSD 4 September 2002, Johannesburg, UN Doc A/CONF:199/20, at para 2 [JPI]; see also Cordonier Segger, supra note 68 at 358. The outcomes of the WSSD were recently reaffirmed in Rio + 20 United Nations Conference on Sustainable Development, The future we want, 20-22 June 2012, UN Doc A/CONF.216/L.1, at para 16 [Rio + 20].

${ }^{77}$ Cordonier Segger, ibid at 358; Elli Louka, International Environmental Law: Fairness, Effectiveness, and World Order (Cambridge: Cambridge University Press, 2006) at 54; Alexandre Kiss \& Dinah Shelton, Guide to International Environmental Law (Leiden: Martinus Nijhoff, 2007) at 97; French, supra note 68 at 16 \& 22-24; and Cordonier Segger \& Khalfan, supra note 71 at 26-29.

${ }^{78}$ Cordonier Segger, ibid at 358. However, the other instruments of sustainable development, like the Bruntland Report and Agenda 21, did address, to varying degrees, social issues: see Cordonier Segger \& Kahllfan, ibid at 18-22.
} 
form the contemporary idea of sustainable development; which is environmentally and socially responsible development. ${ }^{79}$ Sustainable development can be viewed as the demand of "global long-term economic justice without scarifying the Earth's ecological integrity. ${ }^{80}$ It acts as a framework for decision making. ${ }^{81}$ However, it is important to note that the international community has never adopted one final and universal definition of sustainable development. ${ }^{82}$

\subsection{The Relevance of Sustainable Development}

The legal status and by consequence the legal effects of sustainable development, if any, are matters of debate. There are at least four possible statuses: policy objective, principle, meta-principle, and customary norm. ${ }^{83}$ It is not necessary for the purpose of this thesis to establish which option is more convincing. Sustainable development is a relevant normative framework for the analysis of the Renewable Energy Directive for two reasons. Firstly, as Jutta Brunnée indicated, regardless of the status of many international environmental norms, states seem to make efforts to achieve and consider important the achievement of these goals. ${ }^{84}$ The important thing to keep in mind is that sustainable

\footnotetext{
${ }^{79}$ Duncan French summarizes sustainable development as "a political and socio-economic concept, seeking to reflect an understanding of how to bring together environment, economic and social considerations": Duncan French, "Sustainable Development" in Malgosia Fitzmaurice, David M Ong \& Panos Merkouris, eds, Research Handbook on International Environmental Law (Cheltenham, UK: Edward Elgar Publishing, 2010) at 51 [French 2010].

${ }^{80}$ Bosselmann, supra note 69 at 40 .

${ }^{81}$ Ross, supra note 70 at 51.

${ }^{82}$ Cordonier Segger, supra note 68 at 358; Svitlana Kravchenko, Tareq M R Chowdhury \& Md Jahid Hossain Bhuiyan, "Principles of International Environmental Law" in Shawkat Alam et al, eds, Routledge Handbook of International Environmental Law (New York: Routledge, 2013) at 45 [Kravchenko]; Nanda \& Pring, supra note 66 at 25-26; Birnie \& Boyle, supra note 70 at 54; and Atapattu, supra note 70 at 94.

${ }^{83}$ See Cordonier Segger, ibid at 359; Bosselmann, supra note 69 at 50-58; and Christina Voigt, Sustainable Development as a Principle of International Law (Leiden: Martinus Nijhoff, 2009) at 161.

${ }_{84}$ Jutta Brunnée, "The Stockholm Declaration and the Structure and Processes of International Environmental Law" in Aldo Chircop, Ted MecDorman \& Susan J Rolston, eds, The Future of Ocean
} 
development, regardless of its status, is a goal that the international community and many individual states and organizations, including the EU, are trying to achieve. ${ }^{85}$ The concept has thus acquired a great deal of legitimacy. In the words of Duncan French:

Indeed, whatever its shortcomings, the need for sustainable development remains as great as ever; the enormity of the challenges - both socioeconomic and ecological - makes working towards sustainable development an imperative, both locally and on the global agenda. ${ }^{86}$ [emphasis in the original]

In fact, as indicated by Jutta Brunnée, international environmental law works through horizontal rather than hierarchical processes. Legitimacy can thus have significance impact on compliance. "[I]nternational environmental law furnishes an array of examples that suggest that its ability to operate in this fashion does not necessarily depend on its formal bindingness." 87

Secondly, it is quite clear that one of the goals of the Renewable Energy Directive is sustainable development. Recital 65 of the Preamble specifically states that "[b]iofuel production should be sustainable." The Directive creates sustainability criteria and other obligations to ensure that EU biofuels production is environmental and socially responsible. ${ }^{88}$ The Directive is also a piece of the larger sustainable development goal of the EU. ${ }^{89}$ In fact, the EU has directly incorporated sustainable development as a goal in

Regime Building: Essays in Tribute to Douglas M. Johnston (Leiden: Martinus Nijhoff, 2009) at 58-61; see also Atapattu, supra note 70 at 191; and Binnie \& Boyle, supra note 70 at 127.

${ }_{85}^{85}$ Binnie \& Boyle, ibid at 123-125; Cordonier Segger 2008, supra note 69 at 162; and Atapattu, ibid at 191.

${ }^{86}$ French 2010, supra note 79 at 66.

${ }^{87}$ Brunnée, supra note 84 at 59 .

${ }^{88}$ See Articles $17 \& 23$ of the Renewable Energy Directive, supra note 65.

${ }^{89}$ Ludwig Kramer, "Sustainable Development in EC Law" in Hans Christian Bugge \& Christina Voigt, eds, Sustainable Development in International and National Law (Groningen: Europa Law Publishing, 2008); Luis A Avilès, "Sustainable Development and the Legal Protection of the Environment in Europe" (2011) 12 Sustainable Dev L \& Pol'y 29; and Hans Vedder, "The Treaty of Lisbon and European Environmental Law and Policy" (2010) 22:2 J Envtl L 285. 
the EU treaties. ${ }^{90}$ Is this goal motivated by a sense of legal obligation or simply by virtue? It might be both, but whatever the actual answer is, what matters is that the EU has chosen the path of sustainable development. Using sustainable development as the theoretical framework to analyse the Renewable Energy Directive is sound not only because biofuels represent an excellent example of the intersection of environmental, economic and social policies and because the EU has embraced the concept, but also because it is a guiding concept of international environmental law reflecting important ethical considerations applicable to the whole of the EU biofuels regulatory regime and particularly to the Directive which it permeates. ${ }^{91}$

\section{A Guide for Sustainability: The Principles of Sustainable Development}

The complexity of sustainable development, at least legally, is obvious from its lack of clear definition and status. At a minimum, various international law instruments indicate that sustainable development is based on the interrelation of what the Johannesburg Declaration calls the three pillars of sustainable development: economy,

\footnotetext{
${ }^{90}$ Preamble \& Articles 3(3)\&(5), 6(1) \& 21(2)(d)\&(f) of the Treaty on European Union, 13 December 2007, [2010] OJ, C 83/13; Article 11 of the Treaty on the Functioning of the European Union, 13 December 2007, [2010] OJ, C 83/47 [TFEU]; and Article 37 \& 51 of the Charter of Fundamental Right of the European Union, [2012] OJ, C 326/391.

${ }^{91}$ International law is generally applicable to the EU: Alina Kaczorowska, European Union Law, $3^{\text {rd }}$ ed (New York: Routledge, 2013) at 115; and Koen Lenaerts, Piet Van Nuffel \& Robert Bray, ed, Constitutional Law of the European Union, $2^{\text {nd }}$ ed (London: Sweet \& Maxwell, 2005) at 739-743 \& 754755. How it applies however depends on each case: see Aurel Sari, "The Relationship between Community Law and International Law after Kadi: Did the ECJ Slam the Door on Effective Multilateralism?" in Matthew Happold, ed, International Law in a Multipolar World (London: Routledge, 2011); Gráinne de Búrca, "The European Court of Justice and the International Legal Order after Kadi" (2010) 51:1 Harv Int'l LJ 1; Ramses A Wessel, "Reconsidering the Relationship between International and EU Law: Towards a Content-Based Approach?" in Enzo Cannizzaro, Paolo Palchetti \& Ramses A Wessel, eds, International Law as Law of the European Union (Leiden: Martinus Nijhoff, 2012); and Jan Klabbers, "International Law in Community Law: The Law and Politics of Direct Effect" (2002) 21 YB Eur L 263.
} 
environment, and social justice. ${ }^{92}$ Sustainable development is also governed - or at least guided - by a multitude of international environmental law principles. ${ }^{93}$ The pillars and some of these principles - mainly equity, integration, polluter pays and precaution - can serve in the evaluation and creation of an effective sustainable biofuels regulatory regime. This section identifies some of the principles of sustainable development relevant to biofuels and the Renewable Energy Directive. It is not an exhaustive review and looks only at the principles I consider the most useful in achieving the goal of this thesis. The section surveys the principle of integration, the principle of equity, and to a lesser extent the polluter pays and precautionary principles.

\subsection{The Principle of Integration}

Of the plethora of international environmental law principles some are closer to the core of sustainable development than others. The principle of integration is such a principle. ${ }^{94}$ It is the intersection of the three pillars of sustainable development: economic development, social justice and environmental protection. ${ }^{95}$ French has qualified the integration as the principle that holds the other principles together. ${ }^{96}$ A formulation of the

\footnotetext{
${ }^{2}$ Johannesburg Declaration on Sustainable Development, Report of the WSSD, UNOR, UN Doc A/Conf 199/20, (2002), Resolution 1, at para 5.

${ }^{93}$ Atapattu, supra note 70 at 93-95; Nanda \& Pring, supra note 66 at 29; Ellis \& Wood, supra note 75 at 356 \& 373; Bosselmann, supra note 69 at 58; French, supra note 68 at 53-54; and Philippe Sands \& Jacqueline Peel, Principles of International Environmental Law, 3rd ed (Cambridge: Cambridge University Press, 2012) at 206-217.

${ }^{94}$ Bosselmann, ibid at 61; Birnie \& Boyle, supra note 70 at 116-117; Voigt, supra note 83 at 36; Cordonier Segger \& Khalfan, supra note 71 at 103; French, ibid at 54-55; Atapattu, ibid at 129; and Ellis \& Wood, ibid at 378. Jodoin qualifies integration as the most important sustainable development principles: Sébastien Jodoin, The Principle of Integration and Interrelationship in Relation to Human Rights and Social, Economic and Environmental Objectives, CISDL Legal Working Paper (Montreal: Centre for International Sustainable Development Law, 2005) at 1.

${ }^{95}$ Cordonier Segger \& Khalfan, ibid at 103; Atapattu, ibid at 131-132 \& 194-195; and Jean-Maurice Arbour \& Sophie Lavallée, Droit international de l'environnement (Cowansville, QC: Éditions Yvon Blais, 2006) at 73-80.

${ }^{96}$ French 2010, supra note 79 at 59; see also Voigt, supra note 83 at 37; and Jodoin, supra note 94 at 2.
} 
principle is found in the Rio Declaration: "In order to achieve sustainable development, environmental protection must constitute an integral part of the development process and cannot be considered in isolation from it." ${ }^{97}$ This articulation of the principle requires decision-makers to take into account or integrate environmental protection when considering (economic and social) development projects. This is considered the most basic formulation of the principle. ${ }^{98}$

The principle was further considered at the WSSD in 2002. The Johannesburg Declaration indicates that states should "assume a collective responsibility to advance and strengthen the interdependent and mutually reinforcing pillars of sustainable development - economic development, social development and environmental protection - at the local, national, regional and global levels." ${ }^{.99}$ By putting emphasis on the interdependence of the three pillars, the Declaration seeks to point to the fact that economic, environmental and human rights considerations should not compete with each other but should work together as a whole in the implementation of sustainable development. The JPI stresses the importance of integration by indicating that the efforts of states "will also promote the integration of the three components of sustainable development $[\ldots]$ as interdependent and mutually reinforcing pillars."

\footnotetext{
97 Rio Declaration on Environment and Development, annex of the Report of the United Nations Conference on Environment and Development, 3 June 1992, UN Doc A/CONF. 151/26/Rev. I (Vol. I), Annex I, at Principle 4. See also Birnie \& Boyle, supra note 70 at 119; Stockholm Declaration on the Human Environment, 16 June 1972, UNDocA/CONF/48/14/REV.1, at Principle 13; Arbitration regarding the Iron Rhine (Ijzeren Rijn) Railway, Belgium v Netherlands, (2005) Arbitral Award of 24 May 2005, Reports of International Arbitral Awards Vol. XXVII pp 35-125, at paras 59 \& 243; and GabcikovoNagymaros case, supra note 69 at para 140.

${ }^{98}$ French, supra note 68 at 61.

${ }^{99}$ Johannesburg Declaration, supra note 92 at para 5.

${ }^{100}$ JPI, supra note 76 at para 2. See also JPI, at paras 139(b), 144(a), 145, 147(b), $157 \&$ 159; Rio + 20, at para 3; and Cordonier Segger \& Khalfan, supra note 71 at 103-104.
} 
The principle of integration should apply at the conceptual level of policies and laws as well as at their implementation stage, and at all levels of government and in all sectors of society. ${ }^{101}$ The principle can be separated into substantive and procedural integration. Procedural integration, or integrated decision making, requires that the three pillars are truly taken into consideration in the decision making process. ${ }^{102}$ Substantive integration requires that this consideration is reflected in the "end product" and not simply looked at or "balanced" - for example in an environmental assessment - and then disregarded. ${ }^{103}$ It is not a simple weighing exercise. ${ }^{104}$ "[Integration] can be seen as a conceptual shift above existing normative barriers which separate international economic, environmental, and social law."

Integration is not only a key principle of sustainable development; it is also of tremendous importance for the production of sustainable biofuels. One of the main criticisms of contemporary biofuels production is its narrow focus as a partial solution to climate change - and even then sometimes only with regards to certain impacts of biofuels production - without considering other environmental problems and social issues. By ensuring that the legal framework for bioenergy respects integration, we are assured that, if done properly, the production of biofuels from the planting of seeds for

\footnotetext{
${ }^{101}$ French, supra note 68 at 55; James Cameron, "Future Directions in International Environmental Law: Precaution, Integration and Non-state Actors" (1996) 19 Dal LJ 122 at 128; and Article 7.2 of ILA, New Delhi Declaration on Principles of International Law Relating to Sustainable Development (London: International Law Association, 2002); and Rio + 2, supra note 76 at para 63.

${ }^{102}$ Jodoin, supra note 94 at 9.

${ }^{103}$ Cordonier Segger \& Khalfan, supra note 71 at 104; Voigt, supra note 83 at 37; Atapattu, supra note 70 at $130-131$.

104 Bosselmann, supra note 69 at 35-36; and Klaus Bosselmann, "Sustainable development and international environmental law" in Shawkat Alam, eds, Routledge Handbook of International Environmental Law (New York: Routledge, 2013) at 669. Voigt suggests that integration should require that the ecological threshold of our planet be respected: Voigt, ibid at 40.

${ }^{105}$ Voigt, ibid at 38.
} 
feedstocks to the consumption of the fuel will respect social and environmental values to an acceptable minimum, especially when combined with the equity principle.

\subsection{The Principle of Equity}

The principle of equity is another key principle often mentioned in the definitions of sustainable development. ${ }^{106}$ Equity is considered as the social dimension of sustainable development - as equity and fairness are words deeply anchored in social justice - and has two aspects: inter-generational equity and intra-generational equity. ${ }^{107}$ The principle as a whole is expressed in the Rio Declaration: "The right to development must be fulfilled so as to equitably meet developmental and environmental needs of present and future generations."108 The two "sub-equities" are to be considered as a whole since the principle of equity would lose its meaning if equity for one generation was achieved at the expense of another. ${ }^{109}$ Nevertheless, they are analysed separately in this section for ease of comprehension.

Inter-generational equity or the rights of future generation consists of taking into account the long-term impacts of current development on future generations. ${ }^{110}$ The

\footnotetext{
${ }^{106}$ Cordonier Segger \& Khalfan, supra note 71 at 122-123; Atapattu, supra note 70 at 114-115; and Rebecca M Bratspies, "Reconciling the Irreconcilable: Progress Toward Sustainable Development" in Russell A Miller \& Rebecca M Bratspies, Progress in International Law (Leiden: Martinus Nijhoff, 2008) at 826.

${ }_{107}$ Lynda Collins, "Revisiting the Doctrine of Intergenerational Equity in Global Environmental Governance" (2007) 30 Dal LJ 79 at 101-102; Bosselmann, supra note 69 at 59; Ellis \& Wood, supra note 75 at 376; and Cordonier Segger \& Khalfan, supra note 71 at 122-123.

${ }^{108}$ Rio Declaration, supra note 97 at Principle 3.

${ }^{109}$ Cordonier Segger \& Khalfan, ibid at 124; Edith Brown Weiss, "In Fairness to Future Generations and Sustainable Development" (1992) 18:1 American U Int'l L Rev 19 [Brown Weiss]. Some refer to the principle of equity as "environmental justice": Nanda \& Pring, supra note 66 at 33.

${ }_{110}$ Cordonier Segger \& Khalfan, ibid at 123; Ellis \& Wood, supra note 75 at 377-378 and Bosselmann, supra note 69 at 59 .
} 
Brundtland Report's definition of sustainable development aptly embodies the principle.

The principle recognizes two key facts:

(1) human life emerged from, and is dependent upon, the earth's natural resource base, including its ecological processes, and is thus inseparable from environmental conditions; and (2) human beings have a unique capacity to alter the environment upon which life depends. ${ }^{111}$

As the New Delhi Declaration indicates, equity balances the right to development with the right of future humans to enjoy the same level of environmental quality and access to resources as we enjoy today. ${ }^{112}$ It states that

[t]he present generation has a right to use and enjoy the resources of the Earth but is under an obligation to take into account the long-term impact of its activities and to sustain the resource base and the global environment for the benefit of future generations of humankind. 'Benefit' in this context is to be understood in its broadest meaning as including, inter alia, economic, environmental, social and intrinsic benefit. ${ }^{113}$

When linked to integration this means that decision-makers must take into account long term environmental and social impacts of development. ${ }^{114}$

We, the current generation, thus hold the Earth in trust of future generations while benefiting from its resources; a difficult position. ${ }^{115}$ Since future generations are not here to promote their interests, inter-generational equity acts as a fairness mechanism in

\footnotetext{
${ }^{111}$ Kiss \& Shelton, supra note 77 at 106.

${ }^{112}$ See also Stockholm Declaration, supra note 97 at Principle 2; Brown Weiss, supra note 109 at 22-23; and Edith Brown Weiss, "Implementing Intergenerational Equity" in Malgosia Fitzmaurice, David M Ong \& Panos Merkouris, eds, Research Handbook on International Environmental Law (Cheltenham, UK: Edward Elgar Publishing, 2010) at 100-108 [Brown Weiss 2010]. See also the separate opinions of Judge Weeramantry in Case Concerning Maritime Delimitation in the Area Between Greenland and Jan Mayen (Denmark v Norway), [1993] ICJ Rep 38; Request for an Examination of the Situation in Accordance with Paragraph 63 of the Court's Judgment of 20 December 1974 in the Nuclear Tests (New Zealand v France) Case, [1995] ICJ Rep 288; Legality of the Threat or Use of Nuclear Weapons Case, Advisory Opinion, [1996] ICJ Rep 226; and Gabcikovo-Nagymaros case, supra note 69.

${ }^{113}$ New Delhi Declaration, supra note 101 at Article 2.2.

${ }^{114}$ Ellis \& Wood, supra note 75 at 377-378.

115 Brown Weiss, supra note 109 at 20; Collins, supra note 107 at 96-97; Brown Weiss 2010, supra note 112 at 102; Kiss \& Shelton, supra note 77 at 106; and Sands \& Peel, supra note 93 at 209. Principle 1 of the Stockholm Declaration, supra note 97, recognizes "a solemn responsibility to protect and improve the environment for present and future generations".
} 
distancing development from immediate, short term and somewhat egoistical benefits. This could require the perilous exercise of evaluating the needs of future generations; however this task is seemingly impossible. ${ }^{116}$ Consequently, the pragmatic way to approach inter-generational equity is to limit environmental degradation to the maximum and favouring long term solutions and "renewable benefits" (e.g. using renewable energy, using renewable material, building lasting infrastructures, etc.). ${ }^{117}$ It may be conceptually easier to view inter-generational equity as the responsibility or duty of current generations instead of the right of future generations; a duty consisting of a mix of positive obligations (to provide resources to future generations) and negatives ones (to avoid irreparable environmental harm). ${ }^{118}$ Nonetheless, the operationality of intergenerational equity is often viewed as passing the environment on to the next generation in no worse condition than it was received in order to preserve the choice of various options for future generations. ${ }^{119}$

If inter-generational equity is associated with the needs of future generations, intra-generational equity is associated with the needs of today's generation. ${ }^{120}$ The “overriding priority' [of states] should be given to the 'concept of needs', in particular 'the essential needs of the world's poor' as a key component of sustainable

\footnotetext{
${ }^{116}$ Graham Mayeda, "Where Should Johannesburg Take Us - Ethical and Legal Approaches to Sustainable Development in the Context of International Environmental Law" (2004) 15 Colo J Int'l Envtl L \& Pol'y 29 at 42-50 \& 59-63; Atapattu, supra note 70 at 116-118; Birnie \& Boyle, supra note 70 at 120-122; and Bosselmann, supra note 69 at 32-33.

${ }^{117}$ Brown Weiss, supra note 109 at 25-26; and Kiss \& Shelton, supra note 77 at 106 . See also Brown Weiss's three steps implementation of inter-generational equity: Brown Weiss 2010, supra note 112 at 108113.

${ }^{118}$ Collins, supra note 107 at 106.

${ }^{119}$ Kiss \& Shelton, supra note 77 at 106; and Voigt, supra note 83 at 52. See also Stockholm Declaration, supra note 97 at Principles 2, 3, 5 and 6.

${ }^{120}$ Bosselmann, supra note 69 at 59.
} 
development." ${ }^{121}$ The WSSD definition of sustainable development clearly embodies this aspect of the equity principle. Intra-generational equity is naturally interconnected with poverty eradication and remedying serious socio-economic asymmetries. ${ }^{122}$ The theme of poverty eradication has a strong presence in the JPI, the Millennium Development Goals, Agenda 21, and the Rio +20 outcome document. ${ }^{123}$ Intra-generational equity is also rooted in international human rights obligations. ${ }^{124}$

If, according to the principle, each state has a duty to ensure that equity is reached within its population, the duty is also applicable at the international level as indicated by the New Delhi Declaration:

Whilst it is the primary responsibility of the State to aim for conditions of equity within its own population and to ensure, as a minimum, the eradication of poverty, all States which are in a position to do so have a further responsibility, as recognized by the Charter of the United Nations and the Millennium Declaration of the United Nations, to assist States in achieving this objective. ${ }^{125}$

Intra-generational equity recognizes that Indigenous peoples, women, the poor and minority groups are more prone to suffer from environmental degradation and less prone to benefit from the fruits of development. ${ }^{126}$ The first step is thus to evaluate the needs of these specific groups in order to ensure that sustainable development will meet those needs appropriately and equitably, and therefore limit unnecessary development and its potential impact on the environment.

\footnotetext{
${ }^{121}$ Cordonier Segger \& Khalfan, supra note 71 at $123 \& 125$. See also Ellis \& Wood, supra note 75 at 375 376.

${ }^{122}$ Cordonier Segger \& Khalfan, ibid at 125.

${ }^{123}$ Bosselmann, supra note 69 at 59; Cordonier Segger \& Khalfan, ibid at 122-132; and Rio + 20, supra note 76.

${ }^{124}$ Cordonier Segger \& Khalfan, ibid at 123 \& 132; and Atapattu, supra note 70 at 111.

${ }^{125}$ New Delhi Declaration, supra note 101 at Article 2.4. See also Stockholm Declaration, supra note 97 at Principle 11; and French, supra note 68 at 28-29.

${ }^{126}$ Ellis \& Wood, supra note 75 at 377.
} 
Future generations' equitable enjoyment of natural resources depends partly on the fact that these resources are equitably shared today; otherwise only the offspring of the wealthy - mostly in the western world - would benefit from inter-generational equity, which is antithetical to the concept of equity and fairness. ${ }^{127}$ "[I]ntra-generational equity remains pivotal to maintain global acceptance of sustainable development." ${ }^{\text {2128 }}$ In sum, developed nations, as the primary beneficiary of natural resource exploitation, will have to bear a greater portion of the effort needed to respect our duty towards future generations, bringing the two sub-equities into one coherent principle.

When applied to the sustainable development of biofuels, the principle of equity entails that the legal regime for bioenergy takes into consideration the current scarce resources and ensures that they are redistributed fairly amongst the current generation and exploited at a pace that permits regeneration of the resources for future needs. In concrete term, the wealth and technology generated by the bioenergy industry cannot only benefit the wealthy, and biofuels production should be mindful of the environmental and social problems it generates. The principle also entails that the developed world will have to take the lead in ensuring the sustainable development of biofuels; meaning that it will be responsible for investing resources into the development of ecologically sound biofuels and for ensuring the worldwide equitable availability of the results of such investment.

\footnotetext{
${ }^{127}$ Atapattu, supra note 70 at $115 \& 178$; French 2010, supra note 79 at 61; Mayeda, supra note 116 at 5456; and Brown Weiss, supra note 109 at 21-22.

${ }^{128}$ French 2010, ibid at 60-61. See also Bill Hopwood, Mary Mellor \& Geoff O’Brien, "Sustainable development: mapping different approaches" (2005) 13 Sust Dev 38 at 45; W M Adams "Green Development Theory? Environmentalism and sustainable development" in Jonathan Crush, ed, Power of Development, (London: Routledge, 1995) at 90-91; and Subhabrata Bobby Banerjee, "Who Sustains Whose Development? Sustainable Development and the Reinvention of Nature" (2003) 24:1 Organization Studies 143.
} 


\subsection{The Polluter Pays Principle and the Precautionary Principle}

Unlike the integration and equity principles, the polluter pays and the precautionary principles are more practical and less conceptual in nature. ${ }^{129}$ The polluter pays principle applies in circumstances where environmental harm has already occurred and in natural resources management. The polluter pays principle is found in Principle 16 of the Rio Declaration:

National authorities should endeavour to promote the internalization of environmental costs and the use of economic instruments, taking into account the approach that the polluter should, in principle, bear the cost of pollution, with due regard to the public interest and without distorting international trade and investment. ${ }^{130}$

In economic terms, the polluter pay principle requires polluters to internalize the costs generated by their pollution (referred to as externalities). ${ }^{131}$ The principle encourages the "rational use of scarce environmental resources". ${ }^{132}$ In the context of resource exploitation, the principle is sometimes described as the "user pays" approach to

\footnotetext{
${ }^{129}$ Nicolas de Sadeleer, Environmental Principles: From Political Slogans to Legal Rules (Oxford: Oxford University Press, 2002) at 6-7.

${ }^{130}$ See also Article 191(2) of the TFEU, supra note 90; Preamble of the Stockholm Convention on Persistent Organic Pollutants, 22 May 2001, 2256 UNTS 119; Preamble of the International Convention on Oil Pollution, Preparedness, Response and Cooperation, 30 November 1990, 30 ILM 733; Article 2(2)(b) of the Convention for the Protection of the Marine Environment of the North-East Atlantic, 22 September 1992, 32 ILM 1069; Article 5(b) of the Protocol on Water and Health to the 1992 Convention on the Protection and Use of Transboundary Watercourses and International Lakes, 17 June 1999, 2331 UNTS 202; Article 3(4) of the Convention on the Protection of the Marine Environment of the Baltic Sea Area, 9 April 1992, 13 ILM 546; Preamble of the Convention on the Transboundary Effects of Industrial Accidents, 18 March 1992, 32 ILM 1330; JPI, supra note 76 at paras 15(b) \& 19(b); EC, Commission Decision 1999/272 of 9 December 1998 on the measure planned by Austria for the clean-up of the Kiener Deponie Bachmanning landfill, [1999] OJ, L 109/51; and EEC, Council Recommendation 75/436/EURATOM, ECSC, EEC of 3 March 1975, [1987] OJ, L 169/1, Annex at para 2; US - Taxes on Petroleum and Certain Imported Substances (1987), GATT Doc L/6175, BISD 34S/136, at para 5.2.5; Syndicat national des fabricants raffineurs d'huile de graissage et al v Groupement d'intérêt économique "Inter-Huiles" et al, C-172/82, [1983] ECR 555; and Atapattu, supra note 70 at 464-469.

${ }^{131}$ de Sadeleer, supra note 129 at 22.

${ }^{132}$ OECD Council Recommendation C(72)128 (1972), 14 ILM 236 (1975). See also Kiss \& Shelton, supra note 77 at 95 .
} 
acknowledge the environmental consequences of natural resources consumption. ${ }^{133}$ Put simply, the principle implies that the costs associated with pollution and environmental degradation should be assumed by those responsible for it and not by society as a whole. ${ }^{134}$ States should not assist polluters in bearing the cost of their pollution or of the exploitation of natural resources. ${ }^{135}$ It is however less clear how exactly the principle would apply to government subsidies of polluting activities or industries and to the cost of decontamination, clean-up and reinstatement. ${ }^{136}$ Lastly, while the polluter pays principle deals chiefly with ex post facto pollution, it still has a preventive effect by putting a price on pollution. ${ }^{137}$

If polluter pays principle can be viewed as a "downstream" approach, the precautionary principle would be the "upstream" approach. The precautionary principle is a tool for risk management. ${ }^{138}$ Its goal is to prevent rather than repair environmental damages. ${ }^{139}$ The principle is aptly expressed in Principle 15 of the Rio Declaration:

In order to protect the environment, the precautionary approach shall be widely applied by States according to their capabilities. Where there are

\footnotetext{
${ }^{133}$ Charles S Pearson, “Testing the System: GATT + PPP = ?” (1994) 27 Cornell Int'l L J 553; Benjamin J Richardson, "Economic Instruments in UK Environmental Law Reform: Is the UK Government Sending the Right Signals" (2001) 3 Eur JL Reform 431; de Sadeleer, supra note 129 at 43; and OECD Council Recommendation C(90) 177 (1991) Concerning the Use of Economic Instruments in Environmental Policy. ${ }^{134}$ Atapattu, supra note 70 at 445; de Sadeleer, ibid at 45-50; and Kravchenko, supra note 82 at 51.

135 Priscilla Schwartz, "The Polluter-pays Principle" in Malgosia Fitzmaurice, David M Ong \& Panos Merkouris, eds, Research Handbook on International Environmental Law (Cheltenham, UK: Edward Elgar Publishing, 2010) at 244.

136 Sands \& Peel, supra note 93 at 228-229 \& 232-233; de Sadeleer, supra note 129 at 43-45; and Kravchenko, supra note 82 at 53. See also Schwartz, ibid at 248-249.

${ }^{137}$ Schwartz, ibid at 246-247; and de Sadeleer, ibid at 37.

138 Marco Martuzzi \& Joel A Tickner, eds, Precautionary Principle: protecting public health, the environment and the future of our children (Copenhagen: World Health Organization - Europe, 2004) at 21-22; Stephanie Joan Mead, "The Precautionary Principle: A Discussion of the Principle's Meaning and Status in an Attempt to Further Define and Understand the Principle" (2004) 8 NZ J Envtl L 137 at 146 ; Birnie \& Boyle, supra note 70 at 164; Atapattu, supra note 70 at 214-215; and New Delhi Declaration, supra note 101 at Article 4.3.

${ }^{139}$ Agenda 21, supra note 75 at para 17.21; Kravchenko, supra note 82 at 49; Arie Trouwborst, Evolution and Status of the Precautionary Principle in International Law (The Hague: Kluwer Law International, 2002) at 10-11; and Mead, ibid at 151.
} 
threats of serious or irreversible damage, lack of full scientific certainty shall not be used as a reason for postponing cost-effective measures to prevent environmental degradation. ${ }^{140}$

The principle requires that the proponent of a project (government, corporation or otherwise) prove that their project is environmentally sound as opposed to the opponents proving that a project would cause serious damage to the environment. ${ }^{141}$ When scientific evidence is inconclusive (often referred to as scientific uncertainty), precaution dictates that pollution prevention should prevail over other considerations. ${ }^{142}$ Scientific uncertainty includes "conceptual uncertainty or shortcomings in our understanding of causation, as well as limitations in our ability to sample and take measurements, or

\footnotetext{
${ }^{140}$ See also Article 191(2) of the TFEU, supra note 90; Preamble of the Montreal Protocol on Substances that Deplete the Ozone Layer, 16 September 1987, 1522 UNTS 3; Article 3(3) of the United Nations Framework Convention on Climate Change, 9 May 1992, 1771 UNTS 107; Preamble of the Convention on Biological Diversity, 5 June 1992, 1760 UNTS 79; Preamble \& Article 1 of the Cartagena Protocol on Biosafety, 29 January 2000, 2226 UNTS 208; and Preamble \& Article 1 of the Stockholm Convention, supra note 130; Southern Bluefin Tuna Cases (Order), (1999) ITLOS Nos 3\&4, at paras 77, $79 \& 80$, Separate Opinion of Judge Laing at paras 12 to 21, Separate Opinion of Judge Treves at paras 8-9, and 11, and Separate Opinion of Ad Hoc Judge Shearer; The Queen v Ministry of Agriculture, Fisheries and Food, et al, C-157/96, [1998] ECR I-2211; United Kingdom v Commission, C-180/96, [1998] ECR I-02265; Waddenvereniging and Vogelsbeschermingvereniging $v$ Staatssecretaris van Landbouw, Natuurbeheer en Visserij, C-127/02, [2004] ECR I-7405; EC, Communication from the Commission on the precautionary principle, 2 February 2000, COM(2000) 1; EC, Council Resolution on the Precautionary Principle, Annex III of the European Council's Nice proceedings, 7-10 December 2000; Rio Declaration, supra note 97 at Principle 15; Atapattu, supra note 70 at 234-265; and Nicolas de Sadeleer, "The Principles of Prevention and Precaution in International Law: Two Heads of the Same Coin?" in Malgosia Fitzmaurice, David M Ong \& Panos Merkouris, eds, Research Handbook on International Environmental Law (Cheltenham, UK: Edward Elgar Publishing, 2010) at 187-196 [de Sadeleer 2010].

${ }^{141}$ Jamie Benidickson, Environmental Law, $3^{\text {rd }}$ ed (Toronto: Irwin Law, 2008) at 25; Minna Pyhala, Anne Christine \& Hanna Paulomaki, "The Precautionary Principle" in Malgosia Fitzmaurice, David M Ong, \& Panos Merkouris, eds, Research Handbook on International Environmental Law (Cheltenham, UK: Edward Elgar Publishing, 2010) at 213 [Pyhala et al]; Daniel Bodansky, "Deconstructing the Precautionary Principle" in David D Caron, \& Harry N Scheiber, eds, Bringing New Law to Ocean Waters (Leiden: Martinus Nijhoff, 2004) at 390-391; Kravchenko, supra note 82 at 47; Birnie \& Boyle, supra note 70 at 158-159; Sands, supra note 75 at 273; de Sadeleer, supra note 129 at 203-208; Sands \& Peel, supra note 93 at 222-223; Cordonier Segger \& Khalfan, supra note 71 at 144; Atapattu, supra note 70 at 231-233; Nanda \& Pring, supra note 66 at 64; Mead, supra note 138 at 152-157; Christopher Stone, "Is there a Precautionary Principle?" (2001) 31 Environmental Law Reporter 10790 at 10791; and New Delhi Declaration, supra note 101 at Article 4.2(d).

${ }^{142}$ Birnie \& Boyle, ibid at 156-157 \& 159-164; Bodansky, ibid at 386-387; EC Measures Concerning Meat and Meat Products (Hormones) (1998), WT/DS26/AB/R and WT/DS48/AB/R, at paras 120-125; and Pfizer Animal Health SA v Council of the European Union, T-13/99, [2002] ECR II-3305, at para 143.
} 
deficiencies in modelling procedures." ${ }^{\text {"143 }}$ Acknowledging the difficulty of proving beyond a reasonable doubt the negative impacts of certain products, technologies, projects, etc., the precautionary principle demands that decision-makers adopt preventive policies over reactionary ones (associated with the polluter pays principle) in the face of uncertainty. ${ }^{144}$ The principle also prevents regulatory inaction based on the uncertainty of potential environmental harm. ${ }^{145}$ The precautionary principle simply recognizes the fact that science works with probabilities rather than certainty and therefore environmental law should adapt to this fact. ${ }^{146}$ It is however important to note that the extent of the principle - how and when it should applies - remain unsettled. ${ }^{147}$

While the polluter pays and precautionary principles may seem less central to sustainable development than integration and equity, they remain highly relevant in the context of climate change and bioenergy. ${ }^{148}$ Precaution would mandate the adoption of strong regulations in order to limit the impacts of biofuels production, even in the face of uncertain environmental impacts. It would also preclude the approval of new biofuels or bioenergy technologies that have not been proven as safe. ${ }^{149}$ Polluter pays would also

\footnotetext{
${ }^{143}$ Benidickson, supra note 141 at 25. See also de Sadeleer 2010, supra note 140 at 185-186 and Katie Steele, "The Precautionary Principle: A New Approach to Public Decision-making?" (2006) 5 Law, Probability and Risk 19 at 23.

${ }^{144}$ Martuzzi \& Tickner, supra note 138 at 8; Bodansky, supra note 141 at 385; and Sands, supra note 75 at 267.

${ }^{145}$ Trouwborst, supra note 139 at 11; Bodansky, ibid at 383-384; Kravchenko, supra note 82 at 46-47; Ellis \& Wood, supra note 75 at 362; Birnie \& Boyle, supra note 70 at 155-156; Sands, ibid at 269; and Cordonier Segger \& Khalfan, supra note 71 at 152.

${ }^{146}$ Nanda \& Pring, supra note 66 at 63-64; and Bodansky, ibid at 388.

${ }^{147}$ Bodansky, ibid at 381-383; de Sadeleer 2010, supra note 129 at 184-185; Kravchenko, supra note 82 at 49; Pyhala et al, supra note 141 at 211-212 \& 217; Atapattu, supra note 70 at 210-211; Birnie \& Boyle, supra note 70 at 155; Sands \& Peel, supra note 93 at 218 \& 222; Ellis \& Wood, supra note 75 at 362-363; de Sadeleer, supra note 129 at 156-168; and Mead, supra note 138 at 144.

${ }^{148}$ See Atapattu, ibid at 277-281 \& 477-480; Steele, supra note 143 at 24; and Schwarz, supra note 135 at 256.

${ }^{149}$ It could also mandate the use of cleaner energy sources when available and reserve the use of biofuels for situations where such energy sources are unavailable: see Steele, ibid at 21.
} 
encourage the sustainable development of biofuels in favouring so-called clean fuels over dirty ones whether they are fossil fuels or other biofuels. Furthermore, when applied to tax law polluter pays can be a powerful eco-economic stimulus. Additionally, both principles are specifically mentioned in the Treaty on the Functioning of the European Union. $^{150}$

\section{Lifecycle Assessment and Law: Adapting the Methodology for}

\section{Legislative Schemes}

The concept of sustainable development and its related principles are instructive in formulating a theory of sustainability. As much as theories and concepts help us understand a particular issue, they remain at the abstract level and can be of little practical use without the proper methodology or approach. ${ }^{151}$ A common method to measure the sustainability of biofuels is lifecycle assessment. ${ }^{152}$ It is in fact used by the Renewable Energy Directive to measure GHG emissions of biofuels. This method might be suited for evaluating particular indicia related to the production of biofuels, but it is not necessarily designed to measure the sustainability of a legislative framework. In this section I try to remedy this methodological hurdle by adapting lifecycle assessment to the

\footnotetext{
${ }^{150}$ Article 191(2) of the TFEU, supra note 90.

${ }^{151}$ See for example Bernard Lahire, "Nécessité théorique et obligations empiriques" (2006) 27:1 Revue du MAUSS 444. Nevertheless it is important to stress the value of establishing a theoretical background before engaging in the application of a methodology, especially when such a methodology is geared towards measurement. In the end if a piece of legislation or a policy is evaluated solely on the basis of numbers - in this case the amount of GHGs produced, the amount of pesticide use, etc. - we often only look at the inputs (resources used) and outputs (the end results) without understanding the bigger picture (values, principles, ethics, normativity, etc.) and its impact on the various actors (farmers, corporations, policy-makers, consumers, etc.) creating the so called black box, a vacuum of knowledge on the how $\mathrm{X}$ results were achieved with Y resources: Nicoletta Stame, "Theory-based Evaluation and Types of Complexity" (2004) 10:1 Evaluation 58.

${ }^{152}$ See for example Eric D Larson, “A review of life-cycle analysis studies on liquid biofuel systems for the transport sector" (2006) 10:2 Energy for Sustainable Development 109.
} 
need of this thesis. This section first briefly summarises what lifecycle assessment is. It ends in adapting the method with the help of sustainable development principles into an approach suitable for the purpose of evaluating the sustainability of the Renewable Energy Directive.

\subsection{From Cradle to Grave: Lifecycle Assessment}

Lifecycle assessment (often referred to as LCA), also known as lifecycle analysis, is a tool used to measure "cradle to grave" impacts, traditionally environmental and health impacts, of goods or services (often referred to as "products"). ${ }^{153}$ The International Organization for Standardization (ISO) defines lifecycle assessment as the "compilation and evaluation of the inputs, outputs and the potential environmental impacts of a product system throughout its life cycle."154 The so-called lifecycle refers to "consecutive and interlinked stages of a product system, from raw material acquisition or generation from natural resources to final disposal." 155 It should take into account the effects of all products necessary in the fabrication, maintenance and the use of the assessed product

\footnotetext{
${ }^{153}$ Allan Astrup Jensen et al, Life Cycle Assessment - A guide to approaches, experiences and information sources, Environmental Issues Series no 6 (Copenhagen: European Environment Agency, 1997) at 53-54; and Wayne Trusty, The Environmental Side of Sustainability: Using Life Cycle Assessment to Assess True Performance, National Research Council Canada, Institute for Research in Construction, NRCC-48691, 2006 at $1-2$.

${ }^{154}$ International Organization for Standardization, Environmental management - Life cycle assessment Principles and framework, ISO 14040-2006, $2^{\text {nd }}$ ed (Geneva: ISO, 2006) at para 3.2 [ISO 14040]; see also Reinout Heijungs \& Jeroen B Guinée, "An Overview of the Life Cycle Assessment Method - Past, Present, and Future", in Mary Ann Curran, ed, Life Cycle Assessment Handbook: A Guide for Environmentally Sustainable Products (Beverly, MA: Scrivener Publishing, 2012) at 15.

${ }^{155}$ ISO 14040, ibid at para 3.1. See also Trusty, supra note 153 at 2.
} 
(product system). ${ }^{156}$ For bioenergy this means the full feedstock-to-fuel-consumption pathway. ${ }^{157}$

A lifecycle assessment is usually done in three steps: (1) "compiling an inventory of relevant energy and material inputs and environmental releases"; (2) "evaluating the potential environmental impacts associated with identified inputs and releases"; and (3) "interpreting the results to help decision-makers make a more informed decision." "158 Methodologically speaking, lifecycle assessments require defining the product, establishing the scope of the assessment (goals, limitations, assumptions, quality of data, functional unit, system boundary, etc.), creating an inventory (data collection), assessing the impacts, and finally interpreting the results. ${ }^{159}$ Selection of a functional unit is crucial as it provides the reference unit used to measure impacts (e.g. one kilojoule as the functional unit to compare GHG emissions of corn bioethanol and gasoline). ${ }^{160}$ Another vital step is setting a system boundary; that is, to determine what outputs and inputs will be measured and how. ${ }^{161}$ Each of these steps depends on the result of the previous one; the methodology is thus iterative and depends on transparency for proper

\footnotetext{
${ }^{156}$ Trusty, ibid at 2 .

${ }^{157}$ S Keam \& Nadine McCormick, Implementing Sustainable Bioenergy Production - A Compilation of Tools and Approaches (Gland, CH: IUCN, 2008) at 10.

${ }_{158}$ Scientific Applications International Corporation, Life cycle assessment: Principles and Practice (Cincinnati: Environmental Protection Agency, 2006) at 2 [SAIC].

159 SAIC, ibid at 2; and ISO 14040, supra note 154 at para 4.2.1; International Organization for Standardization, Environmental management - Life cycle assessment - Requirements and guidelines, ISO 14044-2006 (Geneva: ISO, 2006) at paras 4.2 \& 4.3 [ISO 14044]; Heijungs \& Guinée, supra note 154 at 17.

${ }^{160}$ ISO 14044 , ibid at para 4.2.3.2.

${ }^{161} \mathrm{Ibid}$ at para 4.2.3.3.
} 
interpretation. ${ }^{162}$ There is, however, no single method for conducting a lifecycle assessment. $^{163}$

The lifecycle assessment of bioenergy covers the production of the necessary feedstocks (usually the cultivation and/or harvest of biomass), transportation of feedstocks to a refinery, the transformation of feedstocks in bioenergy, the distribution of the bioenergy and its final consumption; which includes evaluating land-use, energy consumption, water consumption, pesticide and herbicide use, biodiversity loss, GHG emissions, etc. ${ }^{164}$ Socioeconomic impacts are sometimes included in lifecycle assessment models, but are typically outside the scope of this method. ${ }^{165}$ Most models for biofuels assessment are usually built to measure GHG impacts.

Like all methodologies, lifecycle assessments have some shortcomings. Firstly, lifecycle assessments are data-intensive and the quality of the results depends heavily on the quality of the data. ${ }^{166}$ Furthermore, the availability of data can significantly impact the quality of the results. ${ }^{167}$ In interpreting lifecycle assessment results it is crucial to properly weigh these results and conclusions in accordance with the quality and availability of the data. For example, a study may not include GHGs produced through ILUC and thus should be considered less reliable. Secondly, lifecycle assessments were developed to compare products and are not especially useful when there is no

\footnotetext{
${ }^{162}$ ISO 14040 , supra note 154 at paras 4.1.5 \& 4.1.6.

${ }^{163}$ Ibid at para $4.3 \mathrm{~g}$ ).

${ }^{164}$ Uwe R Fritsche et al, Bioenergy Environmental Impact Analysis (BIAS): Analytical Framework, FAO Environment and Natural Resources Management Series No 46 (Rome: Food and Agriculture Organisation, 2010) at 3.

${ }^{165}$ Keam \& McCormick, supra note 157 at 10; and ISO 14040, supra note 154 at para 4.1.3.

${ }^{166}$ Fritsche et al, supra note 164 at 3; and Daniel M Kammen et al, Energy and Greenhouse Impacts of Biofuels: A Framework for Analysis, UC Berkeley Transportation Sustainability Research Center, Institute of Transportation Studies (Berkeley: UC Berkley, 2008) at 9-10.

${ }^{167}$ SAIC, supra note 158 at 5.
} 
comparator. ${ }^{168}$ This limitation is of less importance for biofuels since they can be compared to fossil fuels or amongst themselves.

\subsection{A Principled Approach: Lifecycle Assessment and Legislation}

Lifecycle assessment is not only used as a method but also a policy framework to inform decision-makers on environmental impacts of available policy options. ${ }^{169}$ In fact lifecycle assessment methodologies were originally developed to create tools that would help decision-makers distinguish between different products based on their environmental effects. ${ }^{170}$ The methodologies have been found very useful to compare different types of biofuels, to create benchmarks for the industry, to certify biofuels, and to measure compliance with various standards. ${ }^{171}$ Governments have used lifecycle assessments to help them make a variety of policy decisions. They are usually performed to determine whether the benefits of a policy are worth its implementation (preimplementation evaluation), and to determine whether a certain program is performing as desired or to measure the outcomes of a policy (post-implementation evaluation). ${ }^{172}$ Lifecycle assessments can be performed at the conceptual level to determine the general viability, or in our case the sustainability, of a product or a policy. ${ }^{173}$ This determination is, however, limited by its reliance on pre-existing literature and thus is circumscribed by this literature's positive and negative aspects. This thesis is in part a modified conceptual lifecycle assessment. It relies on lifecycle assessment data to assess the sustainability of

\footnotetext{
${ }^{168}$ Fritsche et al, supra note 164 at 3.

${ }^{169}$ Kammen et al, supra note 166 at 6; and SIAC, supra note 158 at 3.

${ }^{170}$ Jensen et al, supra note 153 at 29; and Gjalt Huppes \& Mary Ann Curran, "Environmental Life Cycle Assessment: Background and Perspective", in Mary Ann Curran, ed, Life Cycle Assessment Handbook: A Guide for Environmentally Sustainable Products (Beverly, MA: Scrivener Publishing, 2012) at 3-4.

${ }^{171}$ Keam \& McCormick, supra note 157 at 10.

${ }^{172}$ Huppes \& Curran, supra note 170 at 6.

${ }^{173}$ Jensen et al, supra note 153 at 30.
} 
EU biofuels regulation. The approach of this thesis is thus informed both by the lifecycle assessment methodology and by the sustainable development principles identified above. This sub-section explains this principled lifecycle assessment approach.

The first step is to define the goal and the scope of the lifecycle assessment. The goal can be found in the introduction of this thesis. It can be summarized as assessing the Renewable Energy Directive and its framework to determine if it can ensure the sustainability, as defined through international sustainable development principles, of biofuels production in the EU. The scope of the assessment is limited to a conceptual analysis of the sustainability of EU biofuels. It relies on pre-existing studies measuring the various negative and positive impacts of biofuels production in the EU and in certain countries linked to the EU via feedstocks or biofuels trade. Impacts will be divided in two categories: environmental impacts and social impacts. Environmental impacts will cover specifically GHG emissions, land-use, biodiversity and water quality. Social impacts will cover labour and employment issues, food security, and economic considerations. Environmental impacts will be analysed in more detail than social impacts since lifecycle assessments are generally not built to measure the latter.

One of the key elements of a lifecycle assessment is the comparison of the product's performance to a comparator. The comparator is crucial as lifecycle assessments are not designed to tell if a product is sustainable, but instead indicate if "product $\mathrm{X}$ is 'more sustainable' or 'more environmentally friendly' than product $\mathrm{Y}$, or that the use phase is the 'least sustainable' or 'least environmentally friendly' part of the 
life cycle for product Z."174 For bioenergy, this comparator is often either the traditional energy source used which bioenergy seeks to replace (e.g. gasoline, diesel, nuclear power plant, coal power plant, etc.) or another source of bioenergy when comparing different types of bioenergy (e.g. palm oil biodiesel compared to algae biodiesel). This thesis relies on both comparators. Most of the data used and in fact the Renewable Energy Directive itself rely on biofuels/fossil fuels comparisons. This thesis also compares the impacts of biofuels from each of the three generations.

The assessment phase of the lifecycle approach to sustainability will be divided in two. Firstly, I will analyse the integration of the three pillars of sustainable development by the Directive and its framework. This can be accomplished by looking at what lifecycle environmental, economic and social impacts are taken into consideration by the scheme to ensure the sustainability of biofuels and what weight is given to each (soft vs hard obligations, and their scope). Lifecycle impacts that should be considered in a sustainable biofuels regulatory scheme are GHG emissions, changes in land-use, agricultural pollution, food security, labour and property rights, and economic incentives (e.g. taxes and subsidies).

Secondly, each impact will be interpreted in light of the equity principle. This is achieved by determining how fairly the impacts are distributed through time (intergenerational) and space (intra-generational). In other words, I will examine to what extent the legislative scheme takes into account long-term socio-economic and environmental impacts. Data compiled in studies on EU biofuels will be used to help determine the effectiveness of the legislative measures in ensuring inter and intra-generational equity.

\footnotetext{
${ }^{174}$ Heijungs \& Guinée, supra note 154 at 18.
} 
The focus will thus be on the potential lifecycle impacts of biofuels produced under the regime of the Renewable Energy Directive. As a complement, economic impacts will also be measured against the polluter pays principle to determine who bears the costs of biofuels impacts. Particular attention will be paid to economic incentives related to biofuels.

Additionally, the precautionary principle will be used to analyse the scheme's management of scientific uncertainties and its associated environmental risks. Precaution is also a helpful tool to pick between two or more possible interpretations of provisions or data, and between conflicting data. When such uncertainties arise, especially considering the controversial nature and potential impacts of biofuels, the option that favours environmental protection should be preferred.

This principled lifecycle assessment approach thus uses the principles of sustainable development as barometers or standards against which the Renewable Energy Directive and other relevant legislation can be assessed, and thus provide a way to draw reasonable conclusions on the legislative scheme's sustainability, including identifying its shortcomings.

\section{Conclusion}

Sustainable development is an important concept of international environmental law. Its goal is to ensure that economic development takes into consideration environmental protection and social justice. Regardless of its legal weight, sustainable development is pursued by most states, especially the EU. In fact sustainability is an 
important part of the Renewable Energy Directive. The concept of sustainable development also interacts with narrower principles of sustainable development. They can provide guidance in the interpretation and analysis of the EU biofuels regulatory regime. The principles of integration, equity, polluter pays and precaution are especially relevant to the issues posed by "sustainable" regulation of biofuels.

This theoretical framework will be put into application through an adapted principled lifecycle assessment approach. Such an approach, based on a comparison of impacts of different products through their lifecycle, is particularly apt at assessing biofuels considering that their environmental and social impacts are distributed throughout their lifecycle. The principles will serve as the normative framework guiding the conceptual assessment of the Directive and its legal framework. This approach is based both on the relevant legislative texts and on data from lifecycle assessment studies of biofuels in the EU and relevant states. The next chapter proceeds with a doctrinal analysis of the Renewable Energy Directive and other relevant legislation, the object of the principled lifecycle assessment. 


\section{Chapter 3 - The EU's Direction: The Renewable Energy Directive and Its Setting}

\section{Introduction}

Some overview of the EU "mechanics" is warranted before delving deeper within the depths of EU biofuel regulations. ${ }^{175}$ The nature of the EU as an institution is complex and unique: a hybrid between a state and an international organization. ${ }^{176}$ The institution has changed considerably from a common market for coal and steel in 1951 of 6 members to a supra-national organisation of 28 members with broad powers and a unified legal personality. ${ }^{177}$ Understanding how the EU political system works is also crucial to understand the limits of its power and thus what can be achieved in the future to improve the current situation. Of specific interest is the evolving role of the EU in environmental law. This role has greatly increased since the 1970s when member states unanimously agreed to put environmental protection on the agenda. ${ }^{178}$ With various treaty amendments, especially those of the 1986 Single European Act, ${ }^{179}$ and with the help of

\footnotetext{
${ }^{175}$ See Christian Calliess \& Christian Hey, "Renewable Energy Policy in the EU: A Contribution to Meet International Climate Protection Goals?” (2013) 88 Berliner Online-Beiträge zum Europarecht 1 at 1.

${ }^{176}$ The EU treaties do not define the nature of the Union. The EU mixes intergovernmental, supranational and confederal governance structures: Nigel Foster, Foster on EU Law, $2^{\text {nd }}$ ed (Oxford: Oxford University Press, 2009) at 16; and John McCormick and Jonathan Olsen, The European Union: Politics and Policies, $5^{\text {th }}$ ed (Boulder, CO: Westview Press, 2013) at 16. See also Van Gend en Loos v Nederlandse Administratie der Belastingen, C-26/62, [1963] ECR 1.

${ }^{177}$ Article 47 of Treaty on European Union, 13 December 2007, [2010] OJ, C 83/13 [TEU]; Foster, ibid at 44-45; and Deirdre Curtin, Executive Power of the European Union: Law, Practices, and the Living Constitution (Oxford: Oxford University Press, 2009) at 14. See Alina Kaczorowska, European Union Law, $3^{\text {rd }}$ ed (New York: Routledge, 2013) at 2-36 for the history of the EU.

${ }^{178}$ Ingmar von Homeyer, "The Evolution of EU Environmental Governance", in Joanne Scott, ed, Environmental Protection: European Law and Governance (Oxford: Oxford University Press, 2009) at 2.

${ }^{179}$ The Single European Act, 17 February 1986, [1987] OJ, L 169. The treaty established the EU's first environmental provisions: see Peter G G Davies, European Union Environmental Law: An Introduction to Key Selected Issues (Burlington, VT: Ashgate Publishing, 2004) at 6; and Cinnamon Piñon Carlame, Climate Change Law and Policy: EU and US Perspectives (Oxford: Oxford University Press, 2010) at 155. Before the amendments, the EU could rely, however, on its residual power to adopt binding environmental
} 
the European Court of Justice (hereafter the ECJ), the EU was able to adopt a large body of environmental legislation, including the 2009 Renewable Energy Directive. ${ }^{180}$ The most recent treaty, the Lisbon Treaty, further expanded the role of the EU in environmental law, with specific reference to climate change, and enhanced its capacity regarding energy policy. ${ }^{181}$

Armed with this environmental mandate, the EU became a leader in climate change mitigation. ${ }^{182}$ The Renewable Energy Directive is but one piece of the EU climate change strategy. ${ }^{183}$ The Directive interacts with many other legislation and policies. It is therefore necessary to look at the broader picture to understand and analyse properly the EU regulatory framework for biofuels. Consequently, this chapter establishes the legislative framework of the Renewable Energy Directive assessed in this thesis. It begins with a summary of the EU's current institutional and legal framework and of its environmental competences. It then concentrates on the Directive itself by looking at its past (the steps that lead to its adoption) and its present (its provisions and amendments). It finishes by looking at other relevant EU legislation concerning taxation, agriculture and energy. Overall, I provide in this chapter a description of the EU biofuels regulatory

measures: Articles 100 \& 235 of the Treaty establishing the European Economic Community, 25 March 1957, 298 UNTS 11; Commission v Italy, C-92/79, [1980] ECR 1115; Procureur de la République v $A D B H U$, C-240/83, [1985] ECR 531; and von Homeyer, supra note 178 at 8.

180 Maria Lee, EU Environmental Law: Challenges, Change and Decision-Making (Oxford: Hart Publishing, 2005) at 16; and EC, Directive 2009/28 of the European Parliament and of the Council of 23 April 2009 on the promotion of the use of energy from renewable sources and amending and subsequently repealing Directives 2001/77/EC and 2003/30/EC, [2009] OJ, L 140/16 [Renewable Energy Directive].

${ }^{181}$ Carlame, supra note 179 at 157-158; and Treaty of Lisbon amending the Treaty on European Union and the Treaty establishing the European Community, 13 December 2007, [2007] OJ, C 306/01.

${ }^{182}$ See Sebastian Oberthür \& Claire Roche Kelly, "EU Leadership in International Climate Policy: Achievements and Challenges" (2008) 43:3 The International Spectator: Italian Journal of International Affairs 35

${ }^{183}$ See Preamble at Recital 1 of the Renewable Energy Directive, supra note 180. 
framework (the Directive and other relevant legislative provisions) that is assessed in the next chapter using the principled lifecycle assessment approach previously established.

\section{A Peculiar Type of Law: Background on the EU Legal Framework}

The EU is the result of post-World War II European economic integration. ${ }^{184}$ This integration created a common market and common policies on a broad range of topics. ${ }^{185}$ The Treaty on European Union (hereafter the TEU) and the Treaty on the Functioning of the European Union (hereafter the TFEU) establish the structure, jurisdiction and legislative procedure of the EU. ${ }^{186}$ This section first summarizes the current EU legislative procedure and the nature of EU legislative acts. It then offers a closer look at the EU's post-Lisbon Treaty jurisdiction over environmental and energy matters.

\subsection{Supra-national Complexity: The Law Making Power of the EU}

The EU treaties form the primary source of EU law. EU legislation adopted under the authority of the treaties forms the secondary source. ${ }^{187}$ All legislation must be based on a provision of the treaties and is subordinate to the treaties. The legislative process starts with the Commission, the institution responsible for drafting and proposing legislation. ${ }^{188}$ The legislative proposal is then submitted to the Council and the

\footnotetext{
184 See David Edward \& Robert Lane, Edward and Lane on European Union Law (Cheltenham, UK: Edward Elgar, 2013) at 28-29 for a summary of the history of the EU.

${ }^{185}$ Foster, supra note 176 at 15.

${ }^{186}$ TEU, supra note 177; and Treaty on the Functioning of the European Union, 13 December 2007, [2010] OJ, C 83/47 [TFEU]. A good portion of EU legislation is also applicable to Norway, Iceland and Liechtenstein through the Agreement on the European Economic Area, 2 May 1992, [1994] OJ, L 1/3 [EEA Agreement]. See Edward \& Lane, supra note 184 at 903-904.

${ }^{187}$ Foster, supra note 176 at 104-107.

188 Article 17(2) \& (4) of the TFEU, supra note 186. The Council and the Parliament can request the Commission to prepare studies and proposals: Articles 225 and 241 of the TFEU.
} 
Parliament for the first reading. ${ }^{189}$ The Parliament, the only institution directly elected by the EU citizens, approves, rejects or amends the proposal. ${ }^{190}$ The proposal and the Parliament's position are subsequently submitted to the Council, which is composed of one ministerial representative from each member state. ${ }^{191}$ A qualified majority (55\% of Council members, representing at least $65 \%$ of the EU population) is needed for the adoption of most legislative acts by the Council under the ordinary legislative procedure. ${ }^{192}$ If the Parliament and the Council have the same position, the proposal is adopted. If there is disagreement, the proposal is submitted for a second and possibly a third reading. ${ }^{193}$

Legislative acts take three forms: regulations, directives, and decisions. ${ }^{194}$ These forms are not hierarchical; their difference lies in their scope and effect. ${ }^{195}$ Regulations are binding legislative acts of general application and directly applicable in all member states; they are considered part of the domestic legal order. ${ }^{196}$ Directives bind member states and are designed to harmonise national legislation or policies. ${ }^{197}$ Concerned member states are responsible for implementing the directive and thus possess more leeway to determine how they will fulfil their obligations, which often take the form of

\footnotetext{
${ }^{189}$ Article 294 of the TFEU, ibid; Kaczorowska, supra note 177 at 154-158; Foster, supra note 176 at 75; Edward \& Lane, supra note 184 at 131-134; and Robert Schütze, An Introduction to European Law (Cambridge: Cambridge University Press, 2012) at 34-40. The proposal is also submitted for advice to the national parliaments, and, as provided by the treaties, to the Economic and Social Committee and the Committee of the Regions.

${ }^{190}$ Article 14 of the TEU, supra note 177; and Edward \& Lane, ibid at 123-124.

${ }^{191}$ Article 16(2) of the TEU, ibid.

${ }^{192}$ Article 16(4), ibid; Edward \& Lane, supra note 184 at 117-120; Kaczorowska, supra note 177 at 76-79; Schütze, supra not e189 at 22-25; and Foster, supra note 176 at 54.

${ }^{193}$ Article 294 of the TFEU, supra note 186; see also Edward \& Lane, ibid at 131-134; Kaczorowska, ibid at 156-158; Schütze, ibid at 37-42; and EC, Joint Declaration of the European Parliament, the Council and the Commission on Practical Arrangements for the Codecision Procedure, [2007] OJ, C 145/5.

${ }^{194}$ Article 288 of the TFEU, ibid.

${ }^{195}$ Edward \& Lane, supra note 184 at 327; and Kaczorowska, supra note 177 at 123.

196 Article 288 para 2 of the TFEU, supra note 186; Koninklijke Scholten Honing v Council and Commission, C-101/76, [1977] ECR 797; Kaczorowska, ibid at 125; Koen Lenaerts, Piet Van Nuffel \& Robert Bray, ed, Constitutional Law of the European Union, $2^{\text {nd }}$ ed (London: Sweet \& Maxwell, 2005) at 764-765 [Lenaerts et al]; and Foster, supra note 176 at 107.

${ }^{197}$ Edward \& Lane, supra note 184 at 343; and Kaczorowska, ibid at 125.
} 
prescribed objectives (obligation de résultat). ${ }^{198}$ A directive can become directly applicable if a member state does not implement it within the prescribed time limit. ${ }^{199}$ Decisions are binding solely on its addressees, which can be member states or any legal or natural person. ${ }^{200}$ Regardless of the form, the vast majority of EU legislative acts are applied by the member states. ${ }^{201}$

A legislative act can delegate the power to supplement or amend certain of its non-essential elements through a delegated act. ${ }^{202}$ The objectives, content, scope and duration of the delegation have to be specified by the legislative act. ${ }^{203}$ The Parliament and the Council can object to the adoption of a delegated act within an established period, and can revoke the delegation at any time. ${ }^{204}$ The Commission also has the power, when uniform conditions for the implementation of a legislative act are necessary, to adopt implementing acts. ${ }^{205}$ However, since the implementation of legislative acts is usually the responsibility of the member states, the Commission is required to consult with national authorities through a process called comitology. ${ }^{206}$ Unlike delegated acts, implementing acts cannot amend or supplement a legislative act. ${ }^{207}$

\footnotetext{
${ }^{198}$ Kaczorowska, ibid at 125-127; Lenaerts et al, supra note 196 at 766-768; Eward \& Lane, ibid at 344346; Foster, supra note 176 at 108; and Commission v Germany, C-131/88, [1991] ECR I-825.

${ }^{199}$ Kaczorowska, ibid at 126-127; Lenaerts et al, ibid at 768-773 \& 779-780; Foster, ibid at 108; Marshall v Southampton and South-West Hampshire Area Health Authority, C-152/84, [1986] ECR 723; and Faccini Dori v Recreb, C-91/92, [1994] ECR I-3325.

${ }^{200}$ Article 288 para 4 of the TFEU, supra note 186; Yusuf and Al Bakaraat International Foundation $v$ Council and Commission, T-306/01, [2005] ECR II-3533; and Kaczorowska, ibid at 127.

${ }^{201}$ Edward \& Lane, supra note 184 at 312.

${ }^{202}$ Article 290 of the TFEU, supra note 186.

${ }^{203}$ Article 290(1), ibid.

204 Article 290(2), ibid; and EU, Council, Common Understanding on Delegated Acts, Doc 8753/11, Brussels, 10 April 2010.

${ }^{205}$ Article 291 of the TFEU, ibid. Implementing acts can also arise under a delegated act: Kaczorowska, supra note 177 at 131.

${ }^{206}$ Article 291(3) of the TFEU, ibid; EU, Regulation 182/2011 of the European Parliament and of the Council of 16 February 2011 laying down the rules and general principles concerning mechanisms for control by Member States of the Commission's exercise of implementing powers, [2011] OJ, L 55/13
} 
Finally, EU legislative acts are subject to the principle of supremacy, also known as primacy, "a cornerstone principle of Community law."208 The principle was first formulated by the ECJ in Costa. ${ }^{209}$ Put simply, the principle means that EU law has precedence over domestic law. National authorities are required to amend or repeal legislation and other measures conflicting with EU law, while national courts have to interpret national legislation in conformity with EU law as far as possible, and when impossible, to declare it invalid. ${ }^{210}$

\subsection{A Question of Competence: The EU Environmental and Energy Jurisdiction}

The EU is a political body of conferred jurisdiction. EU legislation can only be adopted in fields where the EU has exclusive or shared competence according to the treaties (principle of conferral). ${ }^{211}$ As the original treaties did not deal with environmental protection, the first EU actions in the field were declaratory rather than binding. After the first Environmental Action Programme of 1973, the EU started using its policy

[Implementing Powers Regulation]; Edward \& Lane, at 108-110; and Kaczorowska, ibid at 131-132. See also EC, Council Decision 1999/468 of 28 June 1999 laying down the procedures for the exercise of implementing powers conferred on the Commission, [1999] OJ, L 184/23 as amended by EC, Council Decision 2006/512 of 17 July 2006, [2006] OJ, L 200/11.

207 Article 291(2) of the TFEU, supra note 186; and Kaczorowska, ibid at 131.

${ }^{208}$ EU, Declaration concerning primacy, 13 December 2007, [2010] OJ, C 83/344.

${ }^{209}$ Costa v ENEL, C-6/64, [1964] ECR 585.

${ }^{210}$ Lenaerts et al, supra note 196 at 667-670; Kaczorowska, supra note 177 at 247-249; The Queen v Secretary of State for Transport, ex parte Factortame, C-213/89, [1990] ECR I-2433; Fratelli Costanzo v Comune di Milano, C-103/88, [1989] ECR 1861; Commission v Italy, C-159/78, [1979] ECR 3247; Amministrazione delle finanze dello Stato v Simmenthal, C-106/77, [1978] ECR 629; Ministero delle Finanze v IN.CO.GE.'90, C-10/97 to C-22/97, [1998] ECR I-6307; Freskot AE v Elliniko Dimosio, C355/00, [2003] ECR I-5263; and Sociedad Cooperativa General Agropecuaria (ACOR) v Administración General del Estado, C-416/01, [2003] I-14083. The supremacy of EU law is even applicable to constitutional law: Internationale Handelsgesellschaft mbH v Einfuhr- und Vorratsstelle für Getreide und Futtermittel, C-11/70, [1970] ECR 1125; and Foster, supra note 176 at 143-145.

${ }^{211}$ Article 5(2) of the TEU. See also Commission v Council, C-370/07, [2009] ECR I-8917; and Davies, supra note 179 at 3. 
harmonisation and residual powers to adopt binding environmental legislative acts. ${ }^{212}$ There is now no doubt that the EU possesses broad powers to deal with environmental issues. This subsection surveys the EU's current competences in environmental and energy matters - recognized for the first time as shared competences by the Lisbon Treaty - upon which the EU actions in the field of renewable energy are founded. ${ }^{213}$

\subsubsection{Established Competences: Protecting and Improving the Environment}

One of the goals of the EU is to ensure a high level of protection and the improvement of the environment. ${ }^{214} \mathrm{EU}$ actions to reach this goal are based mainly on Articles 191 and 192 of the TFEU. ${ }^{215}$ Article 191(2) and (3) provide that EU environmental policy must be based on the precautionary, polluter pays, prevention and high level of protection principles, and must take into account scientific data, environmental conditions and socio-economic factors. The objectives of EU environmental policy - "preserving, protecting and improving the quality of the environment; protecting human health; prudent and rational utilisation of natural resources; and promoting measures at international level to deal with regional or worldwide environmental problems and in particular combating climate change" - are broad and largely undefined, which gives the EU the flexibility it needs to adapt its actions to new developments. ${ }^{216}$ Additionally, member states are allowed to adopt more

\footnotetext{
${ }^{212}$ Florence Simonetti, “Le droit européen de l'environnement” (2008) 127 Pouvoirs 67 at 68; and von Homeyer, supra note 178.

${ }^{213}$ Article 4(2)(e) \& (i) of the TEU, supra note 177; and Hans Vedder, "The Treaty of Lisbon and European Environmental Law and Policy" (2010) 22:2 J Env L 285. The Lisbon Treaty is the first treaty of the EU that explicitly enumerates exclusive and shared competences.

214 Article 3(3) of the TEU, ibid.

215 Articles 191 \& 192 of the TFEU, supra note 186, were formerly Articles 174 and 175 of the Treaty establishing the European Community, 31 August 1992, [1992] OJ, C 224/1 [TEC].

${ }_{216}$ Article 191(1) of the TFEU, ibid. See also Jan H Jans and Hans H B Vedder, European Environmental Law, $3^{\text {rd }}$ ed (Gorningen: Europa Law Publishing, 2008) at 26-28 \& 30-33; Davies, supra note 179 at 37 ;
} 
stringent measures than those adopted under Article $192 .{ }^{217}$ The treaty basis for the adoption of environmental measures, Article 192(1) of the TFEU, provides for the use of the ordinary legislative procedure in consultation with the Economic and Social Committee and the Committee of the Regions. Article 192(2), however, mandates that in some cases Council unanimity is required. One of those cases is "measures significantly affecting a Member State's choice between different energy sources and the general structure of its energy supply". ${ }^{218}$ However the threshold for establishing a significant effect is quite high and in fact the Renewable Energy Directive was not deemed to be part of that exception. ${ }^{219}$

The provision on the harmonisation of national legislation affecting the establishment or functioning of the common market is also an important legal basis for EU environmental legislation. ${ }^{220}$ This provision is often engaged when the EU is attempting to adopt measures affecting commerce, such as restrictions on the movement of hazardous waste, or environmental standards such as fuel quality. ${ }^{221}$ The mere fact that an environmental measure could affect the internal market is not sufficient to mandate the use of Article 114 as a treaty basis, rather the functioning of the internal market must be

David Benson \& Andrew Jordan, “A Grand Bargain or an 'Incomplete Contract'? EU Environmental Policy after the Lisbon Treaty" (2008) 17 Eur Energy \& Env L Rev 280 at 284; Javier de Cendra de Larragan, "EU climate and energy law: challenges for member states", in Marjan Peeters, Mark Stallworthy \& Javier de Cendra de Larragan, eds, Climate Law in EU Member States: Towards National Legislation for Climate Protection (Cheltenham, UK: Edward Elgar, 2012) at 40-41; Maria Lee, "The Environmental Implications of the Lisbon Treaty" (2008) 10 Env L Rev 131 at 133; and Carlame, supra note 179 at 157158. The Article applies even to measures that do not directly improve or protect the environment such as access to environmental information.

${ }^{217}$ Article 193 of the TFEU, supra note 186.

${ }^{218}$ Article 192(2)(c), ibid.

219 Jans \& Vedder, supra note 216 at 56-57; and Davies, supra note 179 at 18 . The Directive was not challenged on that point.

${ }^{220}$ Article 114 of the TFEU, supra note 186. This article was formerly Article 95 of the TEC, supra note 215.

${ }^{221}$ Jans \& Vedder, supra note 216 at 66-68; and Commission v Italy, supra note 179. 
the provision's primary goal (such as when the difference in national provisions creates trade barriers). ${ }^{222}$ When Article 114 is the treaty basis for a provision, member states cannot adopt more stringent measures then those found in the provision. ${ }^{223}$

Article 207 of the TFEU on the Common Commercial Policy, an EU exclusive competence, can also serve as legal basis when an environmental measure deals with international trade in a non-incidental manner, such as endangered species trade. ${ }^{224}$ Finally, considering the integration principle found in Article 11 of the TFEU, the EU can also use the provisions of the Common Agricultural Policy (hereafter the CAP), the Common Transport Policy, indirect taxes harmonisation, research and development, and nuclear energy and safety as a legal basis for environmental measures when appropriate. $^{225}$

\footnotetext{
${ }^{222}$ Commission v Council, C-155/91, [1993] ECR I-963; Parliament v Council, C-187/93, [1994] ECR I2857; and Jans \& Vedder, ibid at 68.

${ }^{223}$ de Cendra de Larragan, supra note 216 at 42. There are some exceptions: Article 114(4)(5) \& (6) of the TFEU, supra note 186.

${ }^{224}$ Jans \& Vedder, supra note 216 at 70-76; and Commission v Parliament and Council, C-178/03, [2006] ECR I-129. See also Commission v Italy, C-173/05, [2007] ECR I-4917. Interestingly, environmental protection can also serve as an exception on the prohibition of trade restriction found in Article 36 of the TFEU, supra note 186: Commission v Denmark, C-302/86, [1988] ECR 4607; PreussenElektra v Schhleswag, C-379/98, [2001] ECR I-2099; Volker Oschmann, "Renewable Energy Sources in European Law: an Overview" (2006) 3 J Eur Env \& Plan L 478 at 480-481; and Simonetti, supra note 212 at 69.

${ }^{225}$ Articles 38-44, 90-100, 110-113 \& 179-190 of the TFEU, ibid; Chapter 3 of Title II of the Treaty establishing the European Atomic Energy Community, [2010] OJ, C 84/1; United Kingdom v Council, C68/86, [1988] ECR 855; Mondiet v Armement Islais, C-405/92, [1993] ECR I-6133; EC, Communication from the Commission on Tax policy in the European Union - priorities for the years ahead, $\operatorname{COM}(2001)$ 260, [2001] OJ, C 284/6; Parliament v Council, C-70/88, [1991] ECR I-4529; EC, Decision 1513/2002 of the European Parliament and of the Council of 27 June 2002 concerning the sixth framework programme of the European Community for research, technological development and demonstration activities, contributing to the creation of the European Research Area and to innovation, [2002] OJ, L 232/1; and Jans \& Vedder, ibid at 77-84. Nota bene: national discriminatory taxes cannot be saved by environmental justification contrary to Article 30 of the TEC, supra note 215: Commission v Greece, C-375/95, [1997] ECR I-5981.
} 


\subsubsection{Contested Territory: Jurisdiction over Energy}

Energy is also a shared competence subject to the ordinary legislative

procedure. $^{226}$ EU energy policy aims to

(a) ensure the functioning of the energy market;

(b) ensure security of energy supply in the Union;

(c) promote energy efficiency and energy saving and the development of new and renewable forms of energy; and

(d) promote the interconnection of energy networks. ${ }^{227}$

Two broad principles found in the chapeau of Article 194(1) of the TFEU govern the adoption of energy measures: the context of the internal market, and the need to preserve and improve the environment. This emphasis on environmental protection and efficient and/or renewable energy clearly underlines the importance of environmental considerations in energy policy. ${ }^{228}$ Additionally, the structure of the treaties and the behaviour of the EU institutions indicate that this competence of the EU extends to external relations. $^{229}$

Even though member states have shown reluctance in giving away their control over energy sources, the Commission has already had considerable influence on member

\footnotetext{
${ }^{226}$ Angus Johnston \& Eva van der Marel, "Ad Lucem? Interpreting the New EU Energy Provision, and in Particular the Meaning of Article 194(2)TFEU” (2013) 22 Eur Energy \& Env L Rev 181 at 181; and Vedder, supra note 213 at 291.

${ }^{227}$ Articles 194(1) \& 194(2), para 1, of the TFEU, supra note 186. Article 194(2), para 2, \& (3) establish similar limits on the ordinary legislative procedure as Article 192(2)(a) \& (c). See also Article 170 on the establishment of trans-European networks for energy infrastructures.

${ }^{228}$ Vedder, supra note 213 at 291.

229 Leigh Hancher \& Francesco Maria Salerno, "Energy Policy after Lisbon”, in Andrea Biondi, Piet Eeckhout \& Stefanie Ripley, eds, EU Law after Lisbon (Oxford: Oxford University Press, 2012) at 394; Calliess \& Hey, supra note 175 at 11; and Bart van Vooren, "EU external energy policy: the legal and policy impact of the new competence", in Martin Trybus \& Luca Rubini, eds, The Treaty of Lisbon and the Future of European Law and Policy (Cheltenham, UK: Edward Elgar, 2012).
} 
states' national energy choices (through harmonization and environmental measures). ${ }^{230}$

The codification of the EU energy competence in 2009 through the Lisbon Treaty will surely only increase the supranational organisation's influence in that sector. ${ }^{231}$ In fact, the Commission has already proposed some legislation that could arguably not have been adopted under the Treaty establishing the European Community. ${ }^{232}$ The exact scope of Article 194(1) will depend on the interpretation of the limitation imposed by Article 194(2), mainly by the ECJ, which has yet to adjudicate any dispute involving the article. ${ }^{233}$ For now, the Commission has continued to rely predominantly on Articles 192 and 114 of the TFEU to adopt its renewable energy measures while leaving Article 194 aside even though such measures would fit under $(1)(c) .{ }^{234}$

\section{A Second Chance for Biofuels: The 2009 Renewable Energy Directive}

The adoption of the 2009 Renewable Energy Directive did not happen in a vacuum as the EU's interest in renewable energy is not new. The supranational organisation started adopting policy on renewables in the early 1990s, relying on its

\footnotetext{
${ }^{230}$ Gwenaele Rashbrooke, "Clarification or Complication - The New Energy Title in the Draft Constitution for Europe" (2004) 22 J Energy \& Nat'l Res L 373 at 375. An excellent example is the object of this thesis, the Renewable Energy Directive.

${ }^{231}$ Hancher \& Salemo, supra note 229 at 375-376 \& 382; Kirstyn Inglis, "Anticipating New Union Competences in Energy" (2008) 15 Maastricht J Eur \& Comp L 125 at 129-134; and EC, Commission, Green Paper: Towards a Secure, Sustainable and Competitive European Energy Network, 13 November $2008, \operatorname{COM}(2008) 782$. Calliess \& Hey, supra note 175 at 11 , qualify the new energy jurisdiction as a considerable political victory for the EU.

${ }^{232}$ Hancher \& Salemo, ibid at 384.

${ }^{233}$ Johnston \& van der Marel, supra note 226; and Calliess \& Hey, supra note175 at 7-8. Calliess \& Hey, at 6-7, argue that the "EU's newfound authority over energy policy solely empowers it to promote the technological development of renewable energies, whereby any economically or ecologically motivated support henceforth is governed by environmental regulations."

${ }^{234}$ EU, Directive 2015/1513 of the European Parliament and of the Council of 9 September 2015 amending Directive 98/70/EC relating to the quality of petrol and diesel fuels and amending Directive 2009/28/EC on the promotion of the use of energy from renewable sources, [2015] OJ, L 239/1 [ILUC Directive] uses the same legal basis as the Renewable Energy Directive, i.e. Articles 114 and 192 of the TFEU, supra note 186.
} 
harmonization and new environmental competences, in order to reduce GHG emissions. ${ }^{235}$ The EU saw from an early stage that the promotion of renewables was a crucial element of climate change mitigation. The 2009 Renewable Energy Directive can thus be seen as the culmination of many years of progressive promotion of renewables. ${ }^{236}$ The Directive is however the first legislative act with mandatory targets involving a significant role for biofuels. Therefore its impacts will arguably be much more important than previous EU policy on the subject. This section is primarily dedicated to the analysis of the Renewable Energy Directive, the centerpiece of this thesis. It begins with a brief history of steps leading to the adoption of the Directive. It then takes a closer look at the provisions of the Directive relevant for biofuels.

\subsection{A Tortuous Road: Legislative Development Leading to the Directive}

The first renewable energy measure adopted by the EU was the Renewable Energy Decision creating the Altener programme in $1993 .{ }^{237}$ It made funding available for the development and promotion of the use of renewable energy by member states from 1993 to $2002 .^{238}$ Some of the funded projects concerned information exchange on biofuels and other bioenergy. ${ }^{239}$ In addition, the EU permitted member states to favour

\footnotetext{
${ }^{235}$ Davies, supra note 179 at 293; and Oschmann, supra note 224 at 482.

${ }^{236}$ Seita Romppanen, "Regulating Better Biofuels for the European Union” (2012) 21 Eur Energy \& Envtl L Rev 123 at 123-124.

${ }^{237}$ EEC, Council Decision 93/500 of 13 September 1993 concerning the promotion of renewable energy sources in the Community, [1993] OJ, L 235/41 [Renewable Energy Decision]; and Davies, supra note 179 at 293.

${ }^{238}$ Article 2 of the Renewable Energy Decision, ibid; and EC, Council Decision 98/352 of 18 May 1998 concerning a multiannual programme for the promotion of renewable energy sources in the Community (Altener II), [1998] OJ, L 159/53; and EC, Decision 646/2000 of the European Parliament and of the Council of 28 February 2000 adopting a multiannual programme for the promotion of renewable energy sources in the Community (Altener) (1998 to 2002), [2000] OJ, L 79/1.

${ }^{239}$ Davies, supra note 179 at 294.
} 
renewable energy over other energy sources. ${ }^{240}$ It was also during that period that the Commission recognized the importance of and the need to promote renewable energy. ${ }^{241}$ Nevertheless, from 1991 to 2001, the EU renewable energy share increased only from 4 to $6 \%$, a small increase due more to the accession to the EU of Austria, Finland and Sweden than the programme. ${ }^{242}$ For the next phase (2000 to 2010) the Commission wished to achieve a $12 \%$ share of renewable energy. ${ }^{243}$ The EU thus adopted a target of $22 \%$ for electricity produced from renewables through the 2001 Renewable Energy Directive. $^{244}$ This Directive also allowed favoring renewables over other energy sources. ${ }^{245}$ The Directive included bioenergy as a renewable source, but it provided no other criteria for bioenergy except for a general definition of biomass at Article 2(b).

To complement the 2001 Directive, the EU adopted the 2003 Renewable Energy Directive dealing specifically with biofuels. ${ }^{246}$ It created a target of $5.75 \%$ for renewable energy in the transportation sector - expected to be met mainly through the use of biofuels - for 18 May 2010..$^{247}$ The 2003 Renewable Energy Directive was a step in

\footnotetext{
${ }^{240}$ Article 8(3) of EC, Directive 96/92 of the European Parliament and of the Council of 19 December 1996 concerning common rules for the internal market in electricity, [1996] OJ, L 27/20; and Davies, ibid at 295. See also Bram Delvaux, "Promoting Biofuels in Energy Supply: the European Legal Framework" (2004) 13 Eur Env L Rev 66 at 70-71 on state subsidies.

${ }^{241} \mathrm{EC}$, Communication from the Commission on Energy for the future: Renewable Sources of Energy, White paper for a community strategy and action plan, 26 November 1997, COM(97) 599.

${ }^{242}$ Davies, supra note 179 at 294.

${ }^{243}$ EC, Commission, Green paper: Towards a European strategy for the security of energy supply, 29 November 2000, COM(2000) 769 [2000 Green Paper]; and EC, Commission, White paper: European transport policy for 2010: time to decide, 12 September 2001, COM(2001) 370, at 87.

${ }^{244}$ EC, Directive 2001/77 of the European Parliament and of the Council of 27 September 2001 on the promotion of electricity produced from renewable energy sources in the internal electricity market, [2001] OJ, L 283/33 [2001 Renewable Energy Directive]. The adoption of the Directive was also prompted by the need to harmonize the various national schemes for the promotion of electricity produced from renewable energy sources: Davies, supra note 179 at 296.

${ }^{245}$ Article 4(1) of the 2001 Renewable Energy Directive, ibid; and Oschmann, supra note 224 at 481.

${ }^{246}$ EC, Directive 2003/30 of the European Parliament and of the Council of 8 May 2003 on the promotion of the use of biofuels or other renewable fuels for transport, [2003] OJ, L 123/42 [2003 Renewable Energy Directive].

${ }^{247}$ Article 3(1)(b)(ii) of the 2003 Renewable Energy Directive, ibid; and Delvaux, supra note 240 at 72.
} 
achieving the ambitious goal of $20 \%$ renewable fuel consumption in the road transport sector by $2020 .^{248}$ The Directive also asked member states to promote bioenergy and familiarize the public with biofuels and their availability in the EU. ${ }^{249}$ Measures had to take into consideration climate and environmental impacts of biofuels and could favour "fuels showing a very good cost-effective environmental balance, while also taking into account competitiveness and security of supply." ${ }^{, 250}$ The 2003 Directive divided biofuels in three "permissible" categories: pure biofuels or biofuels at high concentration in gasoline or diesel; biofuel and fossil fuel blends; and liquid derived from biofuels. ${ }^{251}$ Both the targets for renewable energy set out by the 2001 and 2003 Directives were not expected to be met by $2010 .{ }^{252}$ Part of the failure is attributed to the absence of mandatory targets and the lack of efficient Commission enforcement power in both Directives. ${ }^{253}$

\subsection{Renewable Energy and Biofuels: The Purpose and Provisions of the Directive}

The Commission responded to the partial failure of the 2001 and 2003 Directives by replacing them with the 2009 Renewable Energy Directive. The 2009 Directive is the legal outcome of the 2006 Renewable Energy Road Map, and the answer to the call for

\footnotetext{
2482000 Green Paper, supra note 243; and Preamble at Recital 17 of the 2003 Renewable Energy Directive, ibid.

${ }^{249}$ Articles 1, 3(1) \& (5), \& 4(1) of the 2003 Renewable Energy Directive, ibid; and Anna Jung et al, Biofuels - At What Cost? Government Support for Ethanol and Biodiesel in the European Union - 2010 Update (Geneva: International Institute for Sustainable Development, 2010) at 25.

${ }^{250}$ Article 3(4) of the 2003 Renewable Energy Directive, ibid.

${ }^{251}$ Article 3(2), ibid.

${ }^{252}$ EC, Communication from the Commission on the Renewable Energy Progress Report, 24 April 2009, $\operatorname{COM}(2009) 192$ [2009 Progress Report]; and Jung et al, supra note 249 at 24. The share of renewable energy in the transport sector was estimated at $4.2 \%$ for 2010.

${ }^{253} 2009$ Progress Report, ibid; Jung et al, ibid at 24; and Iñigo Del Guayo, "Biofuels: EU Law and Policy", in Don Zillman et al, eds, Beyond The Carbon Economy: Energy Law in Transition (Oxford: Oxford University Press, 2008) at $273 \& 275$. Delvaux, supra note 240 at 73, partially foresaw this weakness.
} 
binding targets from the Parliament and the Council. ${ }^{254}$ The Proposal for the 2009 Renewable Energy Directive underlines the Commission's belief that renewable energy has great potential to ensure EU energy security while helping with climate change mitigation and economic development. In the words of the Commission:

There was wide support for a stronger policy on renewable energy sources and notably to a longer-term target for renewable energy, with suggestions ranging from $20 \%$ in 2020 to $50 \%$ and more by 2040/2050. The use of obligatory targets was widely supported, as was the internalisation of external costs. $^{255}$

After negotiation between the Commission, the Council and the Parliament, the climate package, of which the Renewable Energy Directive was a part, was adopted in the spring of 2009. In September 2015, as a response to the 2010 Report from the Commission on indirect land-use change related to biofuels and bioliquids (hereafter the ILUC Report), the Directive was amended to deal with the issue of ILUC. ${ }^{256}$ What permeates the procedures leading to the adoption of this legislation and its amendments is that biofuels were a contentious issue. ${ }^{257}$ It is therefore not a surprise that biofuels occupy a central place in the Directive. This subsection seeks to flesh out the content of the Renewable Energy Directive focusing first on its general provisions and subsequently on the sustainability criteria.

\footnotetext{
254 EC, Commission, Proposal for a Directive of the European Parliament and of the Council on the promotion of the use of energy from renewable sources, 23 February 2008, COM(2008) 19 [2008 Proposal] at 2; EC, Communication from the Commission on a Renewable Energy Road Map, Renewable energies in the 21st century: building a more sustainable future, 10 January 2007, COM(2006) 848; and Preamble at Recitals 8-10 \& 13 of the Renewable Energy Directive, supra note 180. The Renewable Energy Directive has not been incorporated into the EEA Agreement yet.

2552008 Proposal, ibid at 5.

${ }^{256}$ ILUC Directive, supra note 234. See also EU, Report from the Commission on indirect land-use change related to biofuels and bioliquids, 22 December 2010, COM(2010) 811 at 3-4 [ILUC Report]; and Bettina Kretschmer, The Land-use Implications of EU Bioenergy Policy - Going Beyond ILUC (London: Institute for European Environmental Policy, 2011) at 3-4.

257 See EC, Debates of the European Parliament, Sitting of Tuesday, 16 December 2008, [2008] OJ; and EU, Parliament, Legislative Observatory, Fuels and energy from renewable sources: transition to biofuels to deliver greenhouse gas savings, Procedure 2012/0288(COD), online: www.europarl.europa.eu < http://www.europarl.europa.eu/oeil/popups/ficheprocedure.do?lang=en\&reference=2012/0288(COD) $>$.
} 


\subsubsection{Purpose and Structure}

The Renewable Energy Directive is based on Article 175(1) of the Treaty establishing the European Community (now Article 192(1) of the TFEU) with the exception of Articles 17 to 19 (the sustainability criteria) which were based on the harmonisation provision. ${ }^{258}$ The main goal of the Directive is to promote the use of renewable energy through the establishment of mandatory targets in general, and in the transport sector in particular. ${ }^{259}$ Article 3(1) of the Renewable Energy Directive sets the target for renewable energy at $20 \%$ of the EU gross final consumption of energy in $2020 .^{260}$ Each member state has a different national target in order to reach the overall target set out in Annex I which takes into account its 2005 share of renewable energy. ${ }^{261}$ For example, Malta's target is $10 \%(0 \%$ in 2005$)$ but Sweden's target is $49 \%(39.8 \%$ in 2005). ${ }^{262}$ Additionally, member states need to "ensure that the share of energy from renewable sources in all forms of transport in 2020 is at least $10 \%$ of the final consumption of energy in transport in that Member State." 263 The assessment of the total consumption of energy in transport is based on the consumption of gasoline, diesel, biofuels and electricity in road and rail transport, and thus excludes air transport. ${ }^{264}$ The share of renewables is calculated in percentage by dividing the gross final renewable

\footnotetext{
${ }^{258}$ Preamble at the Chapeau \& Recital 94 of the Renewable Energy Directive, supra note 180; and Romppanen, supra note 236 at 127.

${ }^{259}$ Preamble at Recital 14 and Article 1 of the Renewable Energy Directive, ibid.

${ }^{260}$ Member states are encouraged to promote energy efficiency and energy saving: Article 3(1), ibid. See also Articles $14 \& 21(1)$.

${ }^{261}$ Article 3(1) and Annex 1, ibid.

${ }^{262}$ Annex 1, ibid; and Jung et al, 29 at 26.

${ }^{263}$ Article 3(4) of the Renewable Energy Directive, ibid.

${ }^{264}$ Article 3(4)(a), ibid.
} 
energy consumption by the gross final consumption of all energy using the methodology set out in the Energy Statistics Regulation. ${ }^{265}$

To achieve these goals, Article 4 of the Renewable Energy Directive provides that member states must submit a national renewable energy action plan to the Commission. ${ }^{266}$ If the Commission is not satisfied with the adequacy of an action plan, it can issue a recommendation. ${ }^{267}$ Member states also have to submit progress reports to the Commission every two years. ${ }^{268}$ The reports must include information relevant to biofuels on the support scheme for the promotion of renewables, the availability of biomass for energy purposes, changes in commodity prices and land use, the proportion of second generation biofuels, the estimated GHG emissions savings, and the impacts of biofuels production on the environment.

The Commission is required to keep an ongoing dialogue with the stakeholders and in doing so must pay particular attention to the impact of biofuels on food prices. ${ }^{269}$ It is also responsible for monitoring the origin of biofuels consumed in the EU. ${ }^{270}$ The Commission has to produce a report of its own every two years based on its monitoring duty and member states' progress reports which looks at, amongst other things, the environmental benefits and costs of different biofuels, the impact of biofuels on sustainability in the EU and third countries, the impact of biofuels on biomass, the

\footnotetext{
${ }^{265}$ Article 5(6) \& (7), ibid; and EC, Regulation 1099/2008 of the European Parliament and of the Council of October 2008 on energy statistics, [2008] OJ, L 304/1.

${ }^{266}$ Annex VI of the Renewable Energy Directive, ibid; and EC, Commission Decision 2009/548 of 30 June 2009 establishing a template for National Renewable Energy Action Plans under Directive 2009/28/EC of the European Parliament and of the Council, [2009] OJ, L 182/33. The national renewable energy action plans are available at EU, Commission, Directorate-General for Energy, Renewable energy, Action Plans \& Forecasts, online: www.ec.europa.eu < http://ec.europa.eu/energy/renewables/action_plan_en.htm >

${ }^{267}$ Article 4(5) of the Renewable Energy Directive, ibid. No recommendation has been issued.

${ }^{268}$ Article 22, ibid; and Article 2(9) of the ILUC Directive, supra note 234.

${ }^{269}$ Article 23(2) of the Renewable Energy Directive, ibid.

${ }^{270}$ Article 23(1), ibid.
} 
availability of second generation biofuels, and ILUC. ${ }^{271}$ The Commission also has to report on the evaluation of the implementation of the Directive, with specific attention to GHG emissions savings thresholds of Article 17(2), the cost efficiency of measures adopted to achieve the target, the feasibility of the target whilst ensuring the sustainability of biofuels production, and the impact of the Directive on the availability of foodstuffs at affordable prices. ${ }^{272}$ Finally, the Commission has to present in 2018 a Renewable Energy Roadmap for the post-2020 period with appropriate legislative proposals, and in 2021 a report reviewing the application of the Directive. ${ }^{273}$

\subsubsection{Sustainability Criteria}

The $10 \%$ share of total renewable energy consumption in transport is expected to be met mainly through the promotion and use of biofuels. ${ }^{274}$ Conscious of the potential environmental impacts of biofuels production, the Commission, responding to the scepticism of certain member states such as the Netherlands, included sustainability criteria in the Renewable Energy Directive to ensure the sustainable development of biofuels. $^{275}$ The criteria were modified in response to the ILUC Report, which concluded that ILUC has serious impacts on biofuels sustainability, and that the sustainability

\footnotetext{
${ }^{271}$ Article 23(3) \& (5)(a)(b)(c)\&(d), ibid; and Article 2(10)(c) of the ILUC Directive, supra note 234.

${ }^{272}$ Article 23(8)(a)\&(c) of the Renewable Energy Directive, ibid; and Article 2(10)(d) of the ILUC Directive, ibid.

${ }^{273}$ Article 23(9) \& (10) of the Renewable Energy Directive, ibid.

${ }^{274}$ Jung et al, supra note 249 at 26. See also documents list at EU, European Parliament, Legislative Observatory, Promotion of the use of energy from renewable sources: "Renewable Energy Directive", 2008/0016(COD), online: www.europarl.europa.eu < http://www.europarl.europa.eu/oeil/popups/ficheprocedure.do?lang=en\&reference=2008/0016(COD)\#tab-0 >. It is estimated that biofuels will account for between 9.3 and $9.5 \%$ of energy consumption in the transportation sector in 2020: EU, Commission, Executive Summary of the Impact Assessment accompanying the document Communication to the Commission on communicating outcome of the Impact Assessment related to requirements of Article 3(4) of Directive 2009/28/EC, 14 September 2012, $\operatorname{SWD}(2012) 262$ at 2.

${ }^{275}$ Preamble at Recitals 65-85 and Article 17 of the Renewable Energy Directive, supra note 180; and Jung et al, ibid at 28 .
} 
modelling of the Directive was deficient regarding ILUC. ${ }^{276}$ The criteria listed in Article 17(2) to (6) of the Directive must be respected in order for biofuels, irrespective of whether the feedstocks were harvested inside or outside the EU, to count towards either of the renewable energy targets. ${ }^{277}$ There is one exception for biofuels made from "waste and residues, other than agricultural, aquaculture, fisheries and forestry residues", which only need to comply with Article $17(2)$ (the GHG emissions savings provision). ${ }^{278}$ The criteria are also used to establish eligibility for financial support. ${ }^{279}$

Since the 2015 amendments, first generation biofuels are limited to a maximum share of $7 \%$ of the final energy consumption in transport in $2020 .{ }^{280}$ Feedstocks listed in Annex IX, and feedstocks that meet the sustainability criteria and that are grown on certain land (see Annex V, Part C, Points $7 \&$ 8) do not count towards the $7 \%$ cap. The amendments also requires that the consumption of advanced biofuels be at least of $0.5 \%$ of the final energy consumption in transport by 2020, unless a member state can show that (1) there are objective factors limiting the sustainable production of second generation biofuels; (2) there are limits based on the specific technical or climatic characteristics of the national market for transport fuels; and/or (3) there are national policies allocating commensurate financial resources to incentivising energy efficiency

\footnotetext{
${ }^{276}$ ILUC Report, supra note 256 at 14. In fact, the Commission estimates that almost the entire production of biofuels in 2020 will come from feedstocks grown on arable land: Preamble at Recital 5 of the ILUC Directive, supra note 234.

${ }^{277}$ Articles 5(1) at para $3 \& 17(1)$ (a) \& (b) of the Renewable Energy Directive, supra note 180.

${ }^{278}$ Article 17(1) at para 2, ibid.

${ }^{279}$ Article 17(1)(c), ibid. The Directive does not prohibit the introduction of biofuels that do not respect the sustainability criteria into the EU market: Seita Romppanen, "The EU's Biofuels: Certified as Sustainable?" (2012) 3:3 Renewable Energy L \& Pol'y Rev 173 at 176 [S Romppanen].

${ }^{280}$ Article 2(2)(b)(iv) of the ILUC Directive, supra note 234. The Directive uses the following language to describe first generation biofuels: "biofuels produced from cereal and other starch-rich crops, sugars and oil crops and from crops grown as main crops primarily for energy purposes on agricultural land".
} 
and the use of electricity from renewable energy sources in transport. ${ }^{281}$ Eligible advance biofuels are listed in Part A of Annex IX, which can be amended by the Commission through delegated acts. ${ }^{282}$

Additionally, the Commission is in charge of reporting every two years to the Parliament and the Council on measures taken to respect the sustainability criteria by member states, and third countries that are significant EU sources of biofuels or feedstocks. ${ }^{283}$ The Commission will also have to report on the availability of non-land using feedstocks and non-food crops and the targets introduced by the 2015 amendments. $^{284}$

\subsubsection{Five Criteria and a Half}

The first criterion found in Article 17 concerns GHG emissions savings. GHG emissions savings from the use of biofuels have to be at least $60 \%$ if the biofuel was produced in an installation that started operation after 5 October $2015 .^{285}$ Biofuels produced in installations that commenced operation before that date must have GHG emissions savings of at least 35\%. On 1 January 2018, that GHG emissions savings target rises to $50 \%$. The methodology used to establish the GHG emissions savings of biofuels

\footnotetext{
${ }^{281}$ Article 2(2)(b)(iv) of the ILUC Directive, ibid; and EU, Statement of the Council's Reasons on the Position of the Council at first reading with a view to the adoption of a Directive of the European Parliament and of the Council amending Directive 98/70/EC relating to the quality of petrol and diesel fuels and amending Directive 2009/28/EC on the promotion of the use of energy from renewable sources, Brussels, 10 December 2014, ST 10710/2/14 REV 2 ADD 1, at 8. Member states must provide national targets for advance biofuels and set policies to meet them. This information is made public by the Commission.

${ }^{282}$ The Commission must exercise its delegated power in accordance with the new Article 25a which was added by Article 2(12) of the ILUC Directive, ibid.

${ }_{283}^{283}$ Article 17(7) para 1 of the Renewable Energy Directive, supra note 180.

${ }^{284}$ Article 3 of the ILUC Directive, supra note 234.

${ }^{285}$ Article 2(5)(a), ibid.
} 
is found in Annex V of the Renewable Energy Directive. ${ }^{286}$ The Commission remains responsible for keeping the methodology and the data found in the Annex up to date. ${ }^{287}$

The second criterion states that biofuels cannot be made from raw materials that come from land designated as having high biodiversity. ${ }^{288}$ Land is considered designated if it had one of the named statuses in January 2008 or after, whether or not the land continues to have the status in the present. These statuses include: (1) primary forests and other wooded lands with no clearly visible indication of human activities; (2) areas protected by national or international law, or designated as protected areas by national authorities, international organisations or the International Union for the Conservation of Nature (the IUCN); and (3) highly biodiverse grasslands that are either naturally grassland without human intervention, or grasslands that need human intervention for preservation, are not degraded and contain a high number of species. ${ }^{289}$

In a similar fashion as the second criterion, the third criterion excludes from the renewable energy targets biofuels made from feedstocks originating from land with high carbon stock. ${ }^{290}$ These lands must have had the following statuses in January 2008 and subsequently lost it: wetlands, continuously forested areas, and "land spanning more than one hectare with trees higher than five metres and a canopy cover of between $10 \%$ and $30 \%$, or trees able to reach those thresholds". ${ }^{291}$ If the land had the same status in

\footnotetext{
${ }^{286}$ Articles 17(2) at para 3 of the Renewable Energy Directive, supra note 180.

${ }^{287}$ Article 19(4) (5) (7) \& (8), ibid; and Article 2(7)(a)(c) \& (d) of the ILUC Directive, supra note 234. See also EU, Commission Decision 2010/335 of 10 June 2010 on guidelines for the calculation of land carbon stocks for the purpose of Annex V to Directive 2009/28/EC, [2010] OJ, L 151/19; and EU, Report from the Commission on the feasibility of drawing up lists of areas in third countries with low greenhouse gas emissions from cultivation, 10 August 2010, COM(2010) 427.

${ }^{288}$ Article 17(3) of the Renewable Energy Directive, ibid; and Jung et al, supra note 249 at 27.

${ }^{289}$ Article 17(3)(a), (b) \& (c) Renewable Energy Directive, ibid.

${ }^{290}$ Article 17(4), ibid.

${ }^{291}$ Article 17(4)(a), (b) \& (c), ibid.
} 
January 2008 as at the time of the feedstocks extraction, the provision does not apply. ${ }^{292}$

The fourth criterion adds that feedstocks cannot be made from raw materials harvested in land that was considered peatland in January $2008 .^{293}$

Finally, the last criterion indicates that agricultural raw materials cultivated in the EU and used for the production of biofuels are required to respect certain provisions of the CAP Council Regulation 73/2009, ${ }^{294}$ namely points 1 to 5 and 9 of Annex II, and Article 6(1). ${ }^{295}$ Points 1 to 5 and 9 of Annex II list a number of Directives covering topics such as biodiversity conservation, groundwater pollution, agricultural pollution, and pesticides. Article 6(1) mandates member states to establish minimum requirements for good agricultural and environmental conditions. ${ }^{296}$ The requirements are divided into compulsory and optional standards. The optional standards become compulsory if the member state has already defined the standard before 1 January 2009, or if a national rule addressing the standard exists. ${ }^{297}$

Notably absent from the sustainability criteria is reference to the social aspect of sustainable development. Nonetheless, social sustainability does make a "soft" appearance in Article 17 in the form of reporting obligations. ${ }^{298}$ Every two years the

\footnotetext{
${ }^{292}$ Article 17(4) para 2, ibid.

${ }^{293}$ Article 17(5), ibid.

294 EC, Council Regulation 73/2009 of 19 January 2009 establishing common rules for direct support schemes for farmers under the common agricultural policy and establishing certain support schemes for farmers, amending Regulations (EC) No 1290/2005, (EC) No 247/2006, (EC) No 378/2007 and repealing Regulation (EC) No 1782/2003, [2009] OJ, L 30/16 [CAP Direct Support Schemes Regulation].

${ }^{295}$ Article 17(6) of the Renewable Energy Directive, supra note 180.

${ }^{296}$ Annex III of the CAP Direct Support Schemes Regulation, supra note 294. Requirements not foreseen by Annex III cannot be defined by a member state.

297 Article 6(1) para 2, ibid. See Rocio Diaz-Chavez et al, Mandatory requirements in relation to air, soil, or water protection: analysis of need and feasibility, Final Report - Tasks 3 \& 4 (Utrecht: ECOFYS, 2013) at 50 for examples of standards set by Spain, Germany and Poland.

${ }^{298}$ Article 17(7) para 2 of the Renewable Energy Directive, supra note 180; and Jody M Endres, "Clearing the Air: The Meta-standard Approach to Ensuring Biofuels Environmental and Social Sustainability" (2010) 28 Va Envtl LJ 73 at 99.
} 
Commission must report to the Parliament and the Council on the impact of the increased demand for biofuels on social sustainability in general, on the availability of foodstuffs at affordable prices - especially in developing countries - and on land-use rights. Additionally, the Commission must list countries, both member states and third countries, which are significant sources of biofuels or feedstock and indicate whether or not they have ratified and implemented the International Labour Organisation (hereafter the ILO) Conventions No. 29, 87, 98, 100, 105, 111, 138 and $182 .{ }^{299}$ The list must also state whether the countries have ratified and implemented the Cartagena Protocol on Biosafety and the Convention on International Trade in Endangered Species of Wild Fauna and Flora. ${ }^{300}$

\subsubsection{Ensuring Compliance}

Although, as indicated above, the Commission is responsible for reporting on various impacts and progress related to the Renewable Energy Directive to the other EU institutions, the Commission does not directly monitor biofuels compliance with the sustainability criteria. The Directive indirectly imposes the obligation on industry via member states that must compel economic operators to prove their compliance with the sustainability criteria by either providing compliance data directly to the member states, by following the term of an agreement between the EU and third countries recognised by

\footnotetext{
${ }^{299}$ The ILO Conventions deal with the following issues: compulsory or forced labour, union rights, equal remuneration for men and women, and child labour. The Conventions can be found at: ILO, Conventions, online: www.ilo.org < http://www.ilo.org/dyn/normlex/en/f?p=NORMLEXPUB:12000:0::NO::: >.

${ }^{300}$ Article 17(7) para 3 of the Renewable Energy Directive, supra note 180. See Cartagena Protocol on Biosafety, 29 January 2000, 2226 UNTS 208; and Convention on International Trade in Endangered Species of Wild Fauna and Flora, 3 March 1973, 993 UNTS 3.
} 
the Commission, or by adopting recognised certification schemes. ${ }^{301}$ The Commission is thus relying considerably on various voluntary certification schemes developed by industry, non-governmental organisations (hereafter NGOs) and international organisations to monitor compliance with all but one sustainability criteria (the metastandard approach). ${ }^{302}$ It is expected that the certification approach will play a major role in ensuring compliance. ${ }^{303}$ For the remaining criterion, certain parts of Council Regulation 73/2009, the Commission and member states can rely on the existing compliance mechanisms for this Regulation and the directives it refers to. ${ }^{304}$

The Commission has the power to determine which certification schemes are reliable for the purposes of the Directive. ${ }^{305}$ The Commission assesses schemes by ensuring that they meet certain benchmarks (mainly the sustainability criteria) and by ensuring the robustness of the checks in place. ${ }^{306}$ Certification schemes can be divided into two categories: schemes specifically built for biofuels, and those developed to

${ }^{301}$ Article 18(1), (3), (4) \& (7) of the Renewable Energy Directive, ibid; Article 2(6)(a)\&(b) of the ILUC Directive, supra note 234; EU, Communication from the Commission on the practical implementation of the EU biofuels and bioliquids sustainability scheme and on counting rules for biofuels, [2010] OJ, C 160/8 at para 2.1 [Communication on Sustainability Criteria Implementation]; and S Romppanen, supra note 279 at 178-179. The Directive allows the mixing of biofuels or raw materials with differing sustainability characteristics if the economic operators indicate the proportion of the different components of the mix and their respective sustainability characteristics: Article 18(1) Renewable Energy Directive. Economic operators have the onus of maintaining an auditable system: Jolene Lin, "The Environmental Regulation of Biofuels: Limits of the Meta-Standard Approach" (2011) 5:1 CCLR 34 at 39 [J Lin].

302 Jolene Lin, "Governing Biofuels: A Principal-Agent Analysis of the European Union Biofuels Certification Regime and the Clean Development Mechanism" (2011) 24 J of Env L 43 at 53 [Lin]; and S Romppanen, ibid at 179.

${ }^{303}$ S Romppanen, ibid at 179.

${ }^{304}$ Communication on Sustainability Criteria Implementation, supra note 301 at para 2.2.

${ }^{305}$ Article 18(4) of the Renewable Energy Directive, supra note 180; Article 2(6)(b)\&(2) of the ILUC Directive, supra note 234; EU, Communication from the Commission on voluntary schemes and default values in the EU biofuels and bioliquids sustainability scheme, [2010] OJ, C 160/1 [Communication on voluntary schemes]. The Commission is required to follow the opinion of the Committee on the Sustainability of Biofuels and Bioliquids according to the procedure set out in the Implementing Powers Regulation, supra note 206: Article 2(6)(d) and (11) of the ILUC Directive. See also S Romppanen, supra note 279 at 180.

${ }^{306}$ Lin, supra note 302 at 54; S Romppanen, ibid at 179; and J Lin, supra note 302 at 38 . A scheme does not have to cover every criterion and can also cover more sustainability issues than the Directive: Communication on voluntary schemes, supra note 305 at para 2. 
measure certain aspects of sustainability. ${ }^{307}$ The Commission, through its approbation power, serves as the primary guarantor of the reliability of the certification schemes. ${ }^{308}$ This external guaranty is also accompanied by an internal one based on the legitimacy or reputation of voluntary certification schemes. NGOs associated with certification schemes place their reputation on the line as an unreliable certification scheme could damage their own legitimacy, while industry members need reliable schemes to ensure that consumers trust their products as doubt could damage sales and drive consumers to a competitor using a more reliable certification scheme. ${ }^{309}$ A dependable and fraudresistant auditing system is therefore crucial to the effectiveness of this approach. ${ }^{310}$

\section{The Bigger Picture: Other EU Norms Affecting Biofuels}

The Renewable Energy Directive attempts to create a relatively comprehensive framework to ensure the sustainability of biofuels. However, it is not the only legislation capable of affecting bioenergy sustainability. The EU has adopted a wide variety of environmental and energy regulations that directly or indirectly impact the production of feedstocks and biofuels within, and in some circumstances outside, the EU. I do not presume to cover all relevant regulations in this section, considering the extent and complexity of EU environmental law and the limits of this thesis. Nevertheless, this section attempts to outline what I consider the most relevant regulations affecting

\footnotetext{
${ }^{307}$ Lin, ibid at 54.

${ }^{308}$ Lin, ibid at 69. S Romppanen, supra note 279 at 182 notes that this "gate-keeping" depends on how stringent the Commission is in its process.

${ }^{309}$ Lin, ibid at 68-69.

${ }^{310}$ S Romppanen, supra note 279 at 181.
} 
biofuels, mainly those addressing major biofuels concerns, grouped into three categories:

taxation and customs duties, climate change and energy, and agricultural pollution.

\subsection{Taxation and Customs Regulations}

Fiscal measures can have a significant impact on the economic availability of energy products and can be used as a tool to nudge consumers in the "right" direction. As a customs union, the EU has adopted a variety of duties applicable to imported biofuels through the Community Customs Code and the Code's Implementing Provisions. ${ }^{311}$ For the purpose of EU customs, biofuels are treated as vegetable oils, alcohol, mineral fuel/oils or chemical products. ${ }^{312}$ Biodiesel or mixes containing less than $70 \%$ of petroleum oils have a $6.5 \%$ rate of duty. ${ }^{313}$ Mixes of less than $30 \%$ of biodiesel are considered as petroleum product and are subject to a duty of $4.7 \% .{ }^{314}$ Undenatured ethanol is subjected to a rate of $€ 19.2$ per hectoliter and denatured ethanol, which is not consumable by humans, is subjected to a rate of $€ 10.2$ per hectoliter. ${ }^{315}$ Duty rates for vegetable oils vary considerably. ${ }^{316}$ In addition, the Commission adopted antidumping and countervailing duties on US and certain Canadian biodiesel (varying from $€ 23.6$ to

${ }^{311}$ EC, Council Regulation 2913/92 of 12 October 1992 establishing the Community Customs Code, [1992] OJ, L 302/1; and EC, Commission Regulation 2454/93 of 2 July 1993 laying down provisions for the implementation of Council Regulation 2913/92 establishing the Community Customs Code, [1993] OJ, L 253/1. The Community Customs Code will be replaced by the Union Customs Code on 1 May 2016: Articles 286 \& 288 of EU, Regulation 952/2013 of the European Parliament and of the Council of 9 October 2013 laying down the Union Customs Code, [2013] OJ, L 269/1. The tariffs themselves are adopted pursuant to Annex I of EC, Council Regulation 2658/87 of 23 July 1987 on the tariff and statistical nomenclature and on the Common Customs Tariff, [1987] OJ, L 256/1, which is updated every year.

${ }^{312}$ Roland M Stein, "Import of Biofuels and the Marketing of Biofuels in the European Union: an Analysis of the Current Law on Customs, Energy Taxes and Biofuel Quotas" (2008) 26 J Energy \& Nat Res L 600 at 601; and Chapters 15, 22, 27 \& 38 of the EU, Commission Implementing Regulation 1101/2014 of 16 October 2014 amending Annex I to Council Regulation 2658/87 on the tariff and statistical nomenclature and on the Common Customs Tariff, [2014] OJ, L 312/1 [Combined Nomenclature].

${ }^{313}$ Subheading 382600 of the Combined Nomenclature, ibid; and Stein, ibid at 602.

${ }^{314}$ Subheading 271012 of the Combined Nomenclature, ibid.

${ }^{315}$ Heading 2207, ibid; and Stein, supra note 312 at 602-603.

${ }^{316}$ See for example subheadings $15111010,15119091,15071010 \& 15079010$ of the Combined Nomenclature, ibid; and Stein, ibid at 603. 
208.2 per tonne for antidumping duty, and $€ 211.2$ to 237 for countervailing duty) and US ethanol (antidumping duty of €62.3 per tonne), and on Argentina and Indonesia's biodiesel (antidumping duty varying from $€ 76.94$ to 245.67 per tonne) to prevent the EU market from regressing. ${ }^{317}$

The general customs tariffs are however reduced or nullified through the Generalised Scheme of Preferences (hereafter the GSP) for developing countries. ${ }^{318}$ The GSP suspends duties for ethanol and biodiesel as part of its special incentive arrangement for sustainable development and good governance. ${ }^{319}$ To benefit from this arrangement, developing countries need to be considered economically vulnerable, and to have ratified without incompatible reservations and complied with conventions on human rights, labour

\footnotetext{
${ }^{317}$ EC, Council Regulation 1 225/2009 of 30 November 2009 on protection against dumped imports from countries not members of the European Community, [2009] OJ, L 343/51; EC, Council Regulation 599/2009 of 7 July 2009 imposing a definitive anti-dumping duty and collecting definitively the provisional duty imposed on imports of biodiesel originating in the United States of America, [2009] OJ, L 179/26; EC, Council Regulation 598/2009 of 7 July 2009 imposing a definitive countervailing duty and collecting definitively the provisional duty imposed on imports of biodiesel originating in the United States of America, [2009] OJ, L 179/1; EU, Council Implementing Regulation 444/2011 of 5 May 2011 extending the definitive anti-dumping duty imposed by Regulation (EC) No 599/2009 on imports of biodiesel originating in the United States of America to imports of biodiesel consigned from Canada, whether declared as originating in Canada or not, and extending the definitive antidumping duty imposed by Regulation (EC) No 599/2009 to imports of biodiesel in a blend containing by weight $20 \%$ or less of biodiesel originating in the United States of America, and terminating the investigation in respect of imports consigned from Singapore, [2011] OJ, L 122/12; EU, Council Implementing Regulation 443/2011 of 5 May 2011 extending the definitive countervailing duty imposed by Regulation (EC) No 598/2009 on imports of biodiesel originating in the United States of America to imports of biodiesel consigned from Canada, whether declared as originating in Canada or not, and extending the definitive countervailing duty imposed by Regulation (EC) No 598/2009 to imports of biodiesel in a blend containing by weight $20 \%$ or less of biodiesel originating in the United States of America, and terminating the investigation in respect of imports consigned from Singapore, [2011] OJ, L 122/1; EU, Council Implementing Regulation 157/2013 of 18 February 2013 imposing a definitive anti-dumping duty on imports of bioethanol originating in the United States of America, [2013] OJ, L 49/10; EU, Council Implementing Regulation 1194/2013 of 19 November 2013 imposing a definitive anti-dumping duty and collecting definitively the provisional duty imposed on imports of biodiesel originating in Argentina and Indonesia, [2013] OJ, L 315/2; and Jung et al, supra note 249 at 13.

${ }^{318}$ Preamble at Recital 3 of EU, Regulation 978/2012 of the European Parliament and of the Council of 25 October 2012 applying a scheme of generalised tariff preferences and repealing Council Regulation 732/2008, [2012] OJ, L 303/1 [GSP Regulation].
}

${ }^{319}$ Article 11 and Annex IX, ibid. 
rights, environmental protection, and good governance listed in Annex VIII. ${ }^{320}$ Finally, countries listed as least-developed countries by the United Nations are exempt from all duties applicable to biofuels. ${ }^{321}$

Biofuels, as energy products, are also subject to energy taxes. The taxation regime is significantly more opaque than the customs one since jurisdiction over the issue is split between EU, national, and even regional or local governments. ${ }^{322}$ The framework for energy taxes at the EU level is found in the Energy Taxation Directive. ${ }^{323}$ The Directive sets the minimum level of taxation for energy products listed in Article 2, which includes biofuels (mixed or pure) unless they are intended for non-energy uses. ${ }^{324}$ Biofuels are taxed at the same rate as the equivalent fossil fuels according to Annex $1 .^{325}$ To compensate for the higher cost of biofuels production and in order promote the use of renewables, the Energy Taxation Directive permits member states to apply tax exemptions for renewable fuels or fuels containing components produced from biomass (fuel mixes). ${ }^{326}$ Exemptions for fuels containing components produced from biomass can only be authorised once after 2012 for a pre-determined amount of time if the exemption

\footnotetext{
${ }^{320}$ Article 9, ibid.

${ }^{321}$ Articles 17 \& 18, ibid.

${ }^{322}$ Stein, supra note 312 at 603; and John Snape \& Jeremy de Souza, Environmental Taxation Law Policy, Contexts and Practice (Burlington, VT: Ashgate Publishing, 2006) at 294-295.

${ }^{323}$ EC, Council Directive 2003/96 of 27 October 2003 restructuring the Community framework for the taxation of energy products and electricity, [2003] OJ, L 283/51 [Energy Taxation Directive].

${ }^{324}$ Articles 1, 2(1)(3) \& 4, ibid; and Stein, supra note 312 at 604. However, certain undenatured bioethanol, even if not fit for human consumption, can be subject to the alcoholic beverage excise duty under EEC, Council Directive 92/83 of 19 October 1992 on the harmonization of the structures of excise duties on alcohol and alcoholic beverages, [1992] OJ, L 316/21, instead of the Energy Taxation Directive: Evroetil AD v Direktor na Agentsia 'Mitnitsi', C-503/10, [2011] I-14209.

${ }^{325}$ Articles 3 \& 7 to 10 and Annex I of Energy Taxation Directive, ibid. See EU, Commission, Excise Duty Tables: Part II - Energy products and Electricity, July 2013, REF 1038 rev1, online: ec.europa.eu < http://ec.europa.eu/taxation_customs/resources/documents/taxation/excise_duties/energy_products/rates/ex cise_duties-part_ii_energy_products_en.pdf > for up to date rates.

${ }^{326}$ Stein, supra note 312 at 605; Jung et al, supra note 249 28; Snape \& de Souza, supra note 322 at 302; and Preamble at Recitals 25 \& 26 and Articles 15(1)(a) \& 16(1) of the Energy Taxation Directive, supra note 323. The tax exemption is not a right: Plantanol GmbH \& Co KG v Hauptzollamt Darmstadt, C201/08, [2009] ECR I-8343.
} 
scheme existed before 31 December $2012 .{ }^{327}$ Otherwise, only renewable fuels can be exempted from energy taxes after 2012. Although many member states have adopted carbon taxes and the idea of such a tax was advocated by the Commission, the EU does not yet have a uniform or standardized carbon taxation system. ${ }^{328}$ The Energy Taxation Directive does, nonetheless, recognize that taxation can be an important environmental policy tool. ${ }^{329}$

\subsection{Climate Change and Energy Regulations}

One of the main concerns about biofuels is its capacity to be a GHG emissions free, or at least a low GHG emissions, alternative to fossil fuels. The dual nature of biofuels, as a solution and a potential contributor to climate change simultaneously, is reflected in the Renewable Energy Directive through its imposition of sustainability criteria for biofuels. The Directive is however but a part of the broader EU climate change regulatory framework (the European Climate Change Programme) and as such the sustainability of biofuels is also affected by the other parts of this framework, including the Fuel Quality Directive, the GHG Emissions Trading System, and the Energy Efficiency Directive explored below. ${ }^{330}$

\footnotetext{
${ }^{327}$ Article 16(5) of the Energy Taxation Directive, ibid.

${ }^{328}$ EC, Communication from the Commission on Environmental Taxes and Charges in the Single Market, 26 March 1997, COM(97) 9; Stefan Speck, "The Design of Carbon and Broad-based Energy Taxes in European Countries" (2008-2009) 10 Vt J Envt L 31; and Snape \& de Souza, supra note 322 at 293.

${ }^{329}$ Preamble at Recitals 6,7 \& 12 of the Energy Taxation Directive, supra note 323. See also Snape \& de Souza, ibid at 301.

330 Carlame, supra note 179 at 163-164. Renewable energy was a central part of the second European Climate Change Programme: at 167-168.
} 


\subsubsection{Climate Change Mitigation}

The Fuel Quality Directive sets technical specifications on health and environmental grounds, and a GHG emissions reduction target for fuels. ${ }^{331}$ Petrol (gasoline) and diesel are subject to environmental standards found in Annexes I and II and to a decarbonisation target of at least $6 \%$ and up to $10 \%$ by $2021 .{ }^{332}$ Cognizant that biofuels would play an important role in decarbonizing petrol and diesel, the EU requires that biofuels used to meet the target be subject to the same sustainability criteria found in the Renewable Energy Directive following the same compliance framework. ${ }^{333}$

The targets adopted through the Fuel Quality Directive and the Renewable Energy Directive were partly enabled by the existence of the EU Emissions Trading System (hereafter the ETS), a GHG emissions cap-and-trade regime that could be considered as the flagship climate policy of the Union. ${ }^{334}$ By putting a price first on $\mathrm{CO}_{2}$ and subsequently on most GHGs, the ETS encourages the use of renewable energy, the promotion of energy efficiency, and the development of new "greener" technology. It laid

\footnotetext{
${ }^{331}$ Article 1 of the EC, Directive 98/70 of the European Parliament and of the Council of 13 October 1998 relating to the quality of petrol and diesel fuels and amending Council Directive 93/12, [1998] OJ, L 350/58, as amended by Directives 2000/71, 2003/17, 2009/30 \& 2011/63, and by Regulation 1882/2003 (consolidated version of 2011) [Fuel Quality Directive].

${ }_{332}^{332}$ Articles 3, 4 \& 7a, ibid.

${ }^{333}$ Articles 7b \& 7c of the Fuel Quality Directive, ibid; and Article 1 of the ILUC Directive, supra note 234.

${ }^{334}$ The ETS was set out through the EC, Directive 2003/87 of the European Parliament and of the Council of 13 October 2003 establishing a scheme for greenhouse gas emission allowance trading within the Community and amending Council Directive 96/61/EC, [2003] OJ, L 275/32, as amended by Directives 2004/101, 2008/101, 2009/29, by Regulation 219/2009 and by the Treaty of Accession of Croatia (consolidated version of 2011) [ETS Directive]; Carlame, supra note 179 at 172; Ricardo Pereira \& Charlotte Jourdain, "International and EU Climate Change Law", in Karen E Makuch \& Ricardo Pereira, eds, Environmental and Energy Law (Chichester, UK: Wiley-Blackwell, 2012) at 163; European Environment Agency, Trends and projections in Europe 2013 - Tracking progress towards Europe's climate and energy targets until 2020 (Luxembourg: Publications Office of the EU, 2013) at 20-21 [EEA report]; and Markus Pohlmann, "The European Union Emissions Trading Scheme", in David Freestone \& Charlotte Streck, eds, Legal Aspects of Carbon Trading: Kyoto, Copenhagen, and beyond (Oxford: Oxford University Press, 2009) at 339-340 \& 343-344.
} 
down the fertile ground for the adoption of legislation on renewables. ${ }^{335}$ The ETS covers approximately $45 \%$ of EU GHG emissions and operates in Iceland, Liechtenstein and Norway in addition to the 28 member states. ${ }^{336}$ Under this system, installations carrying out activities listed in Annex I must obtain a permit authorising GHG emissions issued by the competent national authority. ${ }^{337}$ The Commission is charged with the maintenance of the Union Registry and setting the Union-wide GHG emissions cap. ${ }^{338}$ Under the current phase (which is the third phase), the EU cap determines the total amount of GHG allowances which are then mainly purchased through auctioning by installations covered by ETS permits. ${ }^{339}$ The cap is progressively decreased each year by $1.74 \%$ of the average total quantity of allowances issued annually during the second phase. ${ }^{340}$ At the end of each year, each permit holder must surrender enough allowance to cover its GHG emissions and may keep extra allowance for future use. ${ }^{341}$ Aircraft operators are subject to the ETS Directive, but under different circumstances. ${ }^{342}$ They receive 0.6422 free

${ }^{335}$ Carlame, ibid at 172.

${ }^{336}$ EU, Commission, Directorate-general for Climate Action, The EU Emissions Trading System (EU ETS) - Policy, 11 February 2014, online: ec.europa.eu < http://ec.europa.eu/clima/policies/ets/index_en.htm > [EU ETS Policy]; Pohlmann, supra not 334 at 346.

${ }^{337}$ Article 4 of the ETS Directive, supra note 334; and Pohlmann, ibid at 349-350. See also Article 5 \& 6 for applications' requirements and conditions.

338 Articles 9 \& 19 of the ETS Directive, ibid; EU, Commission Regulation 389/2013 of 2 May 2013 establishing a Union Registry pursuant to Directive 2003/87/EC of the European Parliament and of the Council, Decisions No 280/2004/EC and No 406/2009/EC of the European Parliament and of the Council and repealing Commission Regulations No 920/2010 and No 1193/201, [2013] OJ, L 122/1; EU, Commission Decision 2010/634 of 22 October 2010 adjusting the Union-wide quantity of allowances to be issued under the Union Scheme for 2013 and repealing Decision 2010/384/EU, [2010] OJ, L 279/34; Pohlmann, ibid at 344 \& 353; Pereira \& Jourdain, supra note 334 at 167-168; and Carlame, supra note 179 at 173.

${ }^{339}$ EU ETS Policy, supra note 336; Pohlmann, ibid at 355 \& 358; and Articles 10 of the ETS Directive, ibid.

${ }^{340}$ Articles 9 of the ETS Directive, ibid; Pereira \& Jourdain, supra note 334 at 167; and Pohlmann, ibid at 357.

341 EU ETS Policy, supra note 336; Pohlmann, ibid at 359-360; and Articles 6(2)(e) \& 12 of the ETS Directive, ibid. If a permit holder does not surrender sufficient allowances, they will be subject to penalties: Article 16(3) \& (4); and Pereira \& Jourdain, ibid at 169-170.

342 Pereira \& Jourdain, ibid at 169; Pohlmann, ibid at 346; EEA report, supra note 334 at 23; EU, Commission, Directorate-general for Climate Action, Guidance Document: The Monitoring and Reporting 
allowances per 1000 tonne-kilometres flown up to $82 \%$ of the aviation cap, while $15 \%$ is auctioned and $3 \%$ is kept on reserve. ${ }^{343}$ The cap is set at $95 \%$ of historical aviation emissions and is stable. ${ }^{344}$

While the impact of the ETS has been considerable despite ongoing problems, it still does not apply to some important GHG emitting sectors, most notably road transportation and agriculture. ${ }^{345}$ It is therefore reasonable to assume that the ETS impact on biofuels is somewhat limited. Nevertheless, there are some interactions between the ETS and the Renewable Energy Directive as the granting of allowances under the capand-trade system counts as a support scheme and consequently as financial support subject to the sustainability criteria. ${ }^{346}$ This has the effect of requiring installations and aircraft operators subject to the ETS Directive to respect the sustainability criteria if they wish to use biofuels as a tool to meet their allowances obligation, as non-mixed biofuels

Regulation - General guidance for Aircraft Operators, MRR Guidance document No 2, 16 July 2012, at 910; and Air Transport Association of America and Others v Secretary of State for Energy and Climate Change, C-366/10, [2011] ECR I-13833. Noncompliance can result in a revocation or suspension of the aircrafts operator authorization to operate: Article 16(5) of the ETS Directive, ibid; and Pohlmann, at 347.

${ }^{343}$ EU, Commission, Directorate-general for Climate Action, Allocation of aviation allowances in an EEAwide Emissions Trading System - Policy, 30 January 2014, online: ec.europa.eu < http://ec.europa.eu/clima/policies/transport/aviation/allowances/index en.htm >; Pohlmann, ibid at 347; and Articles 3a to $3 \mathrm{~g}$ of the ETS Directive, ibid.

${ }^{344}$ Pohlmann, ibid at 347; and Article 3c(2) of the ETS Directive, ibid. Historical aviation emissions were set by the EEA Joint Committee: European Economic Area, Decision of the EEA Joint Committee 87/2011 of 1 July 2011 amending Annex XX (Environment) to the EEA Agreement, EEA Supplement No 54, (2011) at 74; see also EU, Commission Decision 2011/149 of 7 March 2011 on historical aviation emissions pursuant to Article 3c(4) of Directive 2003/87/EC of the European Parliament and of the Council establishing a scheme for greenhouse gas emission allowance trading within the Community, [2011] OJ, L 61/42.

${ }^{345}$ Pohlmann, ibid at 349; EEA report, supra note 334; and Tim Laing et al, Assessing the effectiveness of the EU Emissions Trading System, Centre for Climate Change Economics and Policy Working Paper No 126, Grantham Research Institute on Climate Change and the Environment Working Paper No 106, January 2013.

${ }^{346}$ Preamble at Recital 2 of EU, Commission Regulation 601/2012 of 21 June 2012 on the monitoring and reporting of greenhouse gas emissions pursuant to Directive 2003/87/EC of the European Parliament and of the Council, [2012] OJ, L 181/30 [MRR]; and Article 17(1)(c) of the Renewable Energy Directive, supra note 180. 
have an ETS emission factor of zero. ${ }^{347}$ Biofuels not complying with the sustainability criteria will be considered, for the purpose of the ETS Directive, as fossil fuels. ${ }^{348}$ This linkage of provisions thus ensures that the ETS does not act as a market for "unsustainable" biofuels, and creates further incentives for the production and use of sustainable biofuels.

\subsubsection{Energy Efficiency}

Along with the 2020 EU-wide goals of a $20 \%$ GHG emissions reduction from the 1990 baseline and the $20 \%$ target for renewable energy use, the EU adopted the objective of a $20 \%$ improvement in energy efficiency. ${ }^{349}$ Energy efficiency can have an enormous impact on GHG emissions reduction in a cost effective manner. ${ }^{350}$ More specifically, energy efficiency measures can affect biofuels since the Renewable Energy Directive targets are based on a proportion of final energy consumption, and thus by lowering final consumption we reduce the amount of biofuels needed to meet the targets. ${ }^{351}$ To reach

\footnotetext{
${ }^{347}$ Articles 38 of the MRR, ibid.

${ }^{348}$ EU, Commission, Directorate-general for Climate Action, Guidance Document: Biomass issues in the EU ETS, MRR Guidance document No 3, 17 October 2012.

${ }^{349}$ EU, Communication from the Commission on a proposal for a Decision of the European Parliament and of the Council on a General Union Environment Action Programme to 2020: Living well, within the limits of our planet, 29 November 2012, COM(2012) 710 final; EU, Commission, Directorate-general for Climate Action, The 2020 climate and energy package - policy, 30 January 2014, online: ec.europa.eu < http://ec.europa.eu/clima/policies/strategies/2020/index_en.htm >; EC, Communication from the Commission on an Action Plan for Energy Efficiency: Realising the Potential, 19 October 2006, COM(2006) 545; EC, Communication from the Commission: 2020 by 2020 - Europe's climate change opportunity, 23 January 2008, COM(2008) 30; EU, Communication from the Commission: Energy 2020 A strategy for competitive, sustainable and secure energy, 10 November 2010, COM(2010) 639; and EU, Communication from the Commission on A policy framework for climate and energy in the period from 2020 to 2030, 22 January 2014, $\operatorname{COM}(2014) 15$. Contrary to the other two targets, the energy efficiency target is only a policy goal and is not legally binding: EU, Communication from the Commission on Implementing the Energy Efficiency Directive - Commission Guidance, 6 November 2013, COM(2013) 762 at 2 [EED Commission Guidance].

${ }^{350}$ EU, Communication from the Commission: Energy Efficiency Plan 2011, 8 March 2011, COM(2011) 109 at 2; and de Cendra de Larragan, supra note 216 at 58.

${ }^{351}$ EU, Commission Staff Working Document Accompanying the document Renewable energy progress report, 27 March 2013, SWD(2013) 102 at 7.
} 
this goal, the EU adopted in October 2012 the Energy Efficiency Directive. ${ }^{352}$ The Directive tries to bring together the plethora of energy efficiency legislation and create a comprehensive framework to remedy the shortcomings of previous energy efficiency policies. ${ }^{353}$ It establishes an obligation for each member state to set an indicative national energy efficiency target expressed in terms of an absolute level of primary energy consumption and final energy consumption in $2020 .{ }^{354}$ Member states are also required to submit a long-term strategy for building renovation and to set the example by renovating $3 \%$ of publicly owned and occupied building every year according to the standard set by the Building Energy Performance Directive. ${ }^{355}$ Moreover, public procurement rules have to be put in place to ensure that governments buy products, services and buildings with high energy efficiency performance. ${ }^{356}$

Energy providers are not overlooked by the Energy Efficiency Directive as it imposes on them an energy savings obligation of at least $1.5 \%$ a year (based on energy sales to final consumers) either through the mandatory energy efficiency obligation schemes or through alternative policies adopted by member states such as energy or

\footnotetext{
${ }^{352}$ Article 1(1) of EU, Directive 2012/27 of the European Parliament and of the Council of 25 October 2012 on energy efficiency, amending Directives 2009/125/EC and 2010/30/EU and repealing Directives 2004/8/EC and 2006/32/EC, [2012] OJ, L 315/1 [Energy Efficiency Directive]; and EED Commission Guidance, supra note 349 at 2.

${ }^{353}$ Preamble at Recitals 8, 12, 17, 32, 58 \& 59 of the Energy Efficiency Directive, ibid; EU, Commission, Impact Assessment accompanying the document Directive of the European Parliament and of the Council on energy efficiency and amending and subsequently repealing Directive 2004/8 and 2006/32, 22 June 2011, SEC(2011) 779 at 8, 12 \& 13; and de Cendra de Larragan, supra note 216 at 58-59. The Directive sets minimum requirements that member states are free to enhance: Article 1(2) of the Energy Efficiency Directive.

${ }^{354}$ Article 3 of the Energy Efficiency Directive, ibid.

355 Articles 4 \& 5, ibid; Article 4 of the EU, Directive 2010/31 of the European Parliament and of the Council of 19 May 2010 on the energy performance of buildings, [2010] OJ, L 153/13 [Building Energy Performance Directive]; Matthew Leach \& Sandip Deshmukh, "Sustainable Energy Law and Policy", in Karen E Makuch \& Ricardo Pereira, eds, Environmental and Energy Law (Chichester, UK: WileyBlackwell, 2012), at 126-127; and de Cendra de Larragan, supra note 2016 at 60-61.

${ }^{356}$ Article 6 of the Energy Efficiency Directive, ibid.
} 
carbon taxes, fiscal incentives, energy efficiency standards, and regulations. ${ }^{357}$ The Energy Efficiency Directive creates a complex web of hard and soft obligations, and gives considerable latitude to member states in implementing the energy efficiency regime. ${ }^{358}$ It remains uncertain how effective the Directive will be without clear legally binding obligations. $^{359}$

\subsection{Agricultural and Biodiversity Regulations}

The complex and abundant environmental policies of the EU go beyond matter of climate change and offer further protection that can influence the sustainability of biofuels production. Chief among them are legislation dealing with agricultural pollution and with the protection of biodiversity. The legislation covered in this subsection is partially integrated into the Renewable Energy Directive via its reference to certain provisions and Annexes of Council Regulation 73/2009. ${ }^{360}$

\subsubsection{Biodiversity Protection}

The two main directives protecting biodiversity in the EU are the interdependent Birds Directive and Habitats Directive. ${ }^{361}$ The Birds Directive establishes a regime of

\footnotetext{
357 Article 7 of the Energy Efficiency Directive, ibid; and EU, Commission, Guidance note on Directive 2012/27/EU on energy efficiency, amending Directives 2009/125/EC and 2010/30/EC, and repealing Directives 2004/8/EC and 2006/32/EC - Article 7: Energy efficiency obligation schemes, 6 November 2013, SWD(2013) 451 at 9.

${ }^{358}$ See also EC, Directive 2009/125 of the European Parliament and of the Council of 21 October 2009 establishing a framework for the setting of ecodesign requirements for energy-related products, [2009] OJ, L 285/10; Building Energy Performance Directive, supra note 355; and de Cendra de Larragan, supra note 216 at $62-64$.

${ }^{359}$ See de Cendra de Larragan, ibid at 61.

${ }^{360}$ Article 17(6) of the Renewable Energy Directive, supra note 180.

${ }^{361}$ EC, Directive 2009/147 of the European Parliament and of the Council of 30 November 2009 on the conservation of wild birds, [2009] OJ, L 20/7, as amended by Directive 2013/17 (consolidated version of 2013) [Birds Directive] (formally EEC, Council Directive 79/409 of 2 April 1979 on the conservation of wild birds, [1979] OJ, L 103/1); EEC, Council Directive 92/43 of 21 May 1992 on the conservation of natural habitats and of wild fauna and flora, [1992] OJ, L 206/7, as amended by Directives 97/62,
} 
minimum protection geared at maintaining wild bird species population "at a level which corresponds in particular to ecological, scientific and cultural requirements, while taking account of economic and recreational requirements, or to adapt the population of these species to that level" through the protection of all birds, and their eggs, nests and habitats. ${ }^{362}$ The obligations regarding the conservation of habitats are found in Articles 3 and 4. Member states have to ensure the sufficiency of birds' habitats - both in area and in diversity - by creating protected areas and new habitats, maintaining and managing all habitats according to their ecological needs, and by re-establishing destroyed habitats. ${ }^{363}$ Moreover, endangered, vulnerable and rare species listed in Annex I are to receive enhanced protection of their habitats including by being designated as special protection areas. $^{364}$

The Habitats Directive is broader in scope as it encompasses natural habitats of all types of species, but is more restrictive at the same time as it only covers species of

2006/105 \& 2013/17, Regulation 1882/2003, the Act of Accession of Austria, Sweden and Finland, and the Act concerning the conditions of accession of the Czech Republic, the Republic of Estonia, the Republic of Cyprus, the Republic of Latvia, the Republic of Lithuania, the Republic of Hungary, the Republic of Malta, the Republic of Poland, the Republic of Slovenia and the Slovak Republic (consolidated version of 2013) [Habitats Directive]; and Nicolas de Sadeleer, "EC Law and Biodiversity", in Richard Macrory, ed, Reflections on 30 Years of EU Environmental Law - A High Level of Protection? (Groningen: Europa Law Publishing, 2006) at 361.

${ }^{362}$ Articles 1, 2 \& 14 of the Birds Directive, ibid; Jans \& Vedder, supra note 216 at 452-453; and de Sadeleer, ibid at 363. The economic and recreational requirements portion of Article 2 was deemed a statement of legislative purpose and not a mean of derogation to the regime: Commission v Belgium, C247/85, [1987] ECR 3029; Commission v Italy, C-262/85, [1987] ECR 3073; Commission v Germany, C57/89, [1991] ECR I-883; Commission v Spain, C-355/90, [1993] ECR I-4221; Association pour la protection des animaux sauvages v Préfet de Maine-et-Loire and Préfet de la Loire-Atlantique, C-435/92, [1994] I-67; $R v$ Secretary of State for the Environment, ex parte Royal Society for the Protection of Birds, C-44/95, [1996] ECR I-3805; and de Sadeleer, at 362.

${ }^{363}$ Article 3 of the Birds Directive, ibid.

${ }^{364}$ Article 4, ibid; Commission v Spain, supra note 362; $R$ v Secretary of State for the Environment, supra note 362; Commission v Germany, supra note 362; Commission v Ireland, C-117/00, [2002] ECR I-5335; Commission v Austria, C-209/04, [2006] ECR I-2755; Commission v Netherlands, C-3/96, [1998] ECR I3031; Jans \& Vedder, supra note 216 at 453-456; and Davies, supra note 179at 127-133. 
Community interest. ${ }^{365}$ Member states are required to monitor the conservation status of these habitats. ${ }^{366}$ The Directive defines species of Community interest as species that are endangered, vulnerable, rare, or endemic, and requiring particular attention. ${ }^{367}$ It creates the Natura 2000 ecological network of special areas of conservation composed of Annex I habitats, of Annex II species habitats, and the Birds Directive special protection areas. ${ }^{368}$ Member states must submit a list of sites meeting the Natura 2000 criteria to the Commission. ${ }^{369}$ From this list the Commission, in tandem with each member state, selects habitats of Community importance which are then designated by member states as special areas of conservation. ${ }^{370}$ For each special area, member states must adopt necessary habitat conservation measures. ${ }^{371}$ Member states must also avoid habitats' deterioration, must avoid disturbing species that inhabit them, and must conduct an appropriate assessment of any plan or project not connected with the site's management that is likely to have a significant effect on the site. ${ }^{372}$ The habitat protection regimes of both Directives overlap, can be quite complex, and leave considerable latitude to member states. Delays in their implementation have been noted, as well as weak to nonexistent

\footnotetext{
${ }^{365}$ Article 2 of the Habitats Directive, supra note 361; and de Sadeleer, supra note 361 at 363.

${ }^{366}$ Article 11 of the Habitats Directive, ibid.

${ }^{367}$ Article 1(g), ibid.

368 Article 3, ibid; Commission v Germany, C-71/99, [2001] ECR I-5811; and Davies, supra note 179 at $133 \& 136-140$.

${ }^{369}$ Article 4(1) of the Habitats Directive, ibid. Economic, social or cultural issues cannot be part of the criteria member states use to draw up their lists: The Queen $v$ Secretary of State for the Environment, Transport and the Regions, ex parte First Corporate Shipping, C-371/98, [2000] ECR I-9235; and Davies, ibid at $138-139$.

${ }^{370}$ Article 4(2)\&(4) and Annex III of the Habitats Directive, ibid; Commission v United Kingdom, C-6/04, [2005] ECR I-9017; Jans \& Vedder, supra note 216 at 459-460; and Davies, ibid at 140-151.

${ }^{371}$ Article 6(1) of the Habitats Directive, ibid.

${ }^{372}$ Article 6(2) (3) \& (4), ibid; Commission v Greece, C-103/00, [2002] ECR I-1147; Waddenvereniging and Vogelsbeschermingvereniging $v$ Staatssecretaris van Landbouw, Natuurbeheer en Visserij, C-127/02, [2004] ECR I-7405; Commission v Italy, C-304/05, [2007] ECR I-7495; Davies, supra note 179 at 134; and Jans \& Vedder, supra note 216 at 460-462.
} 
protection of listed sites. ${ }^{373}$ Nonetheless, habitat protection, even if limited, is a crucial piece of biofuels sustainability as land-use change triggered by agricultural production of biofuels feedstocks can have serious negative impacts on biodiversity.

\subsubsection{Agricultural Pollution}

In addition to direct and indirect land-use change, agricultural production engenders various forms of pollution. Two Directives dealing with pollution caused by agriculture are referred to in Council Regulation 73/2009: the Water Framework Directive (by reference of its predecessor the Groundwater Directive), and the Nitrates Directive. ${ }^{374}$ The Water Framework Directive deals with the protection of inland surface waters, transitional waters, coastal waters and groundwater in the EU. ${ }^{375}$ The Directive focuses on the management of river basins divided into districts by member states. ${ }^{376}$ Each district is required to establish a river basin management plan. ${ }^{377}$ Pollution point sources are subject to emissions control supplemented with environmental quality

\footnotetext{
373 de Sadeleer, supra note 361 at 364; Davies, ibid at 139-140; Commission v Spain, supra note 362; Commission v Netherlands, supra note 364; Commission v France, C-220/99, [2001] ECR I-5831; Commission v Ireland, C-67/99, [2001] ECR I-5757; Commission v France, C-202/01, [2002] ECR I11019; and Commission v France, C-96/98, [1999] ECR I-8531.

${ }^{374}$ EC, Directive 2000/60 of the European Parliament and of the Council of 23 October 2000 establishing a framework for Community action in the field of water policy, [2000] OJ, L 327/1, as amended by Decision 2455/2001, and Directives 2008/32, 2008/105, 2009/31 \& 2013/39 (consolidated version of 2013) [Water Framework Directive]; and EEC, Council Directive 91/676 of 12 December 1991 concerning the protection of waters against pollution caused by nitrates from agricultural sources, [1991] OJ, L 375/1, as amended by Regulations 1882/2003 \& 1137/2008 (consolidated version of 2008) [Nitrates Directive].

${ }^{375}$ Preamble and Article 1 of the Water Framework Directive, ibid; Jans \& Vedder, supra note 216 at 348; Claudia Olazabal, "Community Legislation on Water Protection: An Assessment of its Evolution and Possible Future", in Marco Onida, ed, Europe and the Environment - Legal Essays in Honour of Ludwig Krämer (Groningen: Europa Law Publishing, 2004) at 166 \& 168; and EU, Commission, Directorategeneral for the Environment, Introduction to the new EU Water Framework Directive, 20 February 2014, online: ec.europa.eu < http://ec.europa.eu/environment/water/water-framework/info/intro_en.htm >.

${ }^{376}$ Article 3(1)(2)\&(3) of the Water Framework Directive, ibid; Jans \& Vedder, ibid at 348-349; and Olazabal, ibid at 166.

377 Articles 4(1), 11 \& 13 of the Water Framework Directive, ibid; Brian Jack, Agriculture and EU Environmental Law (Burlington, VT: Ashgate Publishing, 2009) at 184; and Jans \& Vedder, ibid at 349350 .
} 
standards set up by member states, while diffuse sources are subject to specific regimes such as the Nitrates Directive. ${ }^{378}$ The districts' administrative authorities are directed to review the environmental and economic impacts of human activities on bodies of water every 6 years after an initial grace period of 13 years, and must monitor the status of these bodies of water. ${ }^{379}$ Finally, the Parliament and the Council are tasked to adopt specific measures dealing with various forms of water pollution. ${ }^{380}$ The regime created by the Water Framework Directive is far from simple considering the number of exceptions and environmental objectives, which leaves the question of its effectiveness open. ${ }^{381}$

The Nitrates Directive aims at reducing and preventing water pollution by nitrates from agricultural sources. ${ }^{382}$ It requires member states to identify vulnerable zones, which are zones that drain into waters susceptible to pollution. ${ }^{383}$ Members have to subsequently adopt an action programme for each vulnerable zone that includes rules on periods when fertilizer application is prohibited, the capacity of storage vessels for livestock manure, limitations on fertilizers application based on the characteristic of the vulnerable zone, and a maximum amount of manure of $170 \mathrm{~kg} \mathrm{~N}$ per hectare for each farm or livestock

\footnotetext{
${ }^{378}$ Article 10 of the Water Framework Directive, ibid; and Jans \& Vedder, ibid at 353.

${ }^{379}$ Articles 5 \& 8 of the Water Framework Directive, ibid.

${ }^{380}$ Articles 16 \& 17, ibid; and Jans \& Vedder, supra note 216 at 354-355.

${ }^{381}$ Jans \& Vedder, ibid at 340-352; and Commission v Luxembourg, C-32/05, [2006] ECR I-11323.

382 Article 1 of the Nitrates Directive, supra note 374.

383 Article 3, ibid; Commission v Ireland, C-396/01, [2004] ECR I-2315; Commission v France, C-258/00, [2002] ECR I-5959; Commission v France, C-280/02, [2004] ECR I-8573; The Queen v Minister of Agriculture, Fisheries and Food, ex parte Standley, C-293/97, [1999] ECR I-2603; Commission v United Kingdom, C-69/99, [2000] ECR I-10979; Commission v Belgium, C-221/03, [2005] ECR I-8307; Jack, supra note 377 at 173-182; and Jans \& Vedder, supra note 216 at 369.
} 
unit. ${ }^{384}$ The Nitrates Directive also compels member states to adopt a voluntary code of good agricultural practices. ${ }^{385}$

\section{Conclusion}

The constitutional structure of the EU evolved considerably in the past decades. This structure, unusual compared to national ones, limits in part the power of the EU regarding the regulation of biofuels production. Although the EU may possess some of the traditional state institutions such as a Parliament and an executive, member states, which are sovereign nations, still hold considerable power over the adoption and implementation of EU legislation. Nevertheless, the EU has come to possess considerable powers to deal with environmental issues - notably through its standards setting power and now specifically with climate change, and to some extent with energy issues. It has used this power to adopt an impressive array of environmental legislation and policies dealing with a variety of topics. Among them is the ambitious climate change programme aimed at reducing GHG emissions by $20 \%$ in 2020 compared to the 1990 level, and by even more subsequently. ${ }^{386}$

The Renewable Energy Directive was adopted in 2009 as a part of the climate change programme. It mandates a minimum renewable energy proportion of $20 \%$ of energy use in the EU, and of $10 \%$ in the transport sector specifically. To ensure that biofuels used to meet the transport sector energy goal do not undermine the sustainability

\footnotetext{
${ }^{384}$ Article 5 and Annex III of the Nitrates Directive, ibid; Commission v Netherlands, C-322/00, [2003] ECR I-11267; Commission v Germany, C-161/00, [2002] ECR I-2753; and Jack, ibid at 173-174.

${ }^{385}$ Article 4 of the Nitrates Directive, ibid.

${ }^{386} 80$ to $95 \%$ GHGs reduction by 2050: EU, Communication from the Commission: A Roadmap for moving to a competitive low carbon economy in 2050, 8 March 2011, COM(2011) 112.
} 
purpose of the Directive, the EU included sustainability criteria for biofuels. These criteria, applicable to all biofuels regardless of their origin save for one, deal with GHG emissions savings, biodiversity and land-use change. Compliance is ensured by Commission approved voluntary certification schemes.

The Renewable Energy Directive is, however, not the only legislation affecting biofuels. Other parts of the climate change programme can influence the sustainability of biofuels production. The Fuel Quality Directive establishes a 6 to $10 \%$ decarbonisation targets for gasoline and diesel. Biofuels used to reach this target are subject to the same sustainability criteria as those found in the Renewable Energy Directive. The ETS Directive and the Energy Efficiency Directive can also impact biofuels production as they create schemes that favour clean or low GHG emitting fuels, and that encourage energy conservation to diminish overall energy consumption. Biofuels sustainability is further impacted by environmental legislation dealing with broader environmental problems such as the Birds Directive, the Habitats Directive, the Water Framework Directive, and the Nitrates Directive. Finally, fiscal duties imposed through the Energy Taxation Directive and customs regulations can influence the biofuels market.

It is within this legislative framework that the Renewable Energy Directive operates. In the next chapter, after establishing the impacts of EU biofuels production, I assess the sustainability of the EU biofuels regulatory framework with particular emphasis on the Directive using the approach described in the previous chapter. 


\section{Chapter 4 - Shades of Green: Assessing the Sustainability of the EU Biofuels Regime}

\section{Introduction}

“The incentives provided for in this Directive will encourage increased production of biofuels and bioliquids worldwide." 387 The inclusion of this sentence in the Renewable Energy Directive was not simply a statement of desired outcome as the EU's influence on worldwide biofuels production is grounded in facts. With $19 \%$ of global consumption of biofuels in 2011, the EU represents an important player and in the global biofuels market. ${ }^{388}$ In 2014, renewables represented only $5.1 \%$ of energy consumption in the transport sector. ${ }^{389}$ By 2020, with the Directive's $10 \%$ target, that number will have doubled and thus expanded significantly the biofuels industry in the EU. While the EU had economic and energy security aims justifying the adoption of the Directive, it was also cognizant that these goals had to be achieved in a sustainable manner. ${ }^{390}$ It went as far as to include in the Preamble that "[c]onsumers in the Community would, in addition, find it morally unacceptable that their increased use of biofuels and bioliquids could have the effect of destroying biodiverse lands." 391 Even the European Council stated that a

\footnotetext{
${ }^{387}$ Preamble at Recital 74 of EC, Directive 2009/28 of the European Parliament and of the Council of 23 April 2009 on the promotion of the use of energy from renewable sources and amending and subsequently repealing Directives 2001/77/EC and 2003/30/EC, [2009] OJ, L 140/16 [Renewable Energy Directive].

${ }^{388}$ Chris Charles et al, Biofuels - At What Cost? A review of costs and benefits of EU biofuel policies (Winnipeg: International Institute for Sustainable Development, 2013) at 18.

${ }^{389}$ IEA, Energy Policies of IEA Countries - European Union 2014 (Paris: International Energy Agency, 2014) at 227.

${ }^{390}$ Preamble at Recital 3 and Article 1 of the Renewable Energy Directive, supra note 387.

${ }^{391}$ Preamble at Recital 69, ibid.
} 
mandatory target was appropriate, "subject to production being sustainable, [and] second-generation biofuels becoming commercially available ..." [emphasis added]. ${ }^{392}$

Did the EU take the appropriate route to achieve the sustainable development of biofuels? Was the target actually appropriate? This chapter aims at answering these questions by bringing this thesis full circle. While the previous chapters have defined the theory, approach and object of this thesis (the Directive and its framework), this chapter completes the picture by firstly providing general data on the sustainability of biofuels consumed in the EU. It establishes the lifecycle assessment of impacts through general empirical data on biofuels consumed in the EU. The chapter also adds to this data by summarizing particular lifecycle assessment studies for each generation of EU biofuels. It concludes with the final analysis of the principled lifecycle assessment: an assessment based on some of the principles of sustainable development.

\section{The Underlying Sustainability: Assessing the Impacts of Biofuels}

While the purpose of this thesis is to assess the sustainability of the Renewable Energy Directive's biofuels provisions, it is first necessary to understand the impacts of the underlying product that the Directive seeks to regulate. To determine the efficacy of the Directive's sustainability criteria, one must look at the known environmental and socio-economic impacts of EU biofuels to see if the criteria address them properly. The previous chapter described the regulatory framework of the principled lifecycle assessment this thesis is undertaking. In this section, I summarize the data used for my analysis; in other words the impacts of biofuels consumed in the EU. I will firstly

${ }^{392}$ EC, Council, Presidency Conclusions, Brussels, 2 May 2007, Doc 7224/1/07 REV 1, at 21. 
describe the environmental impacts of EU biofuels. I then follow up on discussing their socio-economic impacts.

\subsection{The Green Haemorrhage: Environmental Impacts}

Biofuels have been used in many countries as part of their climate change mitigation strategy and overall environmental and energy policy. As stated multiple times in this thesis, their potential lies as a replacement to fossil fuels. However, as discussed in the introductory chapter, many doubts have been raised as to the actual environmental sustainability of biofuels. It is not obvious anymore that they do, in fact, reduce GHG emissions compared to fossil fuels. Furthermore, many biofuels, especially first generation biofuels, have severe impacts on the natural environment through water pollution and loss of biodiversity, amongst others. The underlying question is: can biofuels truly be considered environmentally friendly products? Even if they provide some benefits, are biofuels worth their environmental cost? The purpose of this subsection is to partly elucidate those questions through outlining the impacts of EU biofuels, mainly those related to GHG emissions, energy security, water quality and biodiversity.

\subsubsection{The Main Issue: GHG Emissions and Energy Concerns}

Perhaps the most important environmental impact of biofuels is GHG emissions, since it is arguable that without a positive impact on climate change mitigation, policies promoting the use of biofuels are illegitimate (at least environmentally speaking). Thankfully there are many sources of data on biofuels' GHG emissions, including the EU itself. The Commission, using the default values for feedstocks of Annex V of the 
Renewable Energy Directive and member states reported data, estimated the GHG emissions savings in transport for 2010 due to biofuels. Savings are calculated by comparing a particular biofuel to its fossil fuel equivalent and thus represent the amount of GHGs not emitted (saved) by using biofuels instead of fossil fuels. This estimate is of 22.6 to $25.5 \mathrm{Mt} \mathrm{CO}_{2}$ eq (equivalent in million tons of carbon dioxide). ${ }^{393}$ Using the latest data available for each member state I estimate that the savings are of approximately 31.2 Mt $\mathrm{CO}_{2}$ eq for the year 2012. ${ }^{394}$ The Commission predicts that emission savings will rise to $48 \mathrm{Mt} \mathrm{CO}_{2}$ eq in $2020 .{ }^{395}$ However, none of these numbers includes GHG emissions caused by ILUC. ${ }^{396}$ ILUC is a major uncertainty in GHG emissions savings calculations that needs to be resolved in order to obtain complete data. ${ }^{397}$

Using the above Commission's estimates, Charles et al created scenarios to approximate the GHG emissions (including ILUC) produced by biofuels used for transportation depending on the different caps for agricultural biofuels by $2020 .{ }^{398}$ The caps represent the transport sector energy consumption share of first generation biofuels. With the original 5\% cap found in the Commission Proposal for a Directive amending

${ }^{393}$ EU, Commission Staff Working Document Accompanying the document Renewable energy progress report, 27 March 2013, SWD(2013) 102, at 27 [2013 Progress Report SWD].

${ }^{394}$ For individual member states reports see EU, Commission, Directorate-General for Energy, Renewable energy: 2013 Progress reports, online: ec.europa.eu http://ec.europa.eu/energy/renewables/reports/2013 en.htm > [Member states reports]. Germany did not have a 2013 report and therefore the data from 2010 was used for the estimate: Federal Republic of Germany, Progress Report under Article 22 of Directive 2009/28/EC on Promotion of the Use of Energy from Renewable Sources, online: < http://ec.europa.eu/energy/renewables/reports/2011_en.htm >.

3952013 Progress Report SWD, supra note 393 at 27.

396 ECOFYS et al, Renewable energy progress and biofuels sustainability, Report submitted to the European Commission, September 2012, at tables 54-55 [ECOFYS et al].

397 OECD \& IEA, Sustainable Production of Second-Generation Biofuels - Potential and perspectives in major economies and developing countries (Paris: International Energy Agency, 2010) at 83; EEA, EU bioenergy potential from a resource-efficiency perspective, EEA Report No 6/2013 (Copenhagen: European Environment Agency, 2013) at 29-30 [EEA 2013]; and Bettina Kretschmer, The land-use implications of EU bioenergy policy: Going beyond ILUC (London: Institute for European Environmental Policy, 2011).

${ }^{398}$ Charles et al, supra note 388 at $81-84$. I used the median values found in the report. 
the Fuel Quality Directive and the Renewable Energy Directive, ${ }^{399}$ the GHG emissions are of $59 \mathrm{Mt} \mathrm{CO}_{2}$ eq. With the $7 \%$ cap of the ILUC Directive, this number is $82.6 \mathrm{Mt} \mathrm{CO}_{2}$ eq. Without any cap, GHG emissions are estimated to be $118 \mathrm{Mt} \mathrm{CO}_{2}$ eq. With the $5 \%$ cap the GHG emissions savings are only of $5.3 \mathrm{Mt} \mathrm{CO}_{2}$ eq, a significant discrepancy when compared to the Commission's estimate of $48 \mathrm{Mt} \mathrm{CO}_{2}$ eq. This is probably due to ILUC estimates as the impact of ILUC can negate the GHG emissions saving potential of biofuels, which puts into question the validity of any numbers obtained without considering ILUC. ${ }^{400}$

Additionally, feedstocks grown with fertilisers containing nitrate have a higher GHG emissions potential. This is the result of the nitrate leaching into the groundwater. The water eventually comes back to the surface and evaporates, releasing nitrous oxide $\left(\mathrm{N}_{2} \mathrm{O}\right)$ which has 300 times the global warming potential of $\mathrm{CO}_{2} \cdot{ }^{401}$ A Swedish case study has shown that crops grown on nitrate-intensive soils have a 50\% chance of not meeting the current minimum EU GHG emissions savings criterion of $35 \% .^{402}$

The effect of biofuels on EU energy security is still unknown. ${ }^{403}$ Some studies have shown that the use of biofuels will increase the energy security of the EU, while others have indicated that it will not contribute to the long-term energy security of the

\footnotetext{
${ }^{399}$ EU, Commission, Proposal for a Directive of the European Parliament and of the Council amending Directive 98/70/EC relating to the quality of petrol and diesel fuels and amending Directive 2009/28/EC on the promotion of the use of energy from renewable sources, 17 October 2012, $\operatorname{COM(2012)~595,~at~} 14$.

${ }^{400}$ EEA 2013, supra note 397 at 44; and Kretschmer, supra note 397.

${ }^{401}$ Charles et al, supra note 388 at 58.

402 Åsa Kasimir Klemedtsson and Keith A Smith, "The significance of nitrous oxide emission due to cropping of grain for biofuel production: a Swedish perspective" (2011) 8 Biogeosciences 3581 .

${ }^{403}$ Energy security is "the uninterrupted physical availability of energy products on the market, at a price which is affordable for all consumers": EU, Commission, Green Paper: Towards a European strategy for the security of energy supply, Directorate-General for Energy and Transport, 29 November 2000, $\operatorname{COM}(2000) 769$ at 3 .
} 
EU. ${ }^{404}$ The energy security impact will greatly depend on the source of feedstocks and/or biofuels (the reliance on foreign markets) and the volatility of feedstocks/biofuels prices. Biofuels consumed in the EU are made of feedstocks of which $36 \%$ are imported, mainly from Argentina (9.7\%), Indonesia (6.6\%), Brazil (5.3\%), United States (3\%), Canada (2.4\%), Ukraine (2.3\%), Malaysia (1.7\%) and Paraguay (1.3\%). ${ }^{405}$ Anticipated imports for 2020 amount to $44 \%$ of bioethanol and $36 \%$ of biodiesel consumed. ${ }^{406}$ The energy security potential of biofuels (the ability to be energy self-sufficient and to have internal control over energy sources) for the EU is thus not fully achieved and will not be for the foreseeable future since the EU will continue to rely on foreign markets to meet its bioenergy needs.

\subsubsection{Other Environmental Aspects: Biodiversity and Water Quality}

Since the main source of feedstocks for EU biofuels is agricultural crops (first generation), most of the environmental impacts of biofuels on water quality and biodiversity are similar to those of the agroindustry ${ }^{407}$ According to the 2013 biannual member states' progress report mandated by Article 22 of the Renewable Energy Directive, eleven member states, including large producer states like France and Spain, had not conducted any assessment on the impacts of biofuels production on biodiversity and water quality. ${ }^{408}$ Only Bulgaria, Lithuania, Poland and Sweden conducted such

\footnotetext{
${ }^{404}$ Charles et al, supra note 388 at 87-88.

${ }^{405}$ EU, Commission, Renewable energy progress report, 27 March 2013, $\operatorname{COM(2013)~} 175$ at 11 [2013 Progress Report].

${ }^{406}$ Bettina Kretschmer, Catherine Bowyer \& Allan Buckwell, EU Biofuel Use and Agricultural Commodity Prices: A Review of the Evidence Base (London: Institute for European Environmental Policy, 2012) at 10 [Kretschmer et al].

4072013 Progress Report SWD, supra note 393 at 18; and Shabbir Gheewala et al, The Bioenergy and Water Nexus (United Nations Environment Programme, Oeko-Institut and IEA Bioenergy Task 43, 2011) at 41 .

${ }^{408}$ Member states reports, supra note 394.
} 
impact assessments, while Austria and Germany's assessments were still ongoing. ${ }^{409}$ The rest of the member states either rely on partial assessments, such as the United Kingdom who conducted a study on biofuels production impacts on birds, or affirm that biofuels production is minimal and that impacts are thus negligible. Like previous reports, the most recent progress reports give little information and data on land-use changes. ${ }^{410}$ Most states claim that no land-use change has occurred, but provide no studies or data to support it. In 2010, it was estimated that 2.2 million hectares of additional land were needed in the EU to meet biofuels demands; 13.6 million additional hectares were needed worldwide. ${ }^{411}$ The area of land currently used to grow feedstocks in the EU is larger than the total surface of Belgium. ${ }^{412}$ It is therefore hard to believe that current biofuels production is having no land-use impact in the EU.

The Commission combined the three land-change criteria and evaluated the risk of land-use change on biodiversity in the EU and major biofuels exporters. ${ }^{413}$ Risk of land-use change is estimated as low for the EU as a whole and for all of the member states except Spain and Poland which have a moderate risk. The risk rises to medium for Argentina and Canada, and to high for Brazil, Russia and the United States (hereafter the US). The risk remains low for Indonesia, Malaysia, Paraguay and Ukraine. The Commission also looked at the risk due to low legal protections associated with biodiversity. This risk is high for Argentina, Paraguay and Ukraine, medium for Brazil,

\footnotetext{
${ }^{409}$ Germany has not submitted a 2013 progress report but a study was in progress in 2010: 2013 Progress Report SWD, supra note 393 at 18. I assume the study is still in progress considering the lack of report.

${ }^{410} 2013$ Progress Report SWD, ibid at 21.

${ }^{411}$ ECOFYS et al, supra note 396 at 241.

${ }^{412}$ Charles et al, supra note 388 at 41.

${ }^{413} 2013$ Progress Report SWD, supra note 393 at 27-28. The risk for exporter states only considers the impact of EU demands and not of the global demand for biofuels. Therefore one must read these risks cautiously as cumulative impacts on biodiversity may be greater in reality.
} 
Canada, Malaysia and the US, and low for Indonesia and Russia. Indonesia is the only non-EU country with low risks in both categories. The Commission concludes that the EU demand for biofuels poses a modest risk of land conversion for forests, including rainforests, and a high one for savannah/shrubland and grassland ecosystems. ${ }^{414}$

As hinted by the Commission's data, the impact of biofuels on biodiversity is far from negligible. From 2003 to 2009, around 55000 ha of grassland were lost due to maize production for biofuels in Europe. ${ }^{415}$ Loss of grassland has already occurred in the United Kingdom, Germany and Central Europe. ${ }^{416}$ Studies have shown that the biofuels production in Brazil has already resulted in deforestation, although some progress was made through zoning regulation. ${ }^{417}$ They also indicate that biofuels production in Malaysia resulted in the loss of peatland, the loss of tropical forest, rainforest, and threats to endangered species such as the orang-utan of Borneo. ${ }^{418}$ Most troubling is the lack of research on the specific impacts of biofuels on biodiversity. ${ }^{419}$ While it is hard to estimate this impact, especially with ILUC, it is clear that continued use of first generation biofuels will increase the rate in loss of fauna and flora biodiversity. ${ }^{420}$ The situation is especially troubling due to the fact that a high proportion of protected species and

\footnotetext{
4142013 Progress Report SWD, ibid at 28; Rocio Diaz-Chavez et al, Mandatory requirements in relation to air, soil, or water protection: analysis of need and feasibility, Final Report - Tasks 3 \& 4 (Utrecht: ECOFYS, 2013) at 54; and ECOFYS et al, supra note 396 at 267-268.

${ }^{415}$ Charles et al, supra note 388 at 62.

${ }^{416}$ Diaz-Chavez et al, supra note 414 at 54.

${ }^{417}$ Joyce Tait et al, Biofuels: ethical issues (London: Nuffield Council on Bioethics, 2011) at 35-36.

${ }^{418}$ Ibid at 40-41.

${ }^{419}$ Ben Allen et al, Space for energy crops - assessing the potential contribution to Europe's energy future (London: Institute for European Environmental Policy, 2014) at 22.

${ }^{420}$ Ibid at 23-24; Charles et al, supra note 388 at 63; and Annie Webb \& David Coates, Biofuels and Biodiversity, CBD Technical Series No 65 (Montréal: Secretariat of the Convention on Biological Diversity, 2012) at 7-8 \& 38-39.
} 
habitats in the EU are in unfavourable conditions and the underlying causes of biodiversity loss (including agricultural intensification) are not improving. ${ }^{421}$

Water quality impacts of biofuels include surface and groundwater contamination from fertilizers, pesticides and herbicides during feedstocks production, and processing and industrial effluents from biofuel refineries. ${ }^{422}$ Brazil (sugar cane), Indonesia (palm oil), Malaysia (palm oil), and the US (soybean and maize) are the jurisdictions with the highest water quality risks, mainly due to agricultural production, although all jurisdictions exporting biofuels/feedstocks to the EU have a high risk. ${ }^{423}$ The highest water quality impact from within the EU came from Polish wheat with a similar impact as Indonesian palm oil and Canadian rapeseed. A modest impact was also noted from Spanish wheat, French maize and rapeseed, and German rapeseed. ${ }^{424}$ As a reference, in 2010, biodiesel produced in the EU was made mostly from rapeseed (56\%), soybean (13\%) and palm oil (9\%); as for EU bioethanol, it was produced mainly from wheat (30\%), sugar beet (30\%) and maize (23\%). ${ }^{425}$ Lignocellulosic biofuels can also result in some water pollution as the use of chemicals is often needed in the refining process. ${ }^{426} \mathrm{~A}$ study notes, however, that governments seem generally willing to adopt better legislation and management practices in that field and notes a positive trend in the adoption of environmental legislation protecting water quality. ${ }^{427}$

\footnotetext{
${ }^{421}$ EEA, The European environment - state and outlook 2015: synthesis report (Copenhagen: European Environment Agency, 2015) at 56 [EEA 2015].

${ }^{422}$ ECOFYS et al, supra note 396 at 409; and Gheewala et al, supra note 407 at 41-43 \& 48-49.

${ }^{423}$ ECOFYS et al, ibid at 274 \& 410-413; Diaz-Chavez et al, supra note 414 at $42-48$ \& 72-73; and Tait et al, supra note 417 at $33 \& 35$. Brazilian sugarcane and US maize have, according to the ECOFYS study, the highest and fastest growing impact on water quality.

${ }^{424}$ ECOFYS et al, ibid at 274; and Diaz-Chavez et al, ibid at 68.

${ }^{425}$ ECOFYS et al, ibid at 202.

${ }^{426}$ Tait et al, supra note 417 at 53-54; and Gheewala et al, supra note 407 at 48-49.

${ }^{427}$ ECOFYS et al, supra note 396 at 275.
} 
Nutrient pollution, like nitrates, has decreased over the past decades in Europe, showing improvement in water quality protection. Eutrophication caused by water pollution remains a risk and an increase of agricultural activities caused by biofuels demands in the EU could hinder the reduction of nutrient pollution. ${ }^{428}$ Rapeseed is the most common feedstock for biodiesel; $38 \%$ of its production is dedicated to biofuels. ${ }^{429}$ Rapeseed has a high nutrient demand and winter rapeseed has one of the highest demands for nitrogen. ${ }^{430}$ Sunflower, another crop used for biodiesel, requires twice the amount of potassium and nitrogen as rapeseed. Sugar beet is the main crop for bioethanol and a good portion of its production is dedicated to biofuels (between 30 to $50 \%$ in France for example). It has a similar demand for nutrients as rapeseed, but requires significant use of pesticides and herbicides. ${ }^{431}$ Wheat and maize, also used for bioethanol, are other crops requiring heavy use of fertilizers, especially nitrogen, and pesticides. ${ }^{432}$ The heavy use of pesticides and fertilizers increases risk of water pollution, ranging from medium to high depending on the region and the type of crop. ${ }^{433}$ However, data on the specific water quality impact of biofuels production is still very limited. ${ }^{434}$ In general, only half of the EU rivers and lakes are in good ecological state, and $25 \%$ of groundwater has poor status, agricultural pollution being the major problem. ${ }^{435}$

In general, it was estimated that the environmental impacts from biofuels in Europe are higher or equivalent to fossil fuels due mainly to the impacts of the

\footnotetext{
${ }^{428}$ Diaz-Chavez et al, supra note 414 at 63; and EEA 2015, supra note 421 at 66-67.

${ }^{429}$ Diaz-Chavez et al, ibid at 19; and 2013 Progress Report SWD, supra note 393 at 18.

${ }^{430}$ Diaz-Chavez et al, ibid at 20 \& 68-69.

${ }^{431}$ Ibid at 24.

${ }^{432}$ Ibid at $20 \& 23$.

${ }^{433}$ High runoff risk in the Czech Republic, France, Germany, Hungary, Italy, Poland, Romania, Slovakia, Spain and the United Kingdom: ibid at 24-35.

${ }^{434}$ Ibid at 68 .

${ }^{435}$ EEA 2015, supra note 421 at 63-64.
} 
agroindustry. ${ }^{436}$ Furthermore, there is a clear risk that biofuels or feedstocks produced outside the EU will not respect the same environmental standards as internal biofuels or feedstocks, mainly due to the limits of the sustainability criteria. ${ }^{437}$ Overall, the environmental impacts of biofuels vary hugely depending on the type of feedstocks and even then, significant uncertainties remain, such as the effects of ILUC. ${ }^{438}$

\subsection{Beyond Environmental Concerns: Social Impacts}

Less explored than environmental impacts, but still crucial to the sustainability of biofuels production, are social impacts. The most well know impact is the issue of food security. ${ }^{439}$ While it seems that the impact of biofuels on global food prices was not as important as originally thought, it is still a crucial one since first generation biofuels compete with food for agricultural goods and even small price changes may have significant impacts on the world's poorest. Biofuels production also has important consequences on the labour markets. Finally, biofuels policies have benefited from advantageous state financial regimes (tax exemptions, subsidies, etc.), policies that impact the economic sustainability of biofuels production. This subsection summarizes data on these socioeconomic impacts.

\footnotetext{
${ }^{436}$ Charles et al, supra note 388 at 59.

437 Aziz Elbehri, Ana Segerstedt \& Pascal Liu, Biofuels and the sustainability challenge: A global assessment of sustainability issues, trends and policies for biofuels and related feedstocks (Rome: Food and Agriculture Organisation, 2013) at 99 [Elbehri et al]; and Diaz-Chavez et al, supra note 414 at 78-79.

${ }^{438}$ EEA 2013, supra note 397 at 33.

439 "Food security exists when, at all people, at all times, have physical and economic access to sufficient, safe and nutritious good that meets their dietary needs and food preferences for an active and healthy life": Food and Agriculture Organisation, World Food Summit, Rome, 1996, extracted from The Bioenergy and Food Security Project, Bioenergy and Food Security: The BEFS Analytical Framework, Environment and Natural Resources Management Series No 16 (Rome: Food and Agriculture Organisation, 2010) at 7 [BEFS].
} 


\subsubsection{Human Considerations: Labour and Food Security}

Biofuels impact food security by competing for resources - land, water, labour, investments etc. - with the agro-food industry. ${ }^{440}$ It is this competition for land, and for agro-products and resources, that increases the overall price of food. ${ }^{441}$ The Commission argues that the majority of biofuels produced for EU needs will have a limited impact on land rights since $70 \%$ of the biofuels consumed in the EU are produced locally, in the US or in Canada. ${ }^{442}$ While at first view this may seem to be correct since these developed nations tend to have good property rights protection, the Commission analysis does not appear to take into consideration the impacts or potential impacts of biofuels demand on indigenous peoples' rights and on small farmers' displacement. ${ }^{443}$ Moreover, it is more appropriate to qualify the link between EU biofuels demand and negative impacts on land rights (land grab deals, unfair compensation for taking of land, below market government land lease, etc.) as inconclusive and thus uncertain. ${ }^{444}$ After all, some feedstocks and biofuels do come from countries like Malaysia where a significant risk of land grabs and indigenous people displacement exists in the palm oil sector. ${ }^{445}$

As for food prices themselves, the consumption of bioethanol in the EU is estimated by the Commission to have increased the price of cereal on the global market

\footnotetext{
${ }^{440}$ BEFS, ibid at 9-11; and Elbehri et al, supra note 437 at 59.

${ }^{441}$ Kretschmer et al, supra note 406 at 14.

4422013 Progress Report SWD, supra note 393 at 22.

443 See Permanent Forum on Indigenous Issues, State of the World's Indigenous Peoples (New York: United Nations, 2009); and Perrine Burnod \& Jean-Philippe Colin, Large agricultural investments and inclusion of small farmers, Land Tenure Working Paper 23 (Rome: Food and Agriculture Organisation, 2012).

${ }^{444}$ ECOFYS et al, supra note 396 at 301; 2013 Progress Report SWD, supra note 393 at 22; and Elbehri et al, supra note 437 at 90 .

445 Tait et al, supra note 417 at 40-41; and Richard L Ottinger, "Biofuels - Potential, Problems \& Solutions" (2009) 19 Fordham Envtl L Rev 253 at 257-258.
} 
by 1 to $2 \%$ over the $2000-2010$ period. ${ }^{446}$ The impact of biodiesel over the same period is a $4 \%$ price increase for other food crops, including oils crops. ${ }^{447}$ The Commission estimates that prices for biofuels crops will have increased, using 2008 prices as the baseline, by a lowest of $0.74 \%$ for maize to a highest of $11 \%$ for rapeseed by $2020 .{ }^{448}$ It is of note that rapeseed is currently and is projected to be the most common feedstock in the EU. ${ }^{449}$ These increases do not factor in possible technological improvements. There are still uncertainties as to the extent of biofuels impacts on global food prices, but studies tend to demonstrate that policies aimed at promoting biofuels consumption add to the demand for oil and grain crops and consequently contribute to price increases. ${ }^{450}$ The results of these studies are imprecise as they establish a large range of estimated price increases for agricultural feedstocks due to biofuels during the period covered by the Renewable Energy Directive (the biggest range being for vegetable oil, 1 to $36 \%$, and the smallest for oilseeds, 8 to $20 \%) .{ }^{451}$ Nevertheless, it does not appear that biofuels production is the main cause of current food insecurity. ${ }^{452}$ While current food prices impacts remain small and uncertain, the impact of first generation biodiesel, the main biofuel used in EU, is far from negligible, especially when considering the food security of the poorest. ${ }^{453}$

\footnotetext{
${ }^{446} 2013$ Progress Report SWD, supra note 393 at 22-23.

${ }^{447}$ Ibid at 23.

${ }^{448} \mathrm{Ibid}$ at 23 .

${ }^{449}$ Kretschmer et al, supra note 406 at 50; and ECOFYS et al, supra note 396 at 202.

${ }^{450}$ ECOFYS et al, ibid at 396; and Charles et al, supra note 388 at 49-53.

${ }^{451}$ Charles et al, ibid at 50; and Kretschmer et al, supra note 406 at 48.

${ }^{452}$ ECOFYS et al, supra note 396 at 295; and Kretschmer et al, ibid at 41.

${ }^{453}$ See ECOFYS et al, ibid at 293-294; Kretschmer et al, ibid at 49; Charles et al, supra note 388 at 48 \& 53; FAO, The State of Good and Agriculture - Biofuels: prospects, risks and opportunities (Rome: Food and Agriculture Organization, 2008); and Alex Evans, The Feeding of the Nine Billion: Global Food Security for the $21^{\text {st }}$ Century (London: Chatham House, 2009).
} 
The Renewable Energy Directive uses the ILO conventions as a proxy for good labour practices. While most countries that export feedstocks or biofuels to the EU have ratified the ILO conventions identified in Article 17(7) of the Directive, enforcement and implementation in most developing countries remain weak. ${ }^{454}$ In fact, being parties to ILO conventions means little in terms of the health and well-being of a state's workforce. ${ }^{455}$ Furthermore, there are risks of forced labour in sugar cane production in Brazil and Guatemala, and in palm oil production in Malaysia, and risk of child labour in Indonesia for palm oil. ${ }^{456}$ Child labour due to biofuels crops is diminishing in both Brazil and Argentina due to the mechanization of harvesting. Discrimination based on ethnicity and gender remains prevalent in Indonesia. ${ }^{457}$ Moreover, the agroindustry is in general a sector with high workplace accidents, child labour and gender discrimination. ${ }^{458}$ Around $4.1 \%$ of biodiesel consumed in the EU originates from Indonesian and Malaysian palm oil, and $10.1 \%$ originates from Argentinian soybeans, while for bioethanol $8.4 \%$ originates from Brazilian sugar cane, making these risks far from inconsequential from an EU perspective. ${ }^{459}$

\footnotetext{
4542013 Progress Report SWD, supra note 393 at 25-26; ECOFYS et al, supra note 396 at 308; and International Labour Office, Report of the Committee of Experts on the Application of Conventions and Recommendations, Report III (Part 1A), International Labour Conference, 103rd Session (Geneva: International Labour Organisation, 2014) at Part II.

${ }^{455}$ Elbehri et al, supra note 437 at 93.

${ }^{456} 2013$ Progress Report SWD, supra note 393 at p 26; Tait et al, supra note 417 at 36-37; and Bureau of International Labor Affairs, List of Goods Produced by Child Labor or Forced Labor, US Department of Labor, September 2013.

${ }^{457}$ ECOFYS et al, supra note 396 at 309.

458 International Labour Office, Safety and Health in Agriculture (Geneva: International Labour Organisation, 2000); International Labour Office, Accelerating action against child labour, International Labour Conference, $99^{\text {th }}$ Session, Report I(B) (Geneva: International Labour Organisation, 2010); and Cheryl Doss, If Women Hold Up Half the Sky, How Much of The World's Food Do They Produce? (Rome: Food and Agriculture Organisation, 2011).

${ }^{459}$ ECOFYS et al, supra note 396 at 228-229.
} 
In the EU, labour rights are well protected compared to developing countries. ${ }^{460}$ Some issues remain however as there are still problems with labour rights, discrimination, and the social and economic integration of Roma, especially in Poland and other East-European member states. ${ }^{461}$ Additionally, a good portion of agricultural workers are migrant-workers who tend to suffer from lower socio-economic and occupational health and safety conditions. ${ }^{462}$

On a more positive side, biofuels production can be a good source of employment. The biofuels industry supported over 220000 jobs in the EU in $2010 .{ }^{463}$ It is estimated to support 730000 jobs in Brazil, and 114700 in Indonesia. ${ }^{464}$ Biofuels production is more labour intensive than its fossil fuels counterparts, although most employment opportunities tend to be concentrated in certain major economies such as Germany, the US and Brazil. ${ }^{465}$ The biofuels industry represents around half of renewable energy jobs. ${ }^{466}$ Employment is available for low (60\%), medium (10\%) and high (30\%)

\footnotetext{
${ }^{460}$ Isabelle Chopin \& Catharina Germaine-Sahl, Developing Anti-Discrimination Law in Europe, European Commission, Directorate-General for Justice, 2013; and Directorate-General for Employment, Social Affairs and Inclusion, Industrial Relations in Europe 2014, European Commission, 2015 at 147-159 [DG Employment].

${ }^{461}$ ECOFYS et al, supra note 396 at 309; DG Employment, ibid; Melanie H Ram, "Europeanized Hypocrisy: Roma Inclusion and Exclusion in Central and Eastern Europe" (2014) 13:3 Journal on Ethnopolitics and Minority Issues in Europe 15; and EU, Communication from the Commission on the social and economic integration of the Roma in Europe, Brussels, 7 April 2010, COM(2010) 133.

${ }^{462}$ Mans Svensson et al, Migrant Agricultural Workers and Their Socio-economic, Occupational and Health Conditions - A Literature Review, SSRN Working Papers series, 2013.

4632013 Progress Report SWD, supra note 393 at 26 . Charles et al note that the biofuels industry directly employs 121911 people. Another study claims that the biomass fuels industry in the EU supports 700000 jobs: Hugo Lucas et al, Renewable Energy Jobs: Status, Prospects \& Policies (Abu Dhabi: International Renewable Energy Agency, 2011) at 15.

${ }^{464}$ Lucas et al, ibid at 17.

${ }^{465}$ ECOFYS et al, supra note 396 at 304; and Lucas et al, ibid at 10.

${ }^{466}$ Lucas et al, ibid at 15.
} 
skill workers, and in part-time, full-time, contract, permanent and temporary positions, making employment opportunities from biofuels production very diverse. ${ }^{467}$

\subsubsection{It's the Economy Stupid: Taxes, Subsidies and Funding}

The economic impact of biofuels in the EU is significant and growing. The total wholesale biofuels market value in the EU was approximately $€ 15.2$ billion in 2011, which is about $25.5 \%$ of the global market (€59.6 billion). ${ }^{468}$ In economic turnover this number is around $€ 14.7$ billion compared to $€ 46$ billion for the solar sector and $€ 32$ billion for the wind sector (excluding heat/electricity sales), out of a total of $€ 137$ billion for the EU renewables sector. ${ }^{469}$

According to the International Energy Agency, the EU biofuels industry received in 2011 approximately $€ 8.4$ billion in subsidies, which is $46 \%$ of the global subsidies for biofuels (US\$24 billion), a large proportion considering EU consumption of biofuels amounts to $19 \%$ of world consumption. ${ }^{470}$ Charles et al calculate EU subsidies at between $€ 5.5$ and 6.9 billion, based on market transfers (e.g. mandatory blending of biofuel with fossil fuel), direct budgetary support for production/consumption, and research and development support. ${ }^{471}$ They note that the subsidy trend is moving upward and estimate it to reach $€ 6.9$ to 8.6 billion in $2015 .{ }^{472}$ Most of the research and development subsidies, around US\$ 2.5 billion for the 2007-2013 period, were geared towards second generation

\footnotetext{
${ }^{467}$ ECOFYS et al, supra note 396 at Annex X; Lucas et al, ibid at 11; and Charles et al, supra note 388 at 70.

${ }^{468}$ Charles et al, ibid at 18.

${ }^{469}$ Ibid at 20.

${ }^{470}$ Ibid at $18 \& 33$.

${ }^{471}$ Ibid at 20.

${ }^{472}$ Ibid at 40.
} 
biofuels projects as the technology is still at the early stage of commercialisation and in need of more research and development. ${ }^{473}$

Additionally, while the CAP does not directly support biofuels activities, it subsidises agricultural use of the land through the Single Payment Scheme, regardless of the end use of the cultivated produce. ${ }^{474}$ Feedstocks production accounts for approximately 60 to $90 \%$ of the production cost of biofuels. ${ }^{475}$ Based on 2008 data (data on this topic is scarce), the EU spent $€ 958$ million of CAP single payments that year on land producing biofuels feedstocks (the average rate was $€ 266$ per hectare). ${ }^{476}$ There is no certainty, however, that if the CAP didn't support biofuels feedstocks cultivation, the overall amount of money spent through the CAP would diminish since it is possible that farmers cultivating feedstocks would simply cultivate something else or the same produce for other ends. ${ }^{477}$

In regard to taxation, the Commission has expressed concerns over the inability of the Council to adopt a new directive for energy taxation. ${ }^{478}$ The impact of the absence of a progressive energy taxation framework that favours cleaner fuels is demonstrated by the decline of pure biodiesel in the market as the energy tax exemption of the product is phased out. ${ }^{479}$ Additionally, employment benefits of biofuels tend to be associated with adequate fiscal incentives. ${ }^{480} \mathrm{~A}$ decline in such incentives could negatively impact the EU labour market. Taxation of biofuels varies significantly between member states. In 2009,

473 Ibid at 35 \& 38; OECD \& IEA, supra note 397 at 37; and IRENA, Road Transport: The Cost of Renewable Solutions (Abu Dhabi: International Renewable Energy Agency, 2013) at 36 \& 47.

${ }^{474}$ Charles et al, ibid at 41.

${ }^{475}$ IRENA, supra note 473 at 24; and Charles et al, ibid at 31.

${ }^{476}$ Charles et al, ibid at 42.

${ }^{477}$ Ibid at 41.

4782013 Progress Report, supra note 405 at 9.

4792013 Progress Report SWD, supra note 393 at 12.

${ }^{480}$ ECOFYS et al, supra note 396 at 304-306. 
the tax exemption ranged between 0.00 and $0.68 €$ per litre of biodiesel, and 0.00 and $0.65 €$ per litre of bioethanol. ${ }^{481}$ As for the revenue derived from the taxation of the biofuels industry, it is currently impossible to estimate due to the lack of publicly available information on taxes paid by the industry. ${ }^{482}$ Finally, the imposition of some form of taxation based on GHG emissions could stimulate a greater investment interest towards renewable energy, especially clean fuels including low GHG emissions biofuels. $^{483}$

In summary, biofuels production in the EU has become a significant industry that will provide benefits through employment and revenues. The EU governments have poured large sums of money in the industry through direct subsidies and tax break and through agricultural subsidies. These measures, with the exception of research and development, appear to have little to do with the sustainability of biofuels, especially without the implementation of a carbon tax. Furthermore, the industry has a nonnegligible impact on food security and labour rights in developing nations. While the EU may have strong labour rights protection, it still relies on imports from developing nations with subpar performance in that field to meet demands for biofuels. These socioeconomic impacts coupled with the environmental ones raise serious doubts regarding the sustainability of the biofuels industry in the EU.

\footnotetext{
${ }^{481}$ David Jager et al, Financing Renewable Energy in the European Energy Market (Utrecht: ECOFYS, 2011) at 54-55.

${ }^{482}$ Charles et al, supra note 388 at 65-66.

${ }^{483} 2013$ Progress Report, supra note 405 at 9-10; and 2013 Progress Report SWD, supra note 393 at 6.
} 


\section{Sustainable in Practice? Assessing a Sample of EU Biofuels}

To complement the above summary of general studies on biofuels impacts, this section summarises four EU lifecycle assessment studies covering the three generations of biofuels. These lifecycle assessments will also serve to corroborate some of the general data gathered in the previous section, mainly the data on GHG emissions savings. The choice of lifecycle assessments was made in part to ensure methodological coherence, and in part due to the high relevance of the method for biofuels' GHG emissions. The first three studies produced results measured in GHG emissions savings according to the Renewable Energy Directive standards for ease of comparison, both to the Directive and between themselves. Since no study with those criteria was found for algae biofuels, the last study focuses on some specific algae-based biofuels production environmental impacts.

\subsection{The Agro-Energy Industry: First Generation Biofuels}

Biofuels made of agricultural feedstocks remain the most common biofuels available in the EU. They are also the most controversial and attempts made to limit their production are ongoing. First generation biofuels are created by refining high sugar crops into bioethanol or high fat crops into biodiesel. As shown above, the majority of issues related to first generation biofuels come from the agricultural process. Two lifecycle assessment studies are summarized in this sub-section, one regarding a specific biofuel, bioethanol made from Belgian wheat, and the other on the general GHG impact of EU first generation biofuels, including ILUC impacts. 
In the first study (hereafter the Belgian study), Sandra Belboom, Bernard Bodson and Angélique Léonard look at the environmental impacts, using lifecycle assessment, of Belgian bioethanol made from wheat and at its compliance with the Renewable Energy Directive. ${ }^{484}$ They also compare their results to the standard values given by the Directive to this type of biofuels. The Belgian study uses the functional unit of $1 \mathrm{MJ}$ of biofuel as recommended by the Directive (Annex V) and includes the four main stages of the bioethanol production: "(1) cultivation with production and application of fertilizers and pesticides, consumptions due to agricultural operations and use of land, (2) crops transportation from field to plant, (3) crops transformation into bioethanol, and finally (4) combustion. ${ }^{485}$ Belgian wheat is amongst the highest in terms of yields in the EU (8.6 tonnes per hectare, compared to the $3.6 \mathrm{EU}$ average), and therefore may represent a best case scenario.

The Belgian study takes into account average amount of fertilizers $\left(\mathrm{N}, \mathrm{K}_{2} \mathrm{O}\right.$ and $\mathrm{P}_{2} \mathrm{O}_{5}$, nitrates being the most used) and pesticides. It measures the average $\mathrm{CO}_{2}$ emissions from the use of fertilizers (but not $\mathrm{N}_{2} \mathrm{O}$ as no data was available), from diesel mechanical harvesters, from transportation trucks/tankers, and from transformation. It was assumed that no direct land-use change occurred, and ILUC were not taken into account. Since the transformation process of wheat bioethanol results in coproducts, the Belgian study divides the impacts between the bioethanol and the coproducts based on the energy value. The study also states the impacts of wheat bioethanol without taking into account the coproducts, in other words the impacts without division (for the worst case scenario).

\footnotetext{
${ }^{484}$ Sandra Belboom, Bernard Bodson \& Angélique Léonard, "Does the production of Belgian bioethanol fit with European requirements on GHG emissions? Case of wheat" (2015) 74 Biomass \& Bioenergy 58.

${ }^{485}$ Ibid at 59.
} 
The Belgian study's results attribute $68 \%$ of GHG impacts to the cultivation step, $27 \%$ to the transformation step, and 5\% to transportation. The use of Belgian wheat bioethanol barely reaches the applicable Renewable Energy Directive standard (35\%) with a 52\% GHG emissions savings when the impacts are divided. Without division, the bioethanol fails to meet the post 31 December 2017 standard (50\%) with $43 \%$ GHG emissions savings. ${ }^{486}$ The results differed, according to the study, in a non-negligible way from the Directive standard values (109\% of value, $91 \%$ with division). The terrestrial and freshwater eutrophication of wheat bioethanol is five times higher than that of gasoline. It also has three times the acidification rate and two times the particulate matter emissions of gasoline. The Belgian study concludes that Belgian wheat bioethanol has good GHG emissions savings potential when compared to gasoline, but that other environmental impacts will be the price to reach those savings.

In the second study (hereafter the EU study), Florian Humpenöder et al look at the GHG emissions saving potential of first generation biofuels produced in the EU using lifecycle assessment. ${ }^{487}$ To take into account direct and indirect land-use changes, the study separated the geography of the EU into grids and calculated the GHG emissions savings for each grid cell. The study follows the lifecycle methodology provided by the Renewable Energy Directive, and included GHG emissions from all stages of production.

It uses simulation to analyse potential land-use changes due to changes in crops and crop yields, considering the suitability of the land for a particular crop. The EU study covers all of the EU member states except Malta, Cyprus and Luxembourg, due to their size, and

\footnotetext{
${ }^{486}$ In a biorefinery built after 5 October 2015, the Belgian wheat bioethanol would not meet the Directive's standard of $60 \%$ in either scenario.

${ }^{487}$ Florian Humpenöder et al, "Effects of land-use change on the carbon balance of 1st generation biofuels: An analysis for the European Union combining spatial modeling and LCA" (2013) 56 Biomass \& Bioenergy 166.
} 
Croatia, who was not a member state at the time of the study. It compares first generation biofuels to a scenario without biofuels (the baseline scenario), and considers the demand for food. It considers two scenarios, one where first generation biofuels are 5\% of the transportation energy consumption, and one where they are $10 \%$. The scenarios are then considered twice, one with and the other without projected technology improvement (+9.4\% in crop yield, and $-10 \%$ in GHG emissions). The EU study looks at bioethanol from wheat, maize, sugar beet and rye/barley, and biodiesel from rapeseed, soybeans and sunflower oil, based on their 2010 feedstocks proportion.

The EU study found that no first generation biofuels under any scenario would reach the minimum GHG emissions savings of the Renewable Energy Directive. Without technology improvement the 5\% scenario results in 13\% GHG emissions savings, and the $10 \%$ scenario in a $1 \%$ GHG emissions savings. The situation is even worse with technology improvement as the first generation biofuels result in greater GHG emissions than fossil fuels: $-2 \%$ saving for the $5 \%$ scenario, and $-18 \%$ saving for the $10 \%$ scenario. The negative impact of technology improvement can be explained

... by taking into account the carbon stock changes in the baseline scenario. In the baseline with [technology improvement] less cropland is needed to fulfill the biomass demand due to higher increase in crop yields. The leftover cropland is converted to set-aside land. Ecological succession takes place and detracts carbon from the atmosphere. This results in negative GHG emissions in the baseline under [technology improvement] while GHG emissions are positive in the baseline under [no technology improvement]. In the biofuel scenarios overall GHG emissions increase. The GHG emissions attributable to 1st biofuel production are represented by the difference of the corresponding biofuel scenario and baseline scenario carbon stocks. Since GHG emissions in the baseline under [technology improvement] are negative, the impact of 1st gen. biofuel production on the GHG emission saving indicator is higher under 
[technology improvement] than [no technology improvement]. ${ }^{488}$ [table reference omitted]

Only Bulgaria, Germany, Greece, Latvia and the United Kingdom achieve at least 35\% GHG emissions savings, but only under the 5\% scenario, with or without technology improvement. The EU study concludes that first generation biofuels do not substantially reduce GHG emissions compared to fossil fuels.

\subsection{A House of Straw: Second Generation Biofuels}

While it is easy to convert the "food" part of plants into biofuels, it represents only a small portion of their biomass. Most biomass is found in the lignin and cellulose of cell walls. This can be extracted and used to form lignocellulosic biofuels. ${ }^{489}$ The best approach to make such biofuels is to use dual-purpose feedstocks, mainly residue from another activity such as forestry, sugar production, municipal waste, and agricultural operations. The goal is to use by-products that would otherwise have no use, and thus to have a very limited ecological footprint and to limit waste. ${ }^{490}$ The issues surrounding lignocellulosic biofuels are mainly the efficiency of harvesting material and transforming it into fuel, the temptation to grow lignocellulosic crops for biofuels purpose only (thus increasing agroindustry pollution), water availability (for the transformation process of some feedstocks), and the limited supply of by-products (e.g. many agricultural byproducts are used as natural fertilizers, thus using them for biofuels would potentially increase the use of chemical fertilizers). ${ }^{491}$

\footnotetext{
488 Ibid at 174.

${ }^{489}$ Tait et al, supra note 417 at 47.

${ }^{490}$ Webb \& Coates, supra note 420 at 16-17; and EEA 2013, supra note 397 at 44.

${ }^{491}$ Tait et al, supra note 417 at 48-49 \& 53; OECD \& IEA, supra note 397 at 67; and Webb \& Coates, ibid at 15 .
} 
Second generation and waste based biofuels only amounted to $1.4 \%$ of all biofuels consumed and $0.11 \%$ of the biofuels consumed for transportation. ${ }^{492}$ It is estimated that second generation biofuels will only account for $0.7 \%$ of energy use in transport by $2020 .{ }^{493}$ Interestingly, it is estimated that $10 \%$ of bio-residues can be used for second generation biofuels purposes, which would result in enough biofuels to meet the 2008 global demand for biofuels twice over. ${ }^{494}$

In a recent study, Johannes Lindorfer, Karin Fazeni and Horst Steinmüller look at GHG emissions of bioethanol made from cereal straw residue from Germany using the lifecycle assessment methodology. ${ }^{495}$ The study's functional unit is $1 \mathrm{MJ}$ energy content, and follows the EU standards set up in the Renewable Energy Directive. The study takes into account all steps of production, especially fuel consumption, and pesticides and fertilizers' manufacturing and use. It also takes into account GHG emissions from changes in the soil's carbon stocks due to land-use changes. The straw is obtained from existing agricultural operations, and thus the GHG emissions were allocated between the straw and the grain (based on mass, market value or heating value). The study makes no mention of ILUC.

Depending on the energy source used during production (the best results are achieved when the energy comes from the straw coproduct itself) and the allocation between straw and grain, the GHG emission savings potential of straw bioethanol ranges from 39 to $95 \%$. Following Annex V of the Renewable Energy Directive, which

\footnotetext{
${ }^{492}$ ECOFYS et al, supra note 396 at 201.

${ }^{493}$ Kretschmer et al, supra note 406 at 10.

${ }^{494}$ OECD \& IEA, supra note 397 at 57.

495 Johannes Lindorfer, Karin Fazeni \& Horst Steinmüller, "Life cycle analysis and soil organic carbon balance as methods for assessing the ecological sustainability of 2nd generation biofuel feedstock" (2014) 5 Sustainable Energy Technologies and Assessments 95.
} 
attributes $100 \%$ of emissions to the grain, the savings are of $95 \%$. Therefore straw bioethanol easily meets the most stringent GHG emissions savings requirement of the Directive $(60 \%)$. The savings are still promising under alternative allocation: allocation by market value results in $84 \%$ savings; allocation by mass results in $75 \%$ savings; and allocation based on heating value results in $68 \%$ savings. Additionally, the study notes that in order to maintain soil integrity, a portion of the straw must be left on the field, therefore limiting the availability of the feedstocks. This limit varies depending on the region (based on soil type, and other conditions).

\subsection{A little Help from Sun and Water: Third Generation Biofuels}

Finally, the last generation of biofuels available is algae-based biofuels. It is a promising but not yet widely used type of biofuel as the technology is still being developed. ${ }^{496}$ Algae-based biofuels can offer considerable advantages. ${ }^{497}$ Since algae are cultivated in water, the impact of direct and indirect land-use changes can be nil. Water is the only requirement and thus algae production can take place on low value or uncultivable land, even in places like desert, ocean platforms or rooftops. Algae are also more efficient than food crops as the entire product, not just one part like the seeds, is used to create either biodiesel or bioethanol. Algae can grow directly and solely on combustion gas, are much more uniform than other plants, do not require freshwater, and are not dependent on an annual growth cycle. While efficient algal production requires some fertilizers and thus could cause environmental harm, it is possible to use sustainable

\footnotetext{
496 Tait et al, supra note 417 at 57-59.

${ }^{497}$ Sjors van Iersel et al, Algae-based Biofuels: A Review of Challenges and Opportunities for Developing Countries (Rome: Food and Agriculture Organisation, 2009); Webb \& Coates, supra note 420 at 17; and Tait et al, ibid at 56.
} 
organic fertilizer or manure instead and reduce potential harm. ${ }^{498}$ Production also creates organic by-products that can either be treated through standard wastewater treatment (potentially more costly and could increase overall GHG emissions) or more efficiently be used as feed for cattle, fish or even humans.

The final study, conducted by Eva Sevigné Itoiz et al, concerns biodiesel made from three species of marine algae grown in the Mediterranean Sea. ${ }^{499}$ It uses a lifecycle assessment approach to measure the environmental impacts and energy balance of algae biofuels. Energy balance means the amount of energy required to produce biodiesel (energy input) compared to the energy produced by using the biodiesel (energy output). The study was conducted at a pilot plant in Barcelona. Some algae was grown indoors and some outdoors. The functional unit is one $\mathrm{kg}$ of dry algae biomass for each of the three species used. The environmental impacts measured were abiotic depletion, acidification, eutrophication, global warming potential, ozone layer depletion, human toxicity, freshwater ecotoxicity, marine ecotoxicity, terrestrial ecotoxicity, and photochemical oxidation. The lifecycle covered by the study includes growing the algae, the drying process (through centrifuging), and extraction of lipids to create the biodiesel. The sea water needed for the study was collected on site through pumps.

The outdoor system consumed significantly less energy than the indoor system in all species. The outdoor system also had lower environmental impacts. The indoor system resulted in $146.3 \mathrm{~kg}$ of $\mathrm{CO}_{2}$ eq per unit, while the outdoor system resulted in $23.24 \mathrm{~kg}$ of

\footnotetext{
${ }^{498}$ Algae could also be produced in the sea near human settlement to offset the increase of nutrient from fertilizer and wastewater runoff: van Iersel et al, ibid at 37-38

${ }^{499}$ Eva Sevigné Itoiz et al, "Energy balance and environmental impact analysis of marine microalgal biomass production for biodiesel generation in a photobioreactor pilot plant" (2012) 39 Biomass \& Bioenergy 324. The study does not produce results in term of $\%$ of GHGs emissions saving. I have attempted to find such a study to make comparison easier, but to no avail.
} 
$\mathrm{CO}_{2}$ eq per unit, a significant advantage. Most environmental impacts came from the energy needed during growth, based on Spain's energy mix which is $57 \%$ fossil fuels. Improvement in the Spanish energy mix would therefore improve the sustainability of algae biodiesel production in that country. The study notes that the energy balance of algae biodiesel can often be negative, meaning that the production of algae biodiesel required more energy than the biodiesel will produce upon combustion. A positive balance was only obtained under two scenarios. However, it noted that improvement in energy efficiency and technology design could significantly improve energy balance. The study concludes that outdoor production of marine algae produces superior and more sustainable results. Environmental impacts are limited and mainly due to energy consumption during production.

Marine algae biodiesel seem to provide some advantages over pond algae biofuels made with freshwater as it does not compete for freshwater and requires limited to no fertilizers. ${ }^{500}$ Further studies on the potential impact of mass production of algae biofuels are needed, especially to determine its GHG emissions savings potential. It is difficult to compare the algae study with the first and second generation studies presented in this section due to the unviability of certain data. We know that first generation biofuels do not appear to meet the GHG emissions savings standards of the Renewable Energy Directive, mainly due to ILUC. We also know that second generation biofuels show some promise. What we do not know yet is if third generation biofuels are a better option than second generation ones.

\footnotetext{
${ }^{500}$ See Laurent Lardon et al, "Life-Cycle Assessment of Biodiesel Production from Microalgae" (2009) 43:17 Environmental Science \& Technology 6475; and Harry Blass \& Carolien Kroeze, "Possible future effects of large-scale algae cultivation for biofuels on coastal eutrophication in Europe" (2014) 496 Science of the Total Environment 45.
} 


\section{Sustainable in Theory: Assessing the Essence of the Directive}

Because the impacts of biofuels vary so much between feedstocks, it is difficult to draw general conclusions on the sustainability of biofuels as a source of energy. However, this thesis is not evaluating the viability of biofuels as a replacement to fossil fuels. It assesses the sustainability of the Renewable Energy Directive's biofuels provisions, and this Directive creates certain standards that may sufficiently address the EU's sustainability concerns about biofuels. Now that the impacts have been described, they can be assessed as outlined in Subsection 4.2 of Chapter 2. This will be done in three steps. First, the form of the Renewable Energy Directive will be scrutinized in light of the integration principle. Do the Directive and its framework take into consideration (integrate) environmental and socio-economic impacts at all relevant levels of the lifecycle of biofuels production? Second, the Directive will be assessed in substance using the equity and polluters pay principles. Considering the three pillars of sustainable development and lifecycle assessment, will the likely impacts of EU biofuels production be addressed by the Directive in a manner compatible with intra and inter-generational equity? Third, the results of the assessment will be discussed and interpreted, ending this section and the chapter with an answer as to the sustainability of the Renewable Energy Directive's biofuels provisions.

\subsection{An Integrated Directive? Lifecycle and the Integration Principle}

The principle of integration is the starting point of the analysis. The meaningful integration of the three pillars - social, economic and environmental - by the Renewable Energy Directive is a crucial step in evaluating its sustainability. This part of the analysis 
will focus on legislative provisions, which are divided into the core provisions, that is the provisions of the Directive itself, and the supplemental provisions of other relevant legislation as outlined in Section 4 of Chapter 3. The core provisions are further divided into hard provisions, provisions imposing mandatory standards, and soft provisions, creating reporting, listing and other similar obligations. Hard provisions integrating the pillars are given more weight for the purpose of the assessment, due to their direct impact on the sustainability of biofuels. Hard provisions can be viewed as mandatory integration of certain factors, as the decision-makers' discretion is constricted by them, while soft provisions are only a way of providing information that can be considered by decisionmakers. As for the weight given to supplemental provisions, it depends on the integration/interaction of those provisions with the Directive and the broader EU policy on renewables and climate change. The language of the provisions is the primary consideration in this part of the assessment.

\subsubsection{Core Provisions: Integration in the Directive}

The hard provisions of the Directive are found mostly in Article 17, the sustainability criteria. The criteria are applicable to all biofuels consumed in the EU (hereafter the general criteria), with the exception of one which only applies to biofuels made with feedstocks cultivated in the EU (hereafter the EU criterion). The general criteria deal with two environmental concerns: climate change or GHG emissions savings, and biodiversity. Climate change concerns are clearly integrated into the scheme of the Directive; this is unsurprising given its place in the overall climate change policy of the EU. The minimum GHG emissions savings and the high carbon stock land criteria are the most obvious manifestation of this integration, but the criteria dealing with 
specific ecosystems like forests and peatlands are also part of this integration as these are known carbon stocks and their destruction could result in significant GHG emissions. ${ }^{501}$ In addition, the criteria dealing with the protection of these ecosystems and of highly biodiverse land represents the integration of biodiversity protection into the scheme. Biofuels made from waste and residues, other than agricultural, aquaculture, fisheries and forestry residues, are exempt from these criteria with the exception of the GHG emissions savings criterion. This is due to the fact that those types of biofuels are deemed to not have an impact on land and biodiversity as they are the product of recycled biomass. Since the exemption is based on environmental considerations, and aims at encouraging production of low impact waste based biofuels by simplifying standards, I consider the general criteria to represent a robust integration of environmental concerns.

However, these are not the sole environmental impacts of biofuels production. The EU criterion purports specifically to deal with part of those other impacts. It directly incorporates as a criterion the environmental requirements of the CAP direct support schemes, which are themselves mostly the incorporation of various EU environmental directives. In other words, it deals with agricultural pollution. While it is true that farmers would have to respect these environmental obligations through the implementation of environmental directives by the member states and through CAP direct support schemes (cross-compliance) ${ }^{502}$ it is possible to imagine some farmers being in violation of those laws and still wishing to sell their products as biofuels feedstocks. The Renewable Energy Directive attempts to avoid this scenario by making general environmental obligations

\footnotetext{
${ }^{501}$ See Preamble at Recitals 70-73 of the Renewable Energy Directive, supra note 387.

${ }^{502}$ Mitchel Cardwell, "European Union Agricultural Policy and Practice: The New Challenge of Climate Change" (2011) 13 Envtl L Rev 271 at 275.
} 
associated with agricultural production a mandatory standard for biofuels used for the purpose of the Directive. It shows a certain awareness on the part of the drafters of the need to ensure meaningful integration of environmental concerns in the Directive, including concerns already partially addressed by other legislation. ${ }^{503}$ Nonetheless, this criterion only applies to EU feedstocks. Feedstocks grown outside of the EU are exempt from its application. It is unclear why the Commission drafted the criterion as being applicable only to EU feedstocks. It may be that the Commission simply wanted to ensure internal legal consistency and ensure cross-compliance, or that the Commission was concerned that imposing EU environmental obligations to third party states would create international trade issues. From a sustainability point of view, however, such concerns are of lesser importance since if the goal is to ensure sustainable production of biofuels, such important agro-environmental standards should apply to all biofuels used to meet the requirements of the Directive. Even from an economic integration point of view this provision appears defective as it gives a trade advantage to foreign feedstocks over EU feedstocks, based on less stringent environmental standards. This failure to properly integrate environmental concerns for all biofuels regulated by the Directive is not saved by the soft provision mandating the Commission to monitor third countries' environment and to list countries that have ratified and signed certain multilateral environmental agreements. Nevertheless, the Directive does provide for a variety of environmental monitoring and reporting obligations, even for third countries. It is worth mentioning the reporting on ILUC which triggered the 2015 amendments to the Directive.

${ }^{503}$ Cardwell, ibid at 286-287. 
The Directive has also integrated economic concerns. The mandatory target of $10 \%$ of renewables in the road transportation sector acts as an economic incentive to promote the use and the production of biofuels, which will undoubtedly benefit the EU biofuels industry. The commission is also required to monitor and report on the cost of different biofuels. Additionally, the sustainability criteria are also reflective of trade concerns. They were adopted under the harmonization provision (Article 114) of the TFEU to ensure internal market consistency. ${ }^{504}$ The harmonization provision prevents member states from adopting other or more stringent criteria that could hinder biofuels trade. The criteria are a good example of economic and environmental integration. The criteria are primarily environmental standards but in drafting the legislation, the Commission took into consideration the effect such standards can have on the EU economy, and also on the viability of the scheme, as one could say that if standards vary between member states, the usefulness of an EU scheme would be diminished by the creation of different smaller biofuels markets within the EU. Moreover, the criteria are used to determined eligibility for financial support, thus increasing the scheme's coherence and ensuring that the economic development of the industry does not take precedence over environmental concerns. The last environmental and economic consideration integrated in the Directive pertains to advanced biofuels. To encourage their development, production and use, the Directive creates a second sub-target for advanced biofuels of $0.5 \%$ of final energy consumption in road transportation and makes Annex IX advanced biofuels count for twice their energy value for the purpose of meeting the $10 \%$ target.

\footnotetext{
${ }^{504}$ Seita Romppanen, "Regulating Better Biofuels for the European Union" (2012) 21 Eur Energy \& Envtl L Rev 123 at 127.
} 
The Renewable Energy Directive does not fare as well with the integration of the social justice pillar. In fact the only social integration of the Directive is found in soft provisions. The Commission has to monitor and report the impact of biofuels on food prices and on land-use rights. The Commission must also list countries that ratified and implemented core ILO Conventions. There was some support for the inclusion of social criteria in the Directive, but no action on this issue was ultimately taken considering the potential vulnerability of those criteria to international trade challenges. ${ }^{505}$ While the impact of soft provisions should not be underestimated (e.g. the reporting obligations on ILUC did result in amendments to the Directive to address the ILUC issue), they do not have the same legal force as a hard provision since their concrete effects depend on the goodwill of the EU institutions or the member states. Information made available through monitoring and reporting can be very useful, but information alone will not limit the social impacts of biofuels production. The Directive does include some limited social integration, but it is considerably weaker than its economic and environmental integration.

\subsubsection{Supplemental Provisions: Integration through the Framework}

Integration can also be considered through the supplemental provisions. Many EU laws impact the sustainability of biofuels and cross-compliance will definitely affect EU biofuels production. While I will focus mostly on environmental and to some extent economic integration, I note that EU cross-compliance integration also deal with a variety of social justice issues through EU laws on labour and employment standards, human

\footnotetext{
${ }^{505}$ Cardwell, supra note 502 at 287.
} 
rights, health and safety standards, etc., and through international agreements, most notably the European Convention on Human Rights. ${ }^{506}$

Economic integration in the supplemental provisions takes mostly the form of taxes and customs measures, and to a certain extent carbon pricing. The customs duties applicable to biofuels vary depending on the feedstocks. The variation is not linked to environmental concerns and reflects a mix of economic protectionism and competitiveness concerns through antidumping and countervailing duties. The customs duties obviously give an advantage to the EU biofuels industry over imported goods which can indirectly results in increased environmental protection due to the more stringent sustainability criterion only applicable to EU feedstocks. However, I cannot count this involuntary side effect as willful integration of environmental protection. Additionally, the customs duties for biofuels originating from developing countries are reduced or nullified as a development measure, which can be seen as integrating social justice concerns. Reduction of duties for developing countries is also based partially on sustainability concerns, further integrating the environment pillar.

On the taxation side, the Energy Taxation Directive provides for certain tax break measures for bioenergy. These measures exist to stimulate the biofuels industry by making its products more competitive with traditional fuels. These measures integrate partially environmental concerns by being more favorable to pure biofuels than to blended biofuels. It is hard to construe such measure as being environmental or not since the taxation rate or the measures are not based on environmental data (e.g. GHG

\footnotetext{
${ }^{506}$ Convention for the Protection of Human Rights and Fundamental Freedoms, 4 November 1950, 213 UNTS 221. See also supra note 460.
} 
emissions or types of agricultural practice). Generally speaking, the integration of the economic pillar in the supplemental provisions is mostly done through creating favorable conditions for the EU biofuels industry.

A considerable integration of economic and environmental issues is found in the EU ETS. The cap-and-trade regime ensures the progressive reduction of GHG emissions and puts a price on a form of pollution, internalizing environmental costs. However, since the ETS does not apply to road transport and agriculture, the regime has little impact on biofuels production. The only covered sector that may benefit from biofuels' GHG emissions savings potential is aviation, and in that case the sustainability criteria are integrated in the ETS scheme to ensure the GHG emissions savings potential of biofuels usage. Since the ETS is of limited applicability, its integration of the economy and environment pillars through carbon pricing is only partial and relatively weak.

The Fuel Quality Directive directly implicates the use of biofuels through its fuel decarbonisation requirements. The Fuel Quality Directive and Renewable Energy Directive are fully integrated as they share the exact same sustainability criteria regime to ensure coherence and ease cross-compliance. The Fuel Quality Directive thus follows the integration principle the same way the Renewable Energy Directive does.

The supplemental provisions that may have the greatest impact on the biofuels regime are, however, those of the Energy Efficiency Directive. Its provisions, aimed at promoting energy efficiency, can reduce the total amount of energy required to meet the Renewable Energy Directive mandatory targets. Energy efficiency is reflective of the three pillars: it reduces energy costs, including for the poorest, who are the most 
susceptible to energy price fluctuations; reduces energy consumption, and thus pollution associated with it; and stimulates a green economy through energy efficiency innovations, products and services. This integration is, nonetheless, only remotely associated with biofuels since the impact of the Energy Efficiency Directive is to potentially limit the use of biofuels. Yet the three climate change mitigation directives mention above are all part, with the Renewable Energy Directive, of the broader EU regime to combat climate change, and should thus be considered together to the extent possible.

Finally, the integration of environmental protection is also accomplished through EU environmental law, especially concerning the protection of biodiversity and the mitigation of agricultural pollution, mainly water pollution. A significant portion of these provisions are part of the sustainability criterion applicable to EU feedstocks. Those not directly incorporated are still legal obligations, mostly hard provisions, requiring compliance. They will thus affect the environmental sustainability of biofuels, especially the first generation. The integration of the general environmental regime with the biofuels one is further accomplished through the definition of highly biodiverse lands which include habitats designated under the Habitats Directive and the Birds Directive.

In summary, the Renewable Energy Directive does a fair job at meaningfully integrating environmental protection into its regime. The whole of legal obligations applicable to biofuels production take into consideration the main environmental impacts of biofuels; that is GHG emissions savings, loss of biodiversity, and agricultural pollution. This is less true of biofuels made with foreign feedstocks since they depend on weaker foreign environmental legislation (according to ECOFYS analyses). The 
Directive also fares well with economic integration by creating favorable conditions for the production of EU biofuels. There is still, however, a lack of efficient carbon pricing applicable to biofuels. To use a French expression, "la où le bât blesse" (where the weak point lies) is the social integration of the Directive. While biofuels production can benefit from the labour and human rights protection in place in the EU, imported biofuels or feedstocks are not covered by any hard EU social obligations. Additionally, no concrete step exists to ensure minimal impact on food security. The Directive is thus only a partial reflection of the principle of integration. Additionally, an important caveat is the fact that the sustainability criteria do not apply to biofuels at large, but only to biofuels used to meet the targets of the Directive and/or receiving subsidies.

\subsection{Analysing Equity: The Mitigation of Biofuels Impacts by the Directive}

The principle of integration highlighted the EU biofuels legal framework's capacity to take into account the three pillars of sustainable development. What was not covered was how effective those considerations are in limiting the negative effects of biofuels production. Taking into account what was exposed above and the lifecycle assessment approach, this subsection looks at the substance of the Renewable Energy Directive and relevant legislation to determine the sustainability of the regime by relying on the more substantive principles of equity, and when applicable on the polluter-pays principle. Are the legislative provisions adequate to avoid irreparable environmental harm and ensure the conservation of natural resources for use by future generations? Do they achieve or attempt to achieve this without compromising the present generation's right to the equitable enjoyment of resources and the fruits of development? Is the 
economic burden of development shouldered by the polluters or the public at large? The available data may not always provide a clear answer to those questions. Drawing upon the precautionary principle and keeping in mind that scientific uncertainties should not limit environmental protection, a risk of negative impacts demonstrated by or reasonably inferred from the data will be considered, for the purpose of this assessment, as a potential negative impact to the environment or to society. This is to avoid equating scientific uncertainties with absence of risks or with reduced potential negative impacts.

\subsubsection{Inter-generational Equity and the EU Biofuels Industry}

One can argue that if the GHG emissions saving potential of biofuels ends up being a myth, the validity of the Renewable Energy Directive's mandatory target scheme falls apart. Climate change mitigation is after all one of the purposes of the Directive and climate change is arguably one of the most important environmental considerations for inter-generational equity. On paper, the Directive seems to address this issue adequately through its sustainability criteria, mainly the minimum GHG emissions savings criterion. There is, however, one major issue with the criteria: the methodology used, while based on lifecycle assessment, does not take into account ILUC. The Commission and the Parliament have recognized the importance of this problem by trying to amend the Directive. It is evident that the vast majority of biofuels used to fulfil the requirements of the Directive are from the first generation. It appears that this trend is unlikely to change when the deadline of 2020 will arrive. Since first generation biofuels are associated with important ILUC impacts, it appears prima facie that the Directive's goal will not be achieved under the current criteria. 
The problem becomes apparent when looking at the data. The Commission estimates seem worthwhile. The Belgian study, which uses the exact same methodology as the Directive, confirms those estimates. It is when we start approximating the impact of ILUC on the GHG emissions savings averages found in the Directive and in the Commission's estimates that we see the inadequacy of the current criteria. The EU study shows that when ILUC impacts are taken into account, the numbers obtained by the Commission look dubious. At best, the EU study estimates a 1\% GHG emissions saving, and at worst a $-18 \%$ saving, indicating that biofuels can be worse than fossil fuels in terms of GHG emissions. Even if capped at 5\% of total transport energy, first generation biofuels still fail to meet the GHG emissions savings standards under a best case scenario. The data of Charles et al, exploring different scenarios, confirms this. Furthermore, even with the current $7 \%$ cap of the ILUC Directive, the minimum GHG emissions savings standards of the Directive will not be met in actuality. Only second and third generation biofuels seem to have the capacity to mitigate climate change in any meaningful way. Sadly, the conditions for their mass production and consumption are simply not there yet, even with the increased value of advanced biofuels for the purpose of meeting the Directive's target. ${ }^{507}$

Since the part of the ETS dealing with aviation and the Fuel Quality Directive share the same sustainability criteria for biofuels as the Renewable Energy Directive, those measures also share the same concerns. Only the Energy Efficiency Directive may have a positive impact by reducing the total amount of first generation biofuels needed to meet the $10 \%$ target, but it cannot completely negate the impact of biofuels that will be

\footnotetext{
${ }^{507}$ See Romppanen, supra note 504 at 129.
} 
used. ${ }^{508}$ There is thus a high risk that the Renewable Energy Directive, even with the help of other legislation, will not have a positive impact on climate change mitigation, and may even have a negative one.

In addition to the climate change concern, first generation biofuels production can have adverse impacts on the environment through loss of biodiversity. The member states, through their reporting obligations, state that the impact of biofuels production on biodiversity will be minimal. This is partially confirmed by a commissioned assessment which found the risks low for most of the EU, except in Spain and Poland which have moderate risks. The risks are more pronounced with regard to grassland ecosystems - the loss of grassland has been characterized as dramatic. ${ }^{509}$ The general state of biodiversity in Europe is, however, not looking good. In addition to wide spread issues regarding the implementation of the Habitats and Birds Directives, the 5-10 years and the 20+ years trends for biodiversity indicate that $60 \%$ of protected species and $70 \%$ of protected habitats are in unfavourable conditions. ${ }^{510}$ These trends are in part due to the pressure of

\footnotetext{
${ }^{508}$ Although energy efficiency does have a significant GHG emissions reduction capacity. Therefore, theoretically, the GHG emissions savings done via efficiency (and also through other ways) could nullify the GHG emissions of biofuels production: EEA, "European briefings - Energy" in The European environment - state and outlook 2015, online: www.eea.europa.eu < http://www.eea.europa.eu/soer2015/europe/energy >; and EEA, "European briefings - Mitigating climate change" in The European environment - state and outlook 2015, online: www.eea.europa.eu < http://www.eea.europa.eu/soer2015/europe/mitigating-climate-change $>$.

${ }^{509}$ EEA, "European Briefings - Agriculture" in The European environment - state and outlook 2015, online: www.eea.europa.eu < http://www.eea.europa.eu/soer-2015/europe/agriculture > [EEA Agriculture].

${ }^{510}$ EEA 2015, supra note 421 at 56-62; EEA Agriculture, ibid; EEA, "European Briefings - Biodiversity" in The European environment - state and outlook 2015, online: www.eea.europa.eu < http://www.eea.europa.eu/soer-2015/europe/biodiversity > [EEA Biodiversity]; Nicolas de Sadeleer, "EC Law and Biodiversity" in Richard Macrory, ed, Reflections on 30 Years of EU Environmental Law - A High Level of Protection? (Groningen: Europa Law Publishing, 2006) at 364 \& 368-369; Peter G G Davies, European Union Environmental Law: An Introduction to Key Selected Issues (Burlington: Ashgate Publishing, 2004) at 139-140; Commission v Spain, C-355/90, [1993] ECR I-4221; Commission v Netherlands, C-3/96, [1998] ECR I-3031; Commission v France, C-220/99, [2001] ECR I-5831; Commission v Ireland, C-67/99, [2001] ECR I-5757; Commission v France, C-202/01, [2002] ECR I11019; and Commission v France, C-96/98, [1999] ECR I-8531.
} 
agriculture to which biofuels production contributes. ${ }^{511}$ The risks due to low legal protection are significant for countries that export feedstocks or biofuels to the EU, with many countries having high risks, including major exporter Argentina, and medium risks for most of the other exporters. Many exporter states are noticing troubling trends on loss of sensitive ecosystems such as peatland, wetland, and tropical forests, many of which are habitats for endangered species. ${ }^{512}$ While EU legislation may have some positive effects on biodiversity, ${ }^{513}$ it seems that, considering the current circumstances, regulated biofuels production will still cause adverse impacts to biodiversity.

First generation biofuels also tend to have negative impacts on water quality due to the use of fertilizers, pesticides and herbicides. Many of the main exporter states where regulations are less robust than in the EU - have high risks for water quality. ${ }^{514}$ Poland has a similarly high risk while other large member states have a moderate one. The most common feedstocks for biodiesel and bioethanol in the EU require considerable amounts of fertilizers and pesticides. Nevertheless, water quality is improving within the EU, especially with nitrates pollution since contaminant levels have stabilized due to the Nitrates Directive. ${ }^{515}$ There is still, with intensive agricultural production, a risk of nitrogen pollution that will result in continued eutrophication of water bodies, and of pesticides pollution as pesticides continue to be widely detected in surface water and

\footnotetext{
${ }^{511}$ EEA Biodiversity, ibid.

512 See generally Convention on Biological Diversity, Global Biodiversity Outlook 3 (Montréal: Secretariat of the Convention on Biological Diversity, 2010).

513 See for example Fiona J Sanderson et al, "Assessing the performance of EU nature legislation in protecting target bird species in an era of climate change" [2015] Conservation Letters.

${ }^{514}$ Diaz-Chavez et al, supra note 414 at $77-78$.

515 EEA 2015, supra note 421 at 67; EEA Agriculture, supra note 509; and EEA, "European briefings Freshwater quality" in The European environment - state and outlook 2015, online: www.eea.europa.eu < http://www.eea.europa.eu/soer-2015/europe/freshwater > [EEA Freshwater].
} 
groundwater ${ }^{516}$ While many bodies of freshwater are not in a good ecological state (57\% of surface water in 2009), the continuous implementation of the Water Framework Directive has improved the situation and continuous progress is expected although at a lesser rate than prescribed by the Directive. ${ }^{517}$ Agriculture remains one of the main sources of water pollution. ${ }^{518}$ The situation is thus uncertain as there are some signs that the EU is heading in the right direction in terms of water quality, but the increase in agricultural activities through the Renewable Energy Directive's 10\% target in transport may slow, halt or even negate progress. I will therefore err on the side of caution and assert that without evidence that the EU will increase water protection to counteract the effect of biofuels production, the water quality impact of biofuels production will negatively affect inter-generational equity.

\subsubsection{Intra-generational Equity, Polluter Pays, and Biofuels' Socio-economic Impacts}

One of the main social concerns associated with biofuels is food security. This concern is geared mainly towards developing countries which often feel the effects of food prices fluctuation more intensely than the member states of the EU. With an impact of only a 1 to $2 \%$ price increase for cereal and $4 \%$ for oil crops over the 2000-2010 period, biofuels may seem like less of a threat to food security than originally thought. However, when divided by crops, the increase can be as high as $36 \%$ (vegetable oil). The impact is at least lowest for cereal crops, which often form the basis of many diets. In my

\footnotetext{
${ }^{516}$ EEA 2015, ibid at p 66-68; EEA, "European briefings - Hydrological systems and sustainable water management" in The European environment - state and outlook 2015, online: www.eea.europa.eu < http://www.eea.europa.eu/soer-2015/europe/hydrological-systems > [EEA Hydrology]; and EEA Freshwater, ibid.

${ }^{517}$ EEA 2015, ibid at 62-68; and EEA Freshwater, ibid.

${ }^{518}$ EEA 2015, ibid at 64; EEA Hydrology, supra note 516; and EEA Freshwater, ibid.
} 
opinion, uncertainty is the greatest threat here. ${ }^{519}$ The numbers offered by different studies differ greatly, and even in a single study the precise impact of biofuels on food security is uncertain. When you add to these issues the increased pressure on land created by biofuels demands that can result in land grabs and population displacement, especially in developing countries and in countries with indigenous populations, and the low labour standards of most exporter states, it seems that the EU biofuels production could contribute in a non-negligible way to social inequities. ${ }^{520}$

On the other hand, biofuels production does seem to contribute to the development of some developing states, like Brazil and Indonesia. It is unclear to what extent EU policy has influenced that development. I do not believe that the employment and capital the EU biofuels industry generates can justify potential social inequalities considering uncertainties, the fact that most of the employment is not situated in the poorest rural areas, ${ }^{521}$ and how little the EU has done to integrate those concerns in the Renewable Energy Directive and to counteract the known social effects of biofuels production outside of the EU. Furthermore, the negative social impacts seem to affect mainly marginalised populations in developing states, while the benefits (including alleged ones) are concentrated in developed states like EU member states and the US.

The final consideration of this analysis is the polluter pays principle. The main issue is thus environmental cost internalization. The question is not negligible since the

\footnotetext{
${ }^{519}$ Charles et al, supra note 388 at 99-100.

${ }^{520}$ Klaus Deininger et al, Rising Global Interest in Farmland: Can it Yield Sustainable and Equitable Benefits? (Washington: World Bank, 2011); and UN Special Rapporteur on the right to food, Note on the Impacts of the EU Biofuels Policy on the Right to Food, United Nations, Office of the High Commissioner for Human Rights, 23 April 2013, online: www.srfood.org < http://www.srfood.org/fr/special-rapporteururges-phase-out-of-eu-biofuel-incentives >.

${ }^{521}$ Charles et al, supra note 388 at 100.
} 
EU biofuels industry is heavily subsidised; it receives nearly half of the total global biofuels subsidies. The industry has also benefited from favorable tax regulations. Sadly, there is little data available on subsidies and taxation. ${ }^{522}$ The CAP direct support schemes link compliance with EU environmental obligations to farmers' support payments. While this system may not charge farmers the cost of their pollution, it at least does not directly subsidise pollution. The same can be said for biofuels subsidies which are tied to compliance with the sustainability criteria. Unfortunately, the ETS does not apply to agricultural production and without the implementation of an EU wide carbon tax, first generation biofuels production does not integrate the cost of its GHG emissions. Even the application of the ETS to the aviation sector is of no help as biofuels used for that purpose are considered carbon neutral if they respect the sustainability criteria even though most of them are clearly not.

While the financing regime has some environmental basis, the above intergenerational equity assessment shows that current standards may not be as reflective of good environmental performance as one may have thought, especially the sustainability criteria. The regime appears to be more geared towards giving an economic advantage to the EU biofuels industry to ensure its success and its competitiveness. It certainly does not seem to internalise environmental costs and is certainly not based on GHG emissions savings ${ }^{523}$ Only funds for research and development, geared mainly towards the more sustainable advanced biofuels, can be said to be linked mainly to environmental interests. Therefore, considering the significant environmental impacts of biofuels production, the

\footnotetext{
${ }^{522}$ Ibid at 98-99 \& 101.

${ }^{523}$ Ibid at $98-102$.
} 
overall funding regime of the EU biofuels industry is not in line with the polluter pays principle.

\subsection{Interpreting the Results: Synthesizing the Principled Lifecycle Assessment}

The road to hell is paved with good intentions, the saying goes. The EU might have had high hopes that the Renewable Energy Directive would provide a viable framework for the sustainable development of biofuels, but sadly the Directive may in the end cause more damages than it purports to remedy. The EU's good intentions are clearly stated in the Directive but they are also visible in the integration of environmental and economic concerns in its framework. It shows some understanding of potentially negative impacts of biofuels on the environment. Social integration in the Directive was very limited - although it is possible to argue the Commission had good reasons not to create social criteria - but even this weak integration of social concerns shows at least that the EU was aware of social issues. Regardless of all the EU's efforts, the data on the impacts of EU biofuels production points in the unsustainable direction. The absence of true GHG emissions savings together with the cumulative impacts on water quality and biodiversity indicate that even with current legal protection the EU biofuels industry will have an adverse impact on the environment and thus diminish inter-generational equity. The extremely limited measures to ensure the respect for minimal labour rights and standards abroad, and to limit food insecurity, mean that the industry is also likely to negatively impact intra-generational equity. Moreover, the fiscal measures tied to biofuels production do not follow the polluter pays principle by creating generous fiscal regime for the industry based only minimally on environmental concerns and with little regard to 
the internalization of environmental costs. The Renewable Energy Directive will therefore not result in the sustainable development of biofuels.

Why then is the Directive not achieving its sustainable development goal? Why is the Commission failing to achieve sustainability in the biofuels sector even though it started regulating biofuels since at least 2003 and has been involved in the sector since 1992? I see two potential and intertwined reasons. Firstly the Commission has systematically disregarded or inappropriately measured risks associated with biofuels. The 2003 Renewable Energy Directive contained no sustainability provision and mainly created a target for biofuels use. Environmental issues associated with production of biofuels were not unknown at that time and the Commission cannot plead ignorance. ${ }^{524}$ Since the 2003 target was not going to be reached and since member states and stakeholders started raising biofuels sustainability concerns, the Commission proceeded with the creation of the current Renewable Energy Directive in an attempt to deal with some of the sustainability issues. Even though, as we can see through the Directive's provisions themselves, the Commission was well aware that considerable uncertainties existed on issues such as ILUC and food security, it chose to adopt a mandatory target for road transport that it knew would mainly be met through biofuels, mostly of the first generation. ${ }^{525}$ The precautionary principle mandates that scientific uncertainties should not limit environmental protection measures. Thus, adopting the sustainability criteria, even if we know they are not as effective as hoped, was a good move. What the

\footnotetext{
${ }^{524}$ See for example EC, Communication from the Commission to the European Parliament, the Council, the Economic and Social Committee and the Committee of the Regions on alternative fuels for road transportation and on a set of measures to promote the use of biofuels, 7 November 2001, COM(2001) 547.

${ }^{525}$ See also UN Special Rapporteur on the Right to Food, Report of the Special Rapporteur on the right to food, GA, $62^{\text {nd }}$ Sess, UN Doc A/62/289, (2007).
} 
Commission should have done differently is to adopt those criteria for all biofuels consumed in the EU, and postponed the consideration for adopting a mandatory target in the transport sector to a day when the Commission would have better information on ILUC and food security. Instead it moved too fast, decided to deal with uncertainties later, and created a situation that is now hard to change as shown by the difficulties with the adoption of the 2015 amendments. ${ }^{526}$

Secondly, the Commission has put itself in a difficult political situation. The EU political structure means that compromise is often needed in order to pass legislation. Such compromises are easier to reach in a blank state situation; but we are no longer in such a situation in part due to the past actions of the Commission. Many member states now have a stake in the biofuels industry (including France, Poland and Spain, who have a considerable weight in the Council), and are pushing their view through Council, which has significantly diminished the potency of the original ILUC Proposal. ${ }^{527}$ The Commission's lack of foresight has created a situation where, even though the Commission now realises the importance of dealing with ILUC, it cannot deal effectively with the problem considering the obstruction of the Council. Even with the ILUC Directive, the EU will only limit the extent of the damages caused through the mandatory target.

\footnotetext{
${ }^{526}$ See EU, European Parliament, Legislative Observatory, Fuels and energy from renewable sources: transition to biofuels to deliver greenhouse gas savings, 2012/0288(COD), online: www.europarl.europa.eu $\langle$ http://www.europarl.europa.eu/oeil/popups/ficheprocedure.do?lang=en\&reference=2012/0288(COD) $>$.

${ }^{527}$ See EU, General Secretariat of the Council, Statements on Proposal for a Directive of the European Parliament and of the Council amending Directive 98/70/EC relating to the quality of petrol and diesel fuels and amending Directive 2009/28/EC on the promotion of the use of energy from renewable sources (first reading), Brussels, 1 December 2014, 15884/14 ADD 1 REV 1.
} 


\section{Conclusion}

The Renewable Energy Directive was created to promote, in part, renewables in transport. The EU saw fit to include a mandatory target to stimulate the industry and ensure results. This target was, however, premised on the sustainability of biofuels production. One of the big questions was how much GHG emissions can be reduced if fossil fuels are replaced by biofuels. The Commission estimates seemed promising, but they have a fatal flaw: they do not consider ILUC. The numbers were recalculated by others to estimate the impact of ILUC. The results were far grimmer, as no first generation biofuel was even close to meeting the GHG emissions savings criterion of the Directive. Only second and third generation biofuels show some promise, but they are not yet available on a commercial basis. To make matters worse, first generation biofuels have a significant impact, due to the cultivation of feedstocks, on water quality and biodiversity, both in the EU and abroad. They do not fare better on the social side of things as the increased biofuels production is associated with some rise in food prices. Weak labour standards in exporter states also contribute to the negative impacts of first generation biofuels, a heavily subsidised industry.

It seems that even though the Commission took care to integrate in the Directive and through other relevant legislation the three pillars of sustainable development though more the environmental and economic ones than the social one - the Directive is failing to create a sustainable biofuels industry in the EU. The sustainability criteria may consider GHG emissions, biodiversity and for EU feedstocks cross-compliance with other environmental obligations, and the relevant legislation may attempt to cover many aspects of biofuels environmental and socio-economic impacts, but it is simply not 
enough, especially considering ILUC and uncertainties. The Directive, because of its mandatory target, will therefore probably result in adverse environmental impacts and an increase in social inequities. Its financing regime fares no better as it continues to generously fund an industry that clearly will contribute to EU and global pollution and climate change. The Renewable Energy Directive does not follow the principles of equity and polluter-pays, and in general, following a principled lifecycle assessment approach, it is not a sustainable solution to fossil fuels usage. 


\section{Chapter 5 - When Good Intentions Are Not Enough: $\underline{\text { Recommendations and Conclusion }}$}

\section{Reflections on the Sustainability of Biofuels Production: Some Recommendations}

The current biofuels industry in the EU relies heavily on agricultural feedstocks. Since the agroindustry is far from being pollution free, it is no surprise that if a government wanted to promote biofuels as a clean renewable source of energy, it had to find a way to deal with the environmental impacts, especially GHG emissions, of biofuels production. Otherwise why exchange fossil fuels with biofuels? The EU chose to promote biofuels through the Renewable Energy Directive. The Directive's sustainability criteria were supposed to be the guarantee of biofuels' viability as a "green" alternative to fossil fuels. Good intentions are unfortunately not enough and the complexity of first generation biofuels quickly became apparent. With ILUC in the picture, studies are showing that first generation biofuels are no better and can be even worse than fossil fuels. Additionally, EU biofuels production will likely negatively impact water quality, biodiversity, and food security. A principled lifecycle assessment of the Directive and its framework has shown that the EU regulation of biofuels is not sustainable. With this information in hand, what options lay ahead for biofuels in the EU? To end this thesis I thus propose to address two final points: the utility of biofuels for the future; and recommendations for EU decisions-makers on what to do with the Renewable Energy Directive. 


\subsection{Climate Change Mitigation: Are Biofuels a Realistic Option?}

The question posed, are biofuels a realistic option, is a legitimate one considering the data exposed by this thesis. One might be tempted to simply give up on them and move on to potential new solutions to our dependence on fossil fuels. This would be a short sighted move. It has become relatively clear that first generation biofuels are not sustainable. Their environmental, social and even economic prices are simply too high. Their GHG emissions seem no better than fossil fuels due to ILUC. By adding to the demand for arable lands, they increase agricultural pollution and food prices. Evidence of their positive socio-economic impacts is at best inconclusive. ${ }^{528}$ The Global Subsidies Initiative has called for a stop of first generation biofuels governmental support, and a gradual removal of policies promoting their use. ${ }^{529}$ It is unclear whether all of these negative impacts make biofuels worse than fossil fuels. ${ }^{530}$ After all, fossil fuels have many environmental impacts other than GHG emissions, and their price fluctuation greatly affects the price of food. ${ }^{531}$ But not being worse than fossil fuels is not the standard here; biofuels have to be better and they currently do not appear to be so.

There is still hope, however, that second and third generation biofuels will provide a sustainable alternative to fossil fuels. Second generation biofuels made from

\footnotetext{
${ }^{528}$ HLPE, Biofuels and food security (Rome: High Level Panel of Experts on Food Security and Nutrition, 2013).

529 Ivetta Gerasinchuk, State of Play on Biofuel Subsidies: Are policies ready to shift? (Winnipeg: International Institute for Sustainable Development, 2012) at 22-23.

${ }_{530}$ However, Chris Charles et al, Biofuels - At What Cost? A review of costs and benefits of EU biofuel policies (Winnipeg: International Institute for Sustainable Development, 2013) at 100, indicate that biofuels score worse than fossil fuels on environmental and health indicators.

531 Björn Pieprzyk et al, The impact of fossil fuels - Greenhouse gas emissions, environmental consequences and socio-economic effects, Final Report, era - energy research architecture, November 2009; David Victor, The Politics of Fossil-Fuel Subsidies (Winnipeg: International Institute for Sustainable Development, 2009); FAO, The State of Food Insecurity in the World (Rome: Food and Agriculture Organization, 2010) at 9-10; and Siwa Msangi \& Mandy Ewing, "Food, Feed, or Fuel?" (2008) 9 Geo J Int'l Aff 17 at 21-22.
} 
waste and residues, for example, show great GHG emissions savings potential. ${ }^{532}$ In addition, they do not compete, in most cases, with other products, specifically agricultural ones, and thus should have an extremely limited to non-existent impact on food security. They also would not or would minimally cause agricultural pollution. Algae-based biofuels also appear to have very limited impacts on the environment. Such biofuels would definitely not compete with agricultural products and thus would not impact food security. Those advanced biofuels have great potential, but they both need a great deal more research and development before they can be sustainably mass produced to a level where they can compete with fossil fuels. ${ }^{533}$ Nonetheless, they show that biofuels should not be discarded altogether as a potential climate change mitigation tool, as recognised by the Intergovernmental Panel on Climate Change. ${ }^{534}$ It is rather the reliance on and promotion of first generation biofuels that should be questioned.

\subsection{A Sustainable Renewable Energy Directive: Recommendations}

Any recommendation at the EU level has to take into account the political structure of the supranational organisation. Making recommendations that would be outright rejected by one of the three key EU legislative players would be futile. I have thus attempted to craft my recommendations around what would be acceptable to the EU institutions or at least could be argued effectively before them. I have also taken into

\footnotetext{
${ }^{532}$ See Chapter 4, Section 3.2; and IUCN, A Global Assessment of the Environmental and Social Impacts Caused by the Production and Use of Biofuels (Gland: International Union for the Conservation of Nature, 2014) at 21-22.

${ }^{533}$ IUCN, ibid at 22; Joyce Tait et al, Biofuels: ethical issues (London: Nuffield Council on Bioethics, 2011), at 46-63; and Sjors van Iersel et al, Algae-based Biofuels: A Review of Challenges and Opportunities for Developing Countries (Rome: Food and Agriculture Organisation, 2009) at 42-43.

${ }^{534}$ Pete Smith et al, "2014: Agriculture, Forestry and Other Land Use (AFOLU)", in IPCC, Climate Change 2014: Mitigation of Climate Change (Cambridge: Cambridge University Press, 2014) at 870-886. See also IUCN, ibid.
} 
consideration the limits of EU power. In this particular situation, I have inferred from the Commission's ILUC Proposal and its subsequent discussion and amendments by all institutions, the position on and openness to biofuels reform of each institution. ${ }^{535}$ The Commission and the Parliament seem both quite open to address the sustainability issue of first generation biofuels. On the other hand, the Council - notably France, Spain and Poland - appears unwilling to adopt harsh measures limiting first generation biofuels.

At this point in time, the only viable solution is to drop the Renewable Energy Directive's mandatory target for the transportation sector until such a time when sustainable use of biofuels can actually be achieved. ${ }^{536}$ Without the target, the incentive to encourage the promotion, production and use of biofuels will disappear, and with it many of the negative impacts, except potentially for member states with a clear economic interest in the industry. Member states wishing to continue promoting first generation biofuels will be able to do so (although the incentive may diminish without the mandatory target). For them, the Commission has ways to take into account ILUC GHG emissions in the sustainability criteria; the best is probably to include estimates of ILUC GHG emissions per feedstock in the Renewable Energy Directive's GHG emissions lifecycle assessment methodology and estimates. ${ }^{537}$ Finding the appropriate way to integrate such GHG emissions might prove difficult due to lack of scientific consensus

535 See EU, European Parliament, Legislative Observatory, Fuels and energy from renewable sources: transition to biofuels to deliver greenhouse gas savings, 2012/0288(COD), online: www.europarl.europa.eu $<$ http://www.europarl.europa.eu/oeil/popups/ficheprocedure.do?lang=en\&reference=2012/0288(COD) $>$.

536 Jolene Lin, "The Environmental Regulation of Biofuels: Limits of the Meta-Standard Approach" (2011) 5 CCLR 34, at 42-43; Charles et al, supra note 530 at 101; and UN Special Rapporteur on the right to food, Note on the Impacts of the EU Biofuels Policy on the Right to Food, United Nations, Office of the High Commissioner for Human Rights, 23 April 2013, online: www.srfood.org < http://www.srfood.org/fr/special-rapporteur-urges-phase-out-of-eu-biofuel-incentives $>$ [Special Rapporteur].

537 Seita Romppanen, "Regulating Better Biofuels for the European Union" (2012) 21 Eur Energy \& Env L Rev 123 at 130-132; and EU, Report from the Commission on indirect land-use change related to biofuels and bioliquids, 22 December 2010, $\operatorname{COM}(2010) 811$. 
and EU political tensions, but without this step and considering the precautionary principle, the legitimacy of the sustainability criteria is questionable. The removal of the mandatory target, the integration of ILUC into the Directive's methodology and the 7\% cap for first generation biofuels should considerably limit the negative impacts of EU biofuels production.

The EU will also have to continue its efforts to improve water quality and protect biodiversity, especially regarding the agroindustry and the EU's effort to "green" the CAP. ${ }^{538}$ Some improvements have already been made for the 2014-2020 period, with mandatory maintenance of permanent grasslands and additional penalties for noncompliance with environmental requirements. ${ }^{539}$ Since enforcement of EU environmental law is not applicable to foreign states, the EU should envisage the adoption of further sustainability criteria dealing with agricultural pollution. This could manifest itself in requiring compliance with national, regional and local environmental law, and requiring the use of management plans with set environmental objectives, through voluntary schemes, which are already used as a mean of ensuring compliance with the sustainability criteria. ${ }^{540}$ As for social impacts, a similar approach can be employed by using already existing legal instruments and management plans as minimal standards, instead of simply listing states that ratified certain core ILO Conventions. ${ }^{541}$ For now, it seems the most

\footnotetext{
${ }^{538}$ See EU, Commission, Renewable energy progress report, 27 March 2013, COM(2013) 175 at 11; Kaley Hart \& David Baldock, Greening the CAP: Delivering Environmental Outcomes through Pillar One (London: Institute for European Environmental Policy, 2011); and EEA, Agriculture and the green economy (Copenhagen: European Environmental Agency, 2012).

539 EU, Commission, CAP Reform - an explanation of the main elements, 26 June 2013, online: ww.europa.eu < http://europa.eu/rapid/press-release_MEMO-13-621_en.htm >.

${ }^{540}$ Rocio Diaz-Chavez et al, Mandatory requirements in relation to air, soil, or water protection: analysis of need and feasibility, Final Report - Tasks 3 \& 4 (Utrecht: ECOFYS, 2013) at 53 \& 106-108.

${ }^{541}$ Some voluntary schemes already address social issues: Aziz Elbehri, Ana Segerstedt \& Pascal Liu, Biofuels and the sustainability challenge: A global assessment of sustainability issues, trends and policies for biofuels and related feedstocks (Rome: Food and Agriculture Organisation, 2013) at 119-122. See also
} 
realistic option due to the previous rejection by the Commission and the Council of any hard standards on social issues.

Production of advanced biofuels is currently insignificant in the EU. ${ }^{542}$ It will thus be in the interest of the EU to continue and intensify support of research and development of the more environmentally friendly second and third generation of biofuels. ${ }^{543}$ The EU should also consider stopping or at least progressively reducing most of its financial support of first generation biofuels and insure that future financing is tied with the environmental performance of biofuels, especially GHG emissions savings. ${ }^{544}$ Since it seems unlikely that the EU will be able to adopt a carbon tax in the near future, it could consider extending the EU Emissions Trading System to large and medium scale agricultural production to internalize environmental costs and encourage reduction of GHG emissions in that sector. ${ }^{545}$ Additionally, more research will be needed to effectively address the remaining uncertainties of biofuels production: ILUC impacts, water quality, social impacts and food security. ${ }^{546}$ Finally, the Commission should consider extending the sustainability criteria to all biofuels consumed in the EU to avoid creating a parallel and even less sustainable biofuels market. Until such changes are

UN Special Rapporteur on the Right to Food, Report of the Special Rapporteur on the right to food Agribusiness and the right to food, HRC, $13^{\text {th }}$ Sess, UN Doc A/HRC/13/33, (2009).

${ }^{542}$ Charles et al, supra note 530 at 98; and ECOFYS et al, Renewable energy progress and biofuels sustainability, Report submitted to the European Commission, September 2012, at 201.

${ }^{543}$ Charles et al, ibid at 101; and Didier Bourguignon, EU biofuels policy - Dealing with indirect land use change (Brussels: European Parliamentary Research Service, 2015).

${ }^{544}$ Charles et al, ibid at 101-102.

${ }^{545}$ Suzi Kerr and Andrew Sweet, "Inclusion of Agriculture in a Domestic Emissions Trading Scheme: New Zealand's Experience to Date" (2008) 5:4 Farm Policy Journal 19.

${ }^{546}$ IUCN, supra note 532 at 20; Special Rapporteur, supra note 536; EU, Commission, Proposal for a Directive of the European Parliament and of the Council amending Directive 98/70/EC relating to the quality of petrol and diesel fuels and amending Directive 2009/28/EC on the promotion of the use of energy from renewable sources, 17 October 2012, COM(2012) 595; and EU, Commission Staff Working Document Accompanying the document Renewable energy progress report, 27 March 2013, SWD(2013) 102, at 21 [2013 Progress Report SWD]. 
made, this thesis' principled lifecycle assessment indicates that the biofuels provisions of the Renewable Energy Directive are not sustainable.

\section{General Conclusion}

This thesis set out to determine, in its modest way, if the Renewable Energy Directive provided for the sustainable production of biofuels within the EU. I wished through it to identify the flaws of the Directive and thus propose some changes. The previous section did just that, but after a long journey it is useful to recapitulate the process that lead me to determine that the Directive did not achieve its goal of sustainability. In this final section, I offer a concluding summary of this thesis and some research ideas to complete the picture it painted.

\subsection{Dreaming of Sustainability: The Renewable Energy Directive}

The EU has been a leader in climate change mitigation. ${ }^{547}$ One of its actions in this field has been the promotion of renewable energy. This has culminated in 2009 by the adoption of the Renewable Energy Directive. The Directive promotes renewable energy by imposing a mandatory target of $20 \%$ renewables in final energy consumption, and a sub-target of $10 \%$ for the road transportation sector. Cognisant of the potentially negative effects of biofuels, which would be the main source of energy used to meet the sub-target, the EU imposed sustainability criteria for biofuels. The criteria mainly imposes minimal GHG emissions savings, limits on the origin of feedstocks to limit

547 Sebastian Oberthür \& Claire Roche Kelly, "EU Leadership in International Climate Policy: Achievements and Challenges" (2008) 43:3 The International Spectator: Italian Journal of International Affairs 35 . 
degradation of highly biodiverse land and land with high carbon stocks, and, for feedstocks cultivated in the EU, environmental cross-compliance obligations. Compliance with these criteria is mainly achieved through approved voluntary schemes. The Directive was amended by the ILUC Directive to partially deal with ILUC through a $7 \%$ cap for first generation biofuels.

The Renewable Energy Directive does not, however, operate in a vacuum. The production of biofuels is also regulated through other EU legislation. The price of biofuels is affected by customs duties and countervailing measures adopted by the EU and by taxes adopted by member states in accordance with the Energy Taxation Directive. The production of feedstocks is also subject to various environmental obligations, such as the ones found in the Birds Directive and the Habitats Directive concerning biodiversity, and the ones found in the Nitrates Directive and the Water Framework Directive concerning agricultural pollution. The Renewable Energy Directive is also part of a broader climate change policy that includes a decarbonisation target for fuels through the Fuel Quality Directive, GHG emissions cap and trade for many sectors including aviation through the EU ETS, and energy efficiency obligations through the Energy Efficiency Directive.

\subsection{Achieving Sustainability? A Principled Lifecycle Assessment}

Since the Renewable Energy Directive makes sustainability one of its cornerstones, it is appropriate to use sustainable development as the defining concept guiding the evaluation of the Directive's suitability. Furthermore, sustainable development is an established concept of international law. While its exact status is still 
up for debate, it occupies a prominent place in the EU legal order and in its international obligations, notably in the United Nations Framework Convention on Climate Change. Its usefulness is furthered by the complexity of issues and the multiple impacts surrounding biofuels. After all, sustainable development's goal is to reconcile current and future economic development with environmental and social considerations.

But how does one proceed to measure a Directive against sustainable development, a very broad concept? Firstly, through an appropriate approach; secondly, through the selection and definition of more concrete sustainable development principles. The chosen approach is based on lifecycle assessment. Not only is this methodology, geared towards measuring impacts of products from cradle to grave, widely used for biofuels, but it is the main methodology used by the Renewable Energy Directive itself in calculating GHG emissions for biofuels. As a primarily scientific methodology, lifecycle assessment is not necessarily designed for legal analysis. That is where the sustainable development principles come into play. They serve as the barometer to determine the sustainability of the legislative provisions of the Renewable Energy Directive and its framework. Finally the assessment is also based on data on the lifecycle environmental and socio-economic impacts of EU biofuels production.

The assessment itself is twofold. The first part is based on the core principle of sustainable devolvement, the principle of integration. It looks at the meaningful integration of the three pillars of sustainable development - economic development, environmental protection and social justice - by the Directive and its framework. Environmental concerns associated with biofuels were fairly well integrated through the sustainability criteria and other applicable environmental legislation. The one main 
caveat was the less stringent requirements for foreign biofuels and feedstocks. Economic development, especially through the mandatory target and favourable fiscal measures, was also meaningfully considered. Integration was much less meaningful when it came to social measures. While the EU is covered by various measures pertaining to social justice, it is not necessarily the case for foreign states, who are only covered in the Directive by reporting and monitoring obligations. Overall, there is a good but limited integration of the pillars.

The second part is more substantive and looks at the data on biofuels impacts to determine if EU provisions applicable to biofuels mitigate those impacts properly. The principle of equity was used for this part. This principle can be divided into intergenerational equity and intra-generational equity. Inter-generational equity is concerned with long-term and adverse impacts on the environment that would prevent future generation from enjoying a similar environment as the current generation. Intragenerational equity is concerned with the fair and equitable enjoyment of resources by the current generation. The polluter pays principle - which requires that polluters bear the financial burden of their pollution - was also used to measure relevant economic provisions. Uncertainties were dealt with according to the precautionary principle, which provides that scientific uncertainties should not stand in the way of environmental protection. The data showed that even with the Renewable Energy Directive and other measures in place, the production of biofuels in the EU would result in adverse environmental impacts through dubious and potentially non-existent or negative GHG emissions savings, and further degradation of biodiversity and water quality, both in the EU and abroad. Additionally, biofuels production will also likely result in negative 
impacts on intra-generational equity through increased food insecurity, and poor labour rights and standards in many biofuels/feedstocks exporting countries. Finally, fiscal support of the biofuels industry is not linked in any significant way with environmental concerns, and the environmental costs of biofuels production are not internalized.

Therefore, the conclusion of this principled lifecycle assessment is that the Renewable Energy Directive will not result in the sustainable production of biofuels. The sustainability criteria are no sufficient to deal with the social and environmental concerns associated with biofuels. The EU regulation of biofuels must change if the supranational organisation is truly committed to climate change mitigation. However, I choose to stay optimistic. There are many ways to limit the effects of climate change. None alone is a miracle or even a viable solution. To tackle this complicated environmental problem the international community will have to adopt concerted efforts on many fronts, including biofuels, other renewable energy, reduction of consumption, and energy efficiency. The task at hand is monumental, which is why I believe potential solutions should not be discarded lightly.

\subsection{The Road Ahead: Next Research Steps}

Knowing that the Renewable Energy Directive does not quite make the cut does not end the discussion on the sustainable development of biofuels. There are many ways to continue legal research on the sustainability of biofuels legislation. Conducting further principled lifecycle assessments in other states could prove useful to compare regime and identify best practices. Even more useful would be to concentrate on the major exporter states to draw an even more complete picture of the sustainability of the EU regime, and 
provide for some comparisons. Another option would be to delve deeper into the politics of each member states, the Commission, and the Parliament regarding biofuels. This would help determine in greater detail why reforms are slow, and what could be done to increase their speed and effectiveness. Specifically, it would complement the recommendation section of this thesis.

With regards to the Renewable Energy Directive itself, further research on implementation and compliance is needed. While compliance or implementation will not change the conclusion of this thesis as member states cannot adopt more stringent criteria for biofuels, they still provide information on how the regime functions on the ground and may offer enlightening variations between member states' implementation. For example, the EU study on biofuels' GHG emissions savings, including ILUC impacts, in Section 3.1 of Chapter 4 shows that in some circumstances first generation biofuels do provide for some non-negligible GHG emissions reduction compared to fossil fuels. The Commission also noted issues regarding the heterogeneous application of the criteria and the Directive's methodology. ${ }^{548}$ Furthermore, compliance plays a big role in the success of any biofuels regime. Additional research on the effectiveness of the voluntary scheme mechanism of compliance installed by the Directive is thus needed. ${ }^{549}$

Since biofuels are not going anywhere in the foreseeable future, all of these further research options would help shed light on the issue of biofuels production and help us identify what can be done, legislatively, to increase the sustainability of biofuels

\footnotetext{
5482013 Progress Report SWD, supra note 546 at 19-20; and EU, Communication from the Commission on the practical implementation of the EU biofuels and bioliquids sustainability scheme and on counting rules for biofuels, [2010] OJ, C 160/8.

${ }^{549}$ Lin, supra note 536 at 43; Seita Romppanen, "The EU's Biofuels: Certified as Sustainable?" (2012) 3:3 Renewable Energy L \& Pol'y Rev 173 at 185-186; and Elbehri, Segerstedt \& Liu, supra note 541 at 143148.
} 
in the EU and elsewhere. This thesis found that in its current form, the biofuels regulatory regime of the EU is not sustainable; but that is not the end of the discussion, only the beginning. 


\section{Bibliography}

\section{Legislation}

EC, Commission Decision 1999/272 of 9 December 1998 on the measure planned by Austria for the clean-up of the Kiener Deponie Bachmanning landfill, [1999] OJ, L $109 / 51$.

EC, Commission Decision 2009/548 of 30 June 2009 establishing a template for National Renewable Energy Action Plans under Directive 2009/28/EC of the European Parliament and of the Council, [2009] OJ, L 182/33.

EC, Commission Regulation 2454/93 of 2 July 1993 laying down provisions for the implementation of Council Regulation 2913/92 establishing the Community Customs Code, [1993] OJ, L 253/1.

EC, Council Decision 98/352 of 18 May 1998 concerning a multiannual programme for the promotion of renewable energy sources in the Community (Altener II), [1998] OJ, L $159 / 53$.

EC, Council Decision 1999/468 of 28 June 1999 laying down the procedures for the exercise of implementing powers conferred on the Commission, [1999] OJ, L 184/23 as amended by EC, Council Decision 2006/512 of 17 July 2006, [2006] OJ, L 200/11.

EC, Council Directive 2003/96 of 27 October 2003 restructuring the Community framework for the taxation of energy products and electricity, [2003] OJ, L 283/51.

EC, Council Regulation 73/2009 of 19 January 2009 establishing common rules for direct support schemes for farmers under the common agricultural policy and establishing certain support schemes for farmers, amending Regulations (EC) No 1290/2005, (EC) No 247/2006, (EC) No 378/2007 and repealing Regulation (EC) No 1782/2003, [2009] OJ, L 30/16.

EC, Council Regulation 598/2009 of 7 July 2009 imposing a definitive countervailing duty and collecting definitively the provisional duty imposed on imports of biodiesel originating in the United States of America, [2009] OJ, L 179/1.

EC, Council Regulation 599/2009 of 7 July 2009 imposing a definitive anti-dumping duty and collecting definitively the provisional duty imposed on imports of biodiesel originating in the United States of America, [2009] OJ, L 179/26. 
EC, Council Regulation 1 225/2009 of 30 November 2009 on protection against dumped imports from countries not members of the European Community, [2009] OJ, L $343 / 51$.

EC, Council Regulation 2658/87 of 23 July 1987 on the tariff and statistical nomenclature and on the Common Customs Tariff, [1987] OJ, L 256/1.

EC, Council Regulation 2913/92 of 12 October 1992 establishing the Community Customs Code, [1992] OJ, L 302/1.

EC, Decision 646/2000 of the European Parliament and of the Council of 28 February 2000 adopting a multiannual programme for the promotion of renewable energy sources in the Community (Altener) (1998 to 2002), [2000] OJ, L 79/1.

EC, Decision 1513/2002 of the European Parliament and of the Council of 27 June 2002 concerning the sixth framework programme of the European Community for research, technological development and demonstration activities, contributing to the creation of the European Research Area and to innovation, [2002] OJ, L 232/1.

EC, Directive 96/92 of the European Parliament and of the Council of 19 December 1996 concerning common rules for the internal market in electricity, [1996] OJ, L $27 / 20$.

EC, Directive 98/70 of the European Parliament and of the Council of 13 October 1998 relating to the quality of petrol and diesel fuels and amending Council Directive 93/12, [1998] OJ, L 350/58, as amended by Directives 2000/71, 2003/17, 2009/30 \& 2011/63, and by Regulation 1882/2003 (consolidated version of 2011).

EC, Directive 2000/60 of the European Parliament and of the Council of 23 October 2000 establishing a framework for Community action in the field of water policy, [2000] OJ, L 327/1, as amended by Decision 2455/2001, and Directives 2008/32, 2008/105, 2009/31 \& 2013/39 (consolidated version of 2013).

EC, Directive 2001/77 of the European Parliament and of the Council of 27 September 2001 on the promotion of electricity produced from renewable energy sources in the internal electricity market, [2001] OJ, L 283/33.

EC, Directive 2003/30 of the European Parliament and of the Council of 8 May 2003 on the promotion of the use of biofuels or other renewable fuels for transport, [2003] OJ, L $123 / 42$.

EC, Directive 2003/87 of the European Parliament and of the Council of 13 October 2003 establishing a scheme for greenhouse gas emission allowance trading within the Community and amending Council Directive 96/61/EC, [2003] OJ, L 275/32, as 
amended by Directives 2004/101, 2008/101, 2009/29, by Regulation 219/2009 and by the Treaty of Accession of Croatia (consolidated version of 2011).

EC, Directive 2009/28 of the European Parliament and of the Council of 23 April 2009 on the promotion of the use of energy from renewable sources and amending and subsequently repealing Directives 2001/77/EC and 2003/30/EC, [2009] OJ, L $140 / 16$.

EC, Directive 2009/125 of the European Parliament and of the Council of 21 October 2009 establishing a framework for the setting of ecodesign requirements for energyrelated products, [2009] OJ, L 285/10.

EC, Directive 2009/147 of the European Parliament and of the Council of 30 November 2009 on the conservation of wild birds, [2009] OJ, L 20/7, as amended by Directive 2013/17 (consolidated version of 2013).

EC, Regulation 1099/2008 of the European Parliament and of the Council of October 2008 on energy statistics, [2008] OJ, L 304/1.

EEC, Council Decision 93/500 of 13 September 1993 concerning the promotion of renewable energy sources in the Community, [1993] OJ, L 235/41.

EEC, Council Directive 79/409 of 2 April 1979 on the conservation of wild birds, [1979] OJ, L 103/1.

EEC, Council Directive 91/676 of 12 December 1991 concerning the protection of waters against pollution caused by nitrates from agricultural sources, [1991] OJ, L 375/1, as amended by Regulations 1882/2003 \& 1137/2008 (consolidated version of 2008).

EEC, Council Directive 92/43 of 21 May 1992 on the conservation of natural habitats and of wild fauna and flora, [1992] OJ, L 206/7, as amended by Directives 97/62, 2006/105 \& 2013/17, Regulation 1882/2003, the Act of Accession of Austria, Sweden and Finland, and the Act concerning the conditions of accession of the Czech Republic, the Republic of Estonia, the Republic of Cyprus, the Republic of Latvia, the Republic of Lithuania, the Republic of Hungary, the Republic of Malta, the Republic of Poland, the Republic of Slovenia and the Slovak Republic (consolidated version of 2013).

EEC, Council Directive 92/83 of 19 October 1992 on the harmonization of the structures of excise duties on alcohol and alcoholic beverages, [1992] OJ, L 316/21.

EU, Commission Decision 2010/335 of 10 June 2010 on guidelines for the calculation of land carbon stocks for the purpose of Annex V to Directive 2009/28/EC, [2010] OJ, L 151/19. 
EU, Commission Decision 2010/634 of 22 October 2010 adjusting the Union-wide quantity of allowances to be issued under the Union Scheme for 2013 and repealing Decision 2010/384/EU, [2010] OJ, L 279/34.

EU, Commission Decision 2011/149 of 7 March 2011 on historical aviation emissions pursuant to Article 3c(4) of Directive 2003/87/EC of the European Parliament and of the Council establishing a scheme for greenhouse gas emission allowance trading within the Community, [2011] OJ, L 61/42.

EU, Commission Implementing Regulation 1101/2014 of 16 October 2014 amending Annex I to Council Regulation 2658/87 on the tariff and statistical nomenclature and on the Common Customs Tariff, [2014] OJ, L 312/1.

EU, Commission Regulation 389/2013 of 2 May 2013 establishing a Union Registry pursuant to Directive 2003/87/EC of the European Parliament and of the Council, Decisions No 280/2004/EC and No 406/2009/EC of the European Parliament and of the Council and repealing Commission Regulations No 920/2010 and No 1193/201, [2013] OJ, L 122/1.

EU, Commission Regulation 601/2012 of 21 June 2012 on the monitoring and reporting of greenhouse gas emissions pursuant to Directive 2003/87/EC of the European Parliament and of the Council, [2012] OJ, L 181/30.

EU, Council Implementing Regulation 157/2013 of 18 February 2013 imposing a definitive anti-dumping duty on imports of bioethanol originating in the United States of America, [2013] OJ, L 49/10.

EU, Council Implementing Regulation 443/2011 of 5 May 2011 extending the definitive countervailing duty imposed by Regulation (EC) No 598/2009 on imports of biodiesel originating in the United States of America to imports of biodiesel consigned from Canada, whether declared as originating in Canada or not, and extending the definitive countervailing duty imposed by Regulation (EC) No $598 / 2009$ to imports of biodiesel in a blend containing by weight $20 \%$ or less of biodiesel originating in the United States of America, and terminating the investigation in respect of imports consigned from Singapore, [2011] OJ, L 122/1.

EU, Council Implementing Regulation 444/2011 of 5 May 2011 extending the definitive anti-dumping duty imposed by Regulation (EC) No 599/2009 on imports of biodiesel originating in the United States of America to imports of biodiesel consigned from Canada, whether declared as originating in Canada or not, and extending the definitive antidumping duty imposed by Regulation (EC) No 599/2009 to imports of biodiesel in a blend containing by weight $20 \%$ or less of biodiesel originating in the 
United States of America, and terminating the investigation in respect of imports consigned from Singapore, [2011] OJ, L 122/12.

EU, Council Implementing Regulation 1194/2013 of 19 November 2013 imposing a definitive anti-dumping duty and collecting definitively the provisional duty imposed on imports of biodiesel originating in Argentina and Indonesia, [2013] OJ, L 315/2.

EU, Directive 2010/31 of the European Parliament and of the Council of 19 May 2010 on the energy performance of buildings, [2010] OJ, L 153/13.

EU, Directive 2012/27 of the European Parliament and of the Council of 25 October 2012 on energy efficiency, amending Directives 2009/125/EC and 2010/30/EU and repealing Directives 2004/8/EC and 2006/32/EC, [2012] OJ, L 315/1.

EU, Directive 2015/1513 of the European Parliament and of the Council of 9 September 2015 amending Directive 98/70/EC relating to the quality of petrol and diesel fuels and amending Directive 2009/28/EC on the promotion of the use of energy from renewable sources, [2015] OJ, L 239/1.

EU, Regulation 182/2011 of the European Parliament and of the Council of 16 February 2011 laying down the rules and general principles concerning mechanisms for control by Member States of the Commission's exercise of implementing powers, [2011] OJ, L 55/13.

EU, Regulation 952/2013 of the European Parliament and of the Council of 9 October 2013 laying down the Union Customs Code, [2013] OJ, L 269/1.

EU, Regulation 978/2012 of the European Parliament and of the Council of 25 October 2012 applying a scheme of generalised tariff preferences and repealing Council Regulation 732/2008, [2012] OJ, L 303/1.

European Economic Area, Decision of the EEA Joint Committee 87/2011 of 1 July 2011 amending Annex XX (Environment) to the EEA Agreement, EEA Supplement No 54, (2011).

\section{Treaties and Declarations}

Agreement on the European Economic Area, 2 May 1992, [1994] OJ, L 1/3.

Cartagena Protocol on Biosafety, 29 January 2000, 2226 UNTS 208.

Charter of Fundamental Right of the European Union, [2012] OJ, C 326/391.

Convention for the Protection of Human Rights and Fundamental Freedoms, 4 November 1950, 213 UNTS 221. 
Convention for the Protection of the Marine Environment of the North-East Atlantic, 22 September 1992, 32 ILM 1069.

Convention on Biological Diversity, 5 June 1992, 1760 UNTS 79.

Convention on International Trade in Endangered Species of Wild Fauna and Flora, 3 March 1973, 993 UNTS 3.

Convention on the Protection of the Marine Environment of the Baltic Sea Area, 9 April 1992, 13 ILM 546.

Convention on the Transboundary Effects of Industrial Accidents, 18 March 1992, 32 ILM 1330.

International Convention on Oil Pollution, Preparedness, Response and Cooperation, 30 November 1990, 30 ILM 733.

Johannesburg Declaration on Sustainable Development, Report of the WSSD, UNOR, UN Doc A/Conf 199/20, (2002), Resolution 1.

Montreal Protocol on Substances that Deplete the Ozone Layer, 16 September 1987, 1522 UNTS 3.

Protocol on Water and Health to the 1992 Convention on the Protection and Use of Transboundary Watercourses and International Lakes, 17 June 1999, 2331 UNTS 202.

Rio Declaration on Environment and Development, annex of the Report of the United Nations Conference on Environment and Development, 3 June 1992, UN Doc A/CONF. 151/26/Rev. I (Vol. I), Annex I.

Stockholm Convention on Persistent Organic Pollutants, 22 May 2001, 2256 UNTS 119.

Stockholm Declaration on the Human Environment, 16 June 1972, UNDocA/CONF/48/14/REV.1.

The Single European Act, 17 February 1986, [1987] OJ, L 169.

Treaty establishing the European Atomic Energy Community, [2010] OJ, C 84/1.

Treaty establishing the European Community, 31 August 1992, [1992] OJ, C 224/1.

Treaty establishing the European Economic Community, 25 March 1957, 298 UNTS 11.

Treaty of Lisbon amending the Treaty on European Union and the Treaty establishing the European Community, 13 December 2007, [2007] OJ, C 306/01. 
Treaty on European Union, 13 December 2007, [2010] OJ, C 83/13.

Treaty on the Functioning of the European Union, 13 December 2007, [2010] OJ, C 83/47.

United Nations Framework Convention on Climate Change, 9 May 1992, 1771 UNTS 107.

\section{Jurisprudence}

Air Transport Association of America and Others $v$ Secretary of State for Energy and Climate Change, C-366/10, [2011] ECR I-13833.

Amministrazione delle finanze dello Stato v Simmenthal, C-106/77, [1978] ECR 629.

Arbitration regarding the Iron Rhine (Ijzeren Rijn) Railway, Belgium v Netherlands, (2005) Arbitral Award of 24 May 2005, Reports of International Arbitral Awards Vol. XXVII pp 35-125.

Association pour la protection des animaux sauvages v Préfet de Maine-et-Loire and Préfet de la Loire-Atlantique, C-435/92, [1994] I-67.

Case concerning the Gabcikovo-Nagymaros Project (Hungary v Slovakia), Judgment, [1997] ICJ Rep 7.

Case Concerning Maritime Delimitation in the Area Between Greenland and Jan Mayen (Denmark v Norway), [1993] ICJ Rep 38.

Commission v Austria, C-209/04, [2006] ECR I-2755.

Commission v Belgium, C-221/03, [2005] ECR I-8307.

Commission v Belgium, C-247/85, [1987] ECR 3029.

Commission v Council, C-155/91, [1993] ECR I-963.

Commission v Council, C-370/07, [2009] ECR I-8917.

Commission v Denmark, C-302/86, [1988] ECR 4607.

Commission v France, C-96/98, [1999] ECR I-8531.

Commission v France, C-202/01, [2002] ECR I-11019.

Commission v France, C-220/99, [2001] ECR I-5831.

Commission v France, C-258/00, [2002] ECR I-5959. 
Commission v France, C-280/02, [2004] ECR I-8573.

Commission v Germany, C-57/89, [1991] ECR I-883.

Commission v Germany, C-71/99, [2001] ECR I-5811.

Commission v Germany, C-131/88, [1991] ECR I-825.

Commission v Germany, C-161/00, [2002] ECR I-2753.

Commission v Greece, C-103/00, [2002] ECR I-1147.

Commission v Greece, C-375/95, [1997] ECR I-5981.

Commission v Ireland, C-67/99, [2001] ECR I-5757.

Commission v Ireland, C-117/00, [2002] ECR I-5335.

Commission v Ireland, C-396/01, [2004] ECR I-2315.

Commission v Italy, C-92/79, [1980] ECR 1115.

Commission v Italy, C-159/78, [1979] ECR 3247.

Commission v Italy, C-173/05, [2007] ECR I-4917.

Commission v Italy, C-262/85, [1987] ECR 3073.

Commission v Italy, C-304/05, [2007] ECR I-7495.

Commission v Luxembourg, C-32/05, [2006] ECR I-11323.

Commission v Netherlands, C-3/96, [1998] ECR I-3031.

Commission v Netherlands, C-322/00, [2003] ECR I-11267.

Commission v Parliament and Council, C-178/03, [2006] ECR I-129.

Commission v Spain, C-355/90, [1993] ECR I-4221.

Commission v United Kingdom, C-6/04, [2005] ECR I-9017.

Commission v United Kingdom, C-69/99, [2000] ECR I-10979.

Costa v ENEL, C-6/64, [1964] ECR 585.

EC Measures Concerning Meat and Meat Products (Hormones) (1998), WT/DS26/AB/R and WT/DS48/AB/R. 
Evroetil AD v Direktor na Agentsia 'Mitnitsi', C-503/10, [2011] I-14209.

Faccini Dori v Recreb, C-91/92, [1994] ECR I-3325.

Fratelli Costanzo v Comune di Milano, C-103/88, [1989] ECR 1861.

Freskot AE v Elliniko Dimosio, C-355/00, [2003] ECR I-5263.

Internationale Handelsgesellschaft mbH $v$ Einfuhr- und Vorratsstelle für Getreide und Futtermittel, C-11/70, [1970] ECR 1125.

Koninklijke Scholten Honing v Council and Commission, C-101/76, [1977] ECR 797.

Legality of the Threat or Use of Nuclear Weapons Case, Advisory Opinion, [1996] ICJ Rep 226.

Marshall v Southampton and South-West Hampshire Area Health Authority, C-152/84, [1986] ECR 723.

Ministero delle Finanze v IN.CO.GE.'90, C-10/97 to C-22/97, [1998] ECR I-6307.

Mondiet v Armement Islais, C-405/92, [1993] ECR I-6133.

Parliament v Council, C-70/88, [1991] ECR I-4529.

Parliament v Council, C-187/93, [1994] ECR I-2857.

Pfizer Animal Health SA v Council of the European Union, T-13/99, [2002] ECR II-3305.

Plantanol GmbH \& Co KG v Hauptzollamt Darmstadt, C-201/08, [2009] ECR I-8343.

PreussenElektra v Schhleswag, C-379/98, [2001] ECR I-2099.

Procureur de la République v ADBHU, C-240/83, [1985] ECR 531.

$R v$ Secretary of State for the Environment, ex parte Royal Society for the Protection of Birds, C-44/95, [1996] ECR I-3805.

Request for an Examination of the Situation in Accordance with Paragraph 63 of the Court's Judgment of 20 December 1974 in the Nuclear Tests (New Zealand $v$ France) Case, [1995] ICJ Rep 288.

Sociedad Cooperativa General Agropecuaria (ACOR) v Administración General del Estado, C-416/01, [2003] I-14083..

Southern Bluefin Tuna Cases (Order), (1999) ITLOS Nos 3\&4. 
Syndicat national des fabricants raffineurs d'huile de graissage et al v Groupement d'intérêt économique "Inter-Huiles" et al, C-172/82, [1983] ECR 555.

The Queen v Ministry of Agriculture, Fisheries and Food, et al, C-157/96, [1998] ECR I2211.

The Queen v Minister of Agriculture, Fisheries and Food, ex parte Standley, C-293/97, [1999] ECR I-2603.

The Queen v Secretary of State for the Environment, Transport and the Regions, ex parte First Corporate Shipping, C-371/98, [2000] ECR I-9235.

The Queen v Secretary of State for Transport, ex parte Factortame, C-213/89, [1990] ECR I-2433.

United Kingdom v Commission, C-180/96, [1998] ECR I-02265.

United Kingdom v Council, C-68/86, [1988] ECR 855.

US - Taxes on Petroleum and Certain Imported Substances (1987), GATT Doc L/6175, BISD 34S/136.

Van Gend en Loos v Nederlandse Administratie der Belastingen, C-26/62, [1963] ECR 1.

Waddenvereniging and Vogelsbeschermingvereniging $v$ Staatssecretaris van Landbouw, Natuurbeheer en Visserij, C-127/02, [2004] ECR I-7405.

Yusuf and Al Bakaraat International Foundation v Council and Commission, T-306/01, [2005] ECR II-3533.

\section{Secondary Materials}

\section{Monographs}

Arbour, Jean-Maurice \& Sophie Lavallée, Droit international de l'environnement (Cowansville, QC: Éditions Yvon Blais, 2006).

Atapattu, Sumudu A, Emerging Principles of International Environmental Law (New York: Transnational Publishers, 2006).

Benidickson, Jamie, Environmental Law, $3^{\text {rd }}$ ed (Toronto: Irwin Law, 2008).

Birnie, Patricia, Alan Boyle \& Catherine Redgwell, International Law \& the Environment (Oxford: Oxford University Press, 2009).

Bosselmann, Klaus, The Principle of Sustainability (Surrey, UK: Ashgate, 2008). 
Carlame, Cinnamon Piñon, Climate Change Law and Policy: EU and US Perspectives (Oxford: Oxford University Press, 2010).

Cordonier Segger, Marie-Claire \& Ashfaq Khalfan, Sustainable Development Law: Principles, Practices \& Prospects (Oxford: Oxford University Press, 2004).

Curtin, Deirdre, Executive Power of the European Union: Law, Practices, and the Living Constitution (Oxford: Oxford University Press, 2009).

Davies, Peter G G, European Union Environmental Law: An Introduction to Key Selected Issues (Burlington, VT: Ashgate Publishing, 2004).

de Sadeleer, Nicolas, Environmental Principles: From Political Slogans to Legal Rules (Oxford: Oxford University Press, 2002).

Edward, David \& Robert Lane, Edward and Lane on European Union Law (Cheltenham, UK: Edward Elgar, 2013).

Ericson, Richard et al, Representing Order: Crime, Law and Justice in the News Media (Toronto: University of Toronto Press, 1991).

Foster, Nigel, Foster on EU Law, $2^{\text {nd }}$ ed (Oxford: Oxford University Press, 2009).

French, Duncan, International Law and Policy of Sustainable Development (Manchester: Manchester University Press, 2005).

Jack, Brian, Agriculture and EU Environmental Law (Burlington, VT: Ashgate Publishing, 2009).

Jans, Jan H and Hans H B Vedder, European Environmental Law, $3^{\text {rd }}$ ed (Gorningen: Europa Law Publishing, 2008).

Kaczorowska, Alina, European Union Law, $3^{\text {rd }}$ ed (New York: Routledge, 2013).

Kiss, Alexandre \& Dinah Shelton, Guide to International Environmental Law (Leiden: Martinus Nijhoff, 2007).

Lee, Maria, EU Environmental Law: Challenges, Change and Decision-Making (Oxford: Hart Publishing, 2005).

Lenaerts, Koen, Piet Van Nuffel \& Robert Bray, ed, Constitutional Law of the European Union, $2^{\text {nd }}$ ed (London: Sweet \& Maxwell, 2005).

Louka, Elli, International Environmental Law: Fairness, Effectiveness, and World Order (Cambridge: Cambridge University Press, 2006). 
Martuzzi, Marco \& Joel A Tickner, eds, Precautionary Principle: protecting public health, the environment and the future of our children (Copenhagen: World Health Organization - Europe, 2004).

McCormick, John \& Jonathan Olsen, The European Union: Politics and Policies, $5^{\text {th }}$ ed (Boulder, CO: Westview Press, 2013).

Nanda, Ved P \& George W Pring, International Environmental Law and Policy for the 21st Century, $2^{\text {nd }}$ rev ed (Leiden: Martinus Nijhoff, 2013).

Sands, Philippe, Principles of International Environmental Law, $2^{\text {nd }}$ ed (Cambridge: Cambridge University Press, 2003).

Sands, Philippe \& Jacqueline Peel, Principles of International Environmental Law, 3rd ed (Cambridge: Cambridge University Press, 2012).

Schütze, Robert, An Introduction to European Law (Cambridge: Cambridge University Press, 2012).

Snape, John \& Jeremy de Souza, Environmental Taxation Law - Policy, Contexts and Practice (Burlington, VT: Ashgate Publishing, 2006).

Trouwborst, Arie, Evolution and Status of the Precautionary Principle in International Law (The Hague: Kluwer Law International, 2002).

Voigt, Christina, Sustainable Development as a Principle of International Law (Leiden: Martinus Nijhoff, 2009).

\section{Articles}

Adams, W M "Green Development Theory? Environmentalism and sustainable development" in Jonathan Crush, ed, Power of Development, (London: Routledge, 1995).

Armah, Paul, Aaron Archer \& Gregory C Phillips, "Drivers Leading to Higher Food Prices: Biofuels are not the Main Factor" in Dwight Tomes, Prakash Lakshmanan \& David Songstad, eds, Biofuels: Global Impact on Renewable Energy, Production Agriculture, and Technological Advancements (New York: Springer, 2011).

Avilès, Luis A, "Sustainable Development and the Legal Protection of the Environment in Europe" (2011) 12 Sustainable Dev L \& Pol'y 29.

Banerjee, Subhabrata Bobby, "Who Sustains Whose Development? Sustainable Development and the Reinvention of Nature" (2003) 24:1 Organization Studies 143. 
Belboom, Sandra, Bernard Bodson \& Angélique Léonard, "Does the production of Belgian bioethanol fit with European requirements on GHG emissions? Case of wheat" (2015) 74 Biomass \& Bioenergy 58.

Benson, David \& Andrew Jordan, “A Grand Bargain or an 'Incomplete Contract'? EU Environmental Policy after the Lisbon Treaty" (2008) 17 Eur Energy \& Env L Rev 280.

Blass, Harry \& Carolien Kroeze, "Possible future effects of large-scale algae cultivation for biofuels on coastal eutrophication in Europe" (2014) 496 Science of the Total Environment 45 .

Bodansky, Daniel, "Deconstructing the Precautionary Principle" in David D Caron, \& Harry N Scheiber, eds, Bringing New Law to Ocean Waters (Leiden: Martinus Nijhoff, 2004).

Bosselmann, Klaus, "Sustainable development and international environmental law" in Shawkat Alam, eds, Routledge Handbook of International Environmental Law (New York: Routledge, 2013).

Bratspies, Rebecca M, "Reconciling the Irreconcilable: Progress Toward Sustainable Development" in Russell A Miller \& Rebecca M Bratspies, Progress in International Law (Leiden: Martinus Nijhoff, 2008).

Brown Weiss, Edith, "Implementing Intergenerational Equity" in Malgosia Fitzmaurice, David M Ong \& Panos Merkouris, eds, Research Handbook on International Environmental Law (Cheltenham, UK: Edward Elgar Publishing, 2010).

__ "In Fairness to Future Generations and Sustainable Development" (1992) 18:1 American U Int'l L Rev 19.

Brunnée, Jutta, "The Stockholm Declaration and the Structure and Processes of International Environmental Law" in Aldo Chircop, Ted MecDorman \& Susan J Rolston, eds, The Future of Ocean Regime Building: Essays in Tribute to Douglas M. Johnston (Leiden: Martinus Nijhoff, 2009).

Calliess, Christian \& Christian Hey, "Renewable Energy Policy in the EU: A Contribution to Meet International Climate Protection Goals?" (2013) 88 Berliner Online-Beiträge zum Europarecht 1.

Cameron, James, "Future Directions in International Environmental Law: Precaution, Integration and Non-state Actors" (1996) 19 Dal LJ 122.

Cardwell, Mitchel, "European Union Agricultural Policy and Practice: The New Challenge of Climate Change" (2011) 13 Envtl L Rev 271. 
Chui, Wing Hong, "Quantitative Legal Research" in Mike McConville \& Wing Hong Chui, Research Methods for Law (Edinburgh: Edinburgh University Press, 2007).

Colbran, Nicola \& Asbjorn Eide, "Biofuel, the Environment, and Food Security: A Global Problem Explored Through a Case Study of Indonesia" (2008-2009) 9 Sustainable Dev L \& Pol'y 4.

Collins, Lynda, "Revisiting the Doctrine of Intergenerational Equity in Global Environmental Governance" (2007) 30 Dal LJ 79.

Cordonier Segger, Marie-Claire, "Sustainable Development in International Law" in David Armstrong, ed, Routledge Handbook of International Law (New York: Routledge, 2009).

—_, "Sustainable Development in International Law" in Hans Christian Bugge \& Christina Voigt, eds, Sustainable Development in International and National Law (Groningen: Europa Law Publishing, 2008).

de Búrca, Gráinne, "The European Court of Justice and the International Legal Order after Kadi” (2010) 51:1 Harv Int'l LJ 1.

de Cendra de Larragan, Javier, "EU climate and energy law: challenges for member states", in Marjan Peeters, Mark Stallworthy \& Javier de Cendra de Larragan, eds, Climate Law in EU Member States: Towards National Legislation for Climate Protection (Cheltenham, UK: Edward Elgar, 2012).

de Sadeleer, Nicolas, "EC Law and Biodiversity", in Richard Macrory, ed, Reflections on 30 Years of EU Environmental Law - A High Level of Protection? (Groningen: Europa Law Publishing, 2006).

—_ "The Principles of Prevention and Precaution in International Law: Two Heads of the Same Coin?" in Malgosia Fitzmaurice, David M Ong \& Panos Merkouris, eds, Research Handbook on International Environmental Law (Cheltenham, UK: Edward Elgar Publishing, 2010).

Del Guayo, Iñigo, "Biofuels: EU Law and Policy", in Don Zillman et al, eds, Beyond The Carbon Economy: Energy Law in Transition (Oxford: Oxford University Press, 2008).

Delvaux, Bram, "Promoting Biofuels in Energy Supply: the European Legal Framework" (2004) 13 Eur Env L Rev 66.

Dobinson, Ian \& Francis Johns, "Qualitative Legal Research" in Mike McConville \& Wing Hong Chui, Research Methods for Law (Edinburgh: Edinburgh University Press, 2007). 
Ellis, Jaye \& Stepan Wood, "International Environmental Law" in Benjamin Richardson \& Stepan Wood, eds, Environmental Law for Sustainability (Portland, OR: Hart Publishing, 2006).

Endres, Jody M, "Clearing the Air: The Meta-standard Approach to Ensuring Biofuels Environmental and Social Sustainability" (2010) 28 Va Envtl LJ 73.

French, Duncan, "Sustainable Development" in Malgosia Fitzmaurice, David M Ong \& Panos Merkouris, eds, Research Handbook on International Environmental Law (Cheltenham, UK: Edward Elgar Publishing, 2010).

Hancher, Leigh \& Francesco Maria Salerno, "Energy Policy after Lisbon", in Andrea Biondi, Piet Eeckhout \& Stefanie Ripley, eds, EU Law after Lisbon (Oxford: Oxford University Press, 2012).

Heijungs, Reinout \& Jeroen B Guinée, "An Overview of the Life Cycle Assessment Method - Past, Present, and Future", in Mary Ann Curran, ed, Life Cycle Assessment Handbook: A Guide for Environmentally Sustainable Products (Beverly, MA: Scrivener Publishing, 2012).

Hopwood, Bill, Mary Mellor \& Geoff O’Brien, "Sustainable development: mapping different approaches" (2005) 13 Sust Dev 38.

Humpenöder, Florian et al, "Effects of land-use change on the carbon balance of 1st generation biofuels: An analysis for the European Union combining spatial modeling and LCA” (2013) 56 Biomass \& Bioenergy 166.

Huppes, Gjalt \& Mary Ann Curran, "Environmental Life Cycle Assessment: Background and Perspective", in Mary Ann Curran, ed, Life Cycle Assessment Handbook: A Guide for Environmentally Sustainable Products (Beverly, MA: Scrivener Publishing, 2012).

Inglis, Kirstyn, "Anticipating New Union Competences in Energy" (2008) 15 Maastricht J Eur \& Comp L 125.

Johnston, Angus \& Eva van der Marel, "Ad Lucem? Interpreting the New EU Energy Provision, and in Particular the Meaning of Article 194(2)TFEU" (2013) 22 Eur Energy \& Env L Rev 181.

Kerr, Suzi and Andrew Sweet, "Inclusion of Agriculture in a Domestic Emissions Trading Scheme: New Zealand's Experience to Date" (2008) 5:4 Farm Policy Journal 19.

Klabbers, Jan, "International Law in Community Law: The Law and Politics of Direct Effect” (2002) 21 YB Eur L 263. 
Klemedtsson, Åsa Kasimir and Keith A Smith, "The significance of nitrous oxide emission due to cropping of grain for biofuel production: a Swedish perspective" (2011) 8 Biogeosciences 3581.

Kramer, Ludwig, "Sustainable Development in EC Law" in Hans Christian Bugge \& Christina Voigt, eds, Sustainable Development in International and National Law (Groningen: Europa Law Publishing, 2008).

Kravchenko, Svitlana, Tareq M R Chowdhury \& Md Jahid Hossain Bhuiyan, "Principles of International Environmental Law" in Shawkat Alam et al, eds, Routledge Handbook of International Environmental Law (New York: Routledge, 2013).

Lahire, Bernard, "Nécessité théorique et obligations empiriques" (2006) 27:1 Revue du MAUSS 444 .

Lardon, Laurent et al, "Life-Cycle Assessment of Biodiesel Production from Microalgae" (2009) 43:17 Environmental Science \& Technology 6475.

Larson, Eric D, "A review of life-cycle analysis studies on liquid biofuel systems for the transport sector" (2006) 10:2 Energy for Sustainable Development 109.

Leach, Matthew \& Sandip Deshmukh, "Sustainable Energy Law and Policy", in Karen E Makuch \& Ricardo Pereira, eds, Environmental and Energy Law (Chichester, UK: Wiley-Blackwell, 2012).

Lee, Maria, “The Environmental Implications of the Lisbon Treaty" (2008) 10 Env L Rev 131.

Lin, Jolene, "Governing Biofuels: A Principal-Agent Analysis of the European Union Biofuels Certification Regime and the Clean Development Mechanism" (2011) 24 J of Env L 43.

—_ "The Environmental Regulation of Biofuels: Limits of the Meta-Standard Approach” (2011) 5:1 CCLR 34.

Lindorfer, Johannes, Karin Fazeni \& Horst Steinmüller, "Life cycle analysis and soil organic carbon balance as methods for assessing the ecological sustainability of 2nd generation biofuel feedstock" (2014) 5 Sustainable Energy Technologies and Assessments 95.

Mayeda, Graham, "Where Should Johannesburg Take Us - Ethical and Legal Approaches to Sustainable Development in the Context of International Environmental Law" (2004) 15 Colo J Int'l Envtl L \& Pol'y 29. 
Mead, Stephanie Joan, "The Precautionary Principle: A Discussion of the Principle's Meaning and Status in an Attempt to Further Define and Understand the Principle" (2004) 8 NZ J Envtl L 137.

Msangi, Siwa \& Mandy Ewing, "Food, Feed, or Fuel?” (2008) 9 Geo J Int'l Aff 17.

Oberthür, Sebastian \& Claire Roche Kelly, "EU Leadership in International Climate Policy: Achievements and Challenges" (2008) 43:3 The International Spectator: Italian Journal of International Affairs 35.

Olazabal, Claudia, "Community Legislation on Water Protection: An Assessment of its Evolution and Possible Future", in Marco Onida, ed, Europe and the EnvironmentLegal Essays in Honour of Ludwig Krämer (Groningen: Europa Law Publishing, 2004).

Oschmann, Volker, "Renewable Energy Sources in European Law: an Overview" (2006) 3 J Eur Env \& Plan L 478.

Ottinger, Richard L, "Biofuels - Potentials, Problems \& Solutions" (2009) 19 Fordham Envtl L Rev 253.

Pearson, Charles S, “Testing the System: GATT + PPP = ?” (1994) 27 Cornell Int'l L J 553.

Pereira, Ricardo \& Charlotte Jourdain, "International and EU Climate Change Law", in Karen E Makuch \& Ricardo Pereira, eds, Environmental and Energy Law (Chichester, UK: Wiley-Blackwell, 2012).

Pohlmann, Markus, "The European Union Emissions Trading Scheme", in David Freestone \& Charlotte Streck, eds, Legal Aspects of Carbon Trading: Kyoto, Copenhagen, and beyond (Oxford: Oxford University Press, 2009).

Pyhala, Minna, Anne Christine \& Hanna Paulomaki, "The Precautionary Principle" in Malgosia Fitzmaurice, David M Ong, \& Panos Merkouris, eds, Research Handbook on International Environmental Law (Cheltenham, UK: Edward Elgar Publishing, 2010).

Ram, Melanie H, "Europeanized Hypocrisy: Roma Inclusion and Exclusion in Central and Eastern Europe" (2014) 13:3 Journal on Ethnopolitics and Minority Issues in Europe 15.

Rashbrooke, Gwenaele, "Clarification or Complication - The New Energy Title in the Draft Constitution for Europe" (2004) 22 J Energy \& Nat'1 Res L 373. 
Richardson, Benjamin J, "Economic Instruments in UK Environmental Law Reform: Is the UK Government Sending the Right Signals" (2001) 3 Eur JL Reform 431.

Romppanen, Seita, "Regulating Better Biofuels for the European Union" (2012) 21 Eur Energy \& Envtl L Rev 123.

—_ "The EU's Biofuels: Certified as Sustainable?" (2012) 3:3 Renewable Energy L \& Pol'y Rev 173.

Ross, Andrea, "Modern Interpretations of Sustainable Development" (2009) 36:1 JL \& Soc'y 32.

Sanderson, Fiona $\mathrm{J}$ et al, "Assessing the performance of EU nature legislation in protecting target bird species in an era of climate change" [2015] Conservation Letters.

Sari, Aurel, "The Relationship between Community Law and International Law after Kadi: Did the ECJ Slam the Door on Effective Multilateralism?" in Matthew Happold, ed, International Law in a Multipolar World (London: Routledge, 2011).

Schwartz, Priscilla, "The Polluter-pays Principle” in Malgosia Fitzmaurice, David M Ong \& Panos Merkouris, eds, Research Handbook on International Environmental Law (Cheltenham, UK: Edward Elgar Publishing, 2010).

Sevigné Itoiz, Eva et al, "Energy balance and environmental impact analysis of marine microalgal biomass production for biodiesel generation in a photobioreactor pilot plant" (2012) 39 Biomass \& Bioenergy 324.

Simonetti, Florence, "Le droit européen de l'environnement" (2008) 127 Pouvoirs 67.

Smaling, Rudolf M, "Environmental Barriers to Widespread Implementation of Biofuels" (2007-2008) 2 Envtl \& Energy L \& Pol’y J 287.

Smith, Pete et al, "2014: Agriculture, Forestry and Other Land Use (AFOLU)", in IPCC, Climate Change 2014: Mitigation of Climate Change (Cambridge: Cambridge University Press, 2014).

Speck, Stefan, "The Design of Carbon and Broad-based Energy Taxes in European Countries" (2008-2009) 10 Vt J Envt L 31.

Stame, Nicoletta, "Theory-based Evaluation and Types of Complexity" (2004) 10:1 Evaluation 58.

Steele, Katie, "The Precautionary Principle: A New Approach to Public Decisionmaking?" (2006) 5 Law, Probability and Risk 19. 
Stein, Roland M, "Import of Biofuels and the Marketing of Biofuels in the European Union: an Analysis of the Current Law on Customs, Energy Taxes and Biofuel Quotas" (2008) 26 J Energy \& Nat'l Res L 600.

Stone, Christopher, "Is there a Precautionary Principle?" (2001) 31 Environmental Law Reporter 10790.

van Vooren, Bart, "EU external energy policy: the legal and policy impact of the new competence", in Martin Trybus \& Luca Rubini, eds, The Treaty of Lisbon and the Future of European Law and Policy (Cheltenham, UK: Edward Elgar, 2012).

Vedder, Hans, "The Treaty of Lisbon and European Environmental Law and Policy" (2010) 22:2 J Envtl L 285.

von Homeyer, Ingmar, "The Evolution of EU Environmental Governance", in Joanne Scott, ed, Environmental Protection: European Law and Governance (Oxford: Oxford University Press, 2009).

Wessel, Ramses A, "Reconsidering the Relationship between International and EU Law: Towards a Content-Based Approach?" in Enzo Cannizzaro, Paolo Palchetti \& Ramses A Wessel, eds, International Law as Law of the European Union (Leiden: Martinus Nijhoff, 2012).

\section{Other Materials}

Allen, Ben et al, Space for energy crops - assessing the potential contribution to Europe's energy future (London: Institute for European Environmental Policy, 2014).

Bauen, Ausilio et al, Bioenergy - A Sustainable and Reliable Energy Source, (Paris: International Energy Agency, 2009).

Bourguignon, Didier, EU biofuels policy - Dealing with indirect land use change (Brussels: European Parliamentary Research Service, 2015).

Bureau of International Labor Affairs, List of Goods Produced by Child Labor or Forced Labor, US Department of Labor, September 2013.

Burnod, Perrine \& Jean-Philippe Colin, Large agricultural investments and inclusion of small farmers, Land Tenure Working Paper 23 (Rome: Food and Agriculture Organisation, 2012).

Charles, Chris et al, Biofuels - At What Cost? A review of costs and benefits of EU biofuel policies (Winnipeg: International Institute for Sustainable Development, 2013). 
Chopin, Isabelle \& Catharina Germaine-Sahl, Developing Anti-Discrimination Law in Europe, European Commission, Directorate-General for Justice, 2013.

Convention on Biological Diversity, Global Biodiversity Outlook 3 (Montréal: Secretariat of the Convention on Biological Diversity, 2010).

Deininger, Klaus et al, Rising Global Interest in Farmland: Can it Yield Sustainable and Equitable Benefits? (Washington: World Bank, 2011).

Diaz-Chavez, Rocio et al, Mandatory requirements in relation to air, soil, or water protection: analysis of need and feasibility, Final Report - Tasks 3 \& 4 (Utrecht: ECOFYS, 2013).

Directorate-General for Employment, Social Affairs and Inclusion, Industrial Relations in Europe 2014, European Commission, 2015.

Doss, Cheryl, If Women Hold Up Half the Sky, How Much of The World's Food Do They Produce? (Rome: Food and Agriculture Organisation, 2011).

EC, Communication from the Commission: 2020 by 2020 - Europe's climate change opportunity, 23 January 2008, COM(2008) 30.

EC, Communication from the Commission on a Renewable Energy Road Map, Renewable energies in the 21st century: building a more sustainable future, 10 January 2007, COM(2006) 848 .

EC, Communication from the Commission on an Action Plan for Energy Efficiency: Realising the Potential, 19 October 2006, COM(2006) 545.

EC, Communication from the Commission on Energy for the future: Renewable Sources of Energy, White paper for a community strategy and action plan, 26 November 1997, $\mathrm{COM}(97) 599$.

EC, Communication from the Commission on Environmental Taxes and Charges in the Single Market, 26 March 1997, COM(97) 9.

EC, Communication from the Commission on Tax policy in the European Union priorities for the years ahead, COM(2001) 260, [2001] OJ, C 284/6.

$\mathrm{EC}$, Communication from the Commission on the precautionary principle, 2 February $2000, \operatorname{COM}(2000) 1$.

EC, Communication from the Commission on the Renewable Energy Progress Report, 24 April 2009, COM(2009) 192 
EC, Communication from the Commission to the European Parliament, the Council, the Economic and Social Committee and the Committee of the Regions on alternative fuels for road transportation and on a set of measures to promote the use of biofuels, 7 November 2001, COM(2001) 547.

EC, Council Resolution on the Precautionary Principle, Annex III of the European Council's Nice proceedings, 7-10 December 2000.

EC, Debates of the European Parliament, Sitting of Tuesday, 16 December 2008, [2008] OJ; and EU, Parliament, Legislative Observatory, Fuels and energy from renewable sources: transition to biofuels to deliver greenhouse gas savings, Procedure 2012/0288(COD), online: <ww.europarl.europa.eu http://www.europarl.europa.eu/oeil/popups/ficheprocedure.do?lang=en\&reference=2 $\underline{012 / 0288(\mathrm{COD})}>$, accessed 20 September 2015.

EC, Joint Declaration of the European Parliament, the Council and the Commission on Practical Arrangements for the Codecision Procedure, [2007] OJ, C 145/5.

EC, Commission, Green paper: Towards a European strategy for the security of energy supply, 29 November 2000, COM(2000) 769.

EC, Commission, Green Paper: Towards a Secure, Sustainable and Competitive European Energy Network, 13 November 2008, COM(2008) 782.

EC, Commission, Proposal for a Directive of the European Parliament and of the Council on the promotion of the use of energy from renewable sources, 23 February 2008, $\operatorname{COM}(2008) 19$.

EC, Commission, White paper: European transport policy for 2010: time to decide, 12 September 2001, COM(2001) 370.

EC, Council, Presidency Conclusions, Brussels, 2 May 2007, Doc 7224/1/07 REV 1.

ECOFYS et al, Renewable energy progress and biofuels sustainability, Report submitted to the European Commission, September 2012.

EEA, Agriculture and the green economy (Copenhagen: European Environmental Agency, 2012).

- The European environment - state and outlook 2015: synthesis report (Copenhagen: European Environment Agency, 2015).

— EU bioenergy potential from a resource-efficiency perspective, EEA Report No 6/2013 (Copenhagen: European Environment Agency, 2013). 
— "European Briefings - Agriculture" in The European environment - state and outlook 2015, online: www.eea.europa.eu < http://www.eea.europa.eu/soer2015/europe/agriculture >, accessed 10 June 2015.

— , "European Briefings - Biodiversity" in The European environment - state and outlook 2015, online: www.eea.europa.eu < http://www.eea.europa.eu/soer2015/europe/biodiversity >, accessed 10 June 2015.

—_, "European briefings - Energy" in The European environment - state and outlook 2015, online: www.eea.europa.eu < http://www.eea.europa.eu/soer2015/europe/energy >, accessed 10 June 2015.

—_ "European briefings - Freshwater quality" in The European environment - state and outlook 2015, online: www.eea.europa.eu < http://www.eea.europa.eu/soer2015/europe/freshwater >, accessed 10 June 2015.

__ , "European briefings - Hydrological systems and sustainable water management" in The European environment - state and outlook 2015, online: www.eea.europa.eu < http://www.eea.europa.eu/soer-2015/europe/hydrological-systems >, accessed 10 June 2015.

—_ "European briefings - Mitigating climate change" in The European environment - state and outlook 2015, online: www.eea.europa.eu < http://www.eea.europa.eu/soer-2015/europe/mitigating-climate-change >, accessed 10 June 2015.

EEC, Council Recommendation 75/436/EURATOM, ECSC, EEC of 3 March 1975, [1987] OJ, L 169/1.

Elbehri, Aziz, Ana Segerstedt \& Pascal Liu, Biofuels and the sustainability challenge: A global assessment of sustainability issues, trends and policies for biofuels and related feedstocks (Rome: Food and Agriculture Organisation, 2013).

EU, Commission Staff Working Document Accompanying the document Renewable energy progress report, 27 March 2013, SWD(2013) 102.

EU, Communication from the Commission: A Roadmap for moving to a competitive low carbon economy in 2050, 8 March 2011, COM(2011) 112.

EU, Communication from the Commission: Energy 2020 - A strategy for competitive, sustainable and secure energy, 10 November 2010, $\operatorname{COM(2010)~} 639$.

EU, Communication from the Commission: Energy Efficiency Plan 2011, 8 March 2011, $\operatorname{COM}(2011) 109$. 
EU, Communication from the Commission on A policy framework for climate and energy in the period from 2020 to 2030, 22 January 2014, COM(2014) 15.

EU, Communication from the Commission on a proposal for a Decision of the European Parliament and of the Council on a General Union Environment Action Programme to 2020: Living well, within the limits of our planet, 29 November 2012, COM(2012) 710 final.

EU, Communication from the Commission on Implementing the Energy Efficiency Directive - Commission Guidance, 6 November 2013, COM(2013) 762.

EU, Communication from the Commission on the practical implementation of the EU biofuels and bioliquids sustainability scheme and on counting rules for biofuels, [2010] OJ, C 160/8.

EU, Communication from the Commission on the social and economic integration of the Roma in Europe, Brussels, 7 April 2010, COM(2010) 133.

EU, Communication from the Commission on voluntary schemes and default values in the EU biofuels and bioliquids sustainability scheme, [2010] OJ, C 160/1.

EU, Declaration concerning primacy, 13 December 2007, [2010] OJ, C 83/344.

EU, Report from the Commission on indirect land-use change related to biofuels and bioliquids, 22 December 2010, COM(2010) 811.

EU, Report from the Commission on the feasibility of drawing up lists of areas in third countries with low greenhouse gas emissions from cultivation, 10 August 2010, $\operatorname{COM}(2010) 427$.

EU, Statement of the Council's Reasons on the Position of the Council at first reading with a view to the adoption of a Directive of the European Parliament and of the Council amending Directive 98/70/EC relating to the quality of petrol and diesel fuels and amending Directive 2009/28/EC on the promotion of the use of energy from renewable sources, Brussels, 10 December 2014, ST 10710/2/14 REV 2 ADD 1.

EU, Commission, CAP Reform - an explanation of the main elements, 26 June 2013, online: ww.europa.eu < http://europa.eu/rapid/press-release_MEMO-13-621_en.htm $>$, accessed 15 June 2015.

EU, Commission, Clean Power for Transport: A European Alternative Fuels Strategy, 24 January 2013, COM(2013) 17.

EU, Commission, Energy Technologies and Innovation, 2 May 2013, COM(2013) 253. 
EU, Commission, Excise Duty Tables: Part II - Energy products and Electricity, July 2013, REF 1038 rev1, online: ec.europa.eu < http://ec.europa.eu/taxation_customs/resources/documents/taxation/excise_duties/ene rgy_products/rates/excise_duties-part_ii_energy_products_en.pdf $>$, accessed 5 January 2016.

EU, Commission, Executive Summary of the Impact Assessment accompanying the document Communication to the Commission on communicating outcome of the Impact Assessment related to requirements of Article 3(4) of Directive 2009/28/EC, 14 September 2012, SWD(2012) 262.

EU, Commission, Green Paper: Towards a European strategy for the security of energy supply, Directorate-General for Energy and Transport, 29 November 2000, $\operatorname{COM}(2000) 769$.

EU, Commission, Guidance note on Directive 2012/27/EU on energy efficiency, amending Directives 2009/125/EC and 2010/30/EC, and repealing Directives 2004/8/EC and 2006/32/EC - Article 7: Energy efficiency obligation schemes, 6 November 2013, SWD(2013) 451.

EU, Commission, Impact Assessment accompanying the document Directive of the European Parliament and of the Council on energy efficiency and amending and subsequently repealing Directive 2004/8 and 2006/32, 22 June 2011, SEC(2011) 779.

EU, Commission, Proposal for a Directive of the European Parliament and of the Council amending Directive 98/70/EC relating to the quality of petrol and diesel fuels and amending Directive 2009/28/EC on the promotion of the use of energy from renewable sources, 17 October 2012, COM(2012) 595.

EU, Commission, Renewable energy progress report, 27 March 2013, COM(2013) 175.

EU, Council, Common Understanding on Delegated Acts, Doc 8753/11, Brussels, 10 April 2010.

EU, Commission, Directorate-general for Climate Action, Allocation of aviation allowances in an EEA-wide Emissions Trading System - Policy, 30 January 2014, online: ec.europa.eu http://ec.europa.eu/clima/policies/transport/aviation/allowances/index_en.htm >, accessed 21 February 2014.

EU, Commission, Directorate-general for Climate Action, Guidance Document: Biomass issues in the EU ETS, MRR Guidance document No 3, 17 October 2012. 
EU, Commission, Directorate-general for Climate Action, Guidance Document: The Monitoring and Reporting Regulation - General guidance for Aircraft Operators, MRR Guidance document No 2, 16 July 2012.

EU, Commission, Directorate-general for Climate Action, Reducing emissions from transport, online: www.ec.europa.eu http://ec.europa.eu/clima/policies/transport/index_en.htm >, accessed 5 January 2016.

EU, Commission, Directorate-general for Climate Action, The 2020 climate and energy package - policy, 30 January 2014, online: ec.europa.eu < http://ec.europa.eu/clima/policies/strategies/2020/index_en.htm >, accessed 21 February 2014.

EU, Commission, Directorate-general for Climate Action, The EU Emissions Trading System (EU ETS) - Policy, 11 February 2014, online: ec.europa.eu < http://ec.europa.eu/clima/policies/ets/index_en.htm >, accessed 21 February 2014.

EU, Commission, Directorate-General for Energy, Renewable energy: 2013 Progress reports, online: ec.europa.eu < http://ec.europa.eu/energy/renewables/reports/2013_en.htm >, accessed 12 March 2014.

EU, Commission, Directorate-General for Energy, Renewable energy, Action Plans \& Forecasts, online: $\quad$ www.ec.europa.eu http://ec.europa.eu/energy/renewables/action_plan_en.htm >, accessed 12 March 2014.

EU, Commission, Directorate-general for the Environment, Introduction to the new EU Water Framework Directive, 20 February 2014, online: ec.europa.eu < http://ec.europa.eu/environment/water/water-framework/info/intro_en.htm >, accessed 24 March 2014.

EU, European Parliament, Legislative Observatory, Fuels and energy from renewable sources: transition to biofuels to deliver greenhouse gas savings, 2012/0288(COD), online: $\quad$ www.europarl.europa.eu http://www.europarl.europa.eu/oeil/popups/ficheprocedure.do?lang=en\&reference=2 $\underline{012 / 0288(\mathrm{COD})}>$, accessed 22 September 2015.

EU, European Parliament, Legislative Observatory, Promotion of the use of energy from renewable sources: "Renewable Energy Directive", 2008/0016(COD), online: www.europarl.europa.eu 
http://www.europarl.europa.eu/oeil/popups/ficheprocedure.do?lang=en\&reference=2 008/0016(COD)\#tab-0 >, accessed 22 September 2015.

EU, General Secretariat of the Council, Statements on Proposal for a Directive of the European Parliament and of the Council amending Directive 98/70/EC relating to the quality of petrol and diesel fuels and amending Directive 2009/28/EC on the promotion of the use of energy from renewable sources (first reading), Brussels, 1 December 2014, 15884/14 ADD 1 REV 1.

European Commission, Directorate-General for Energy and Transport, Green Paper: Towards a European strategy for the security of energy supply (Luxemburg: Office for Official Publications of the European Communities, 2001).

European Environment Agency, Trends and projections in Europe 2013 - Tracking progress towards Europe's climate and energy targets until 2020 (Luxembourg: Publications Office of the EU, 2013).

Evans, Alex, The Feeding of the Nine Billion: Global Food Security for the $21^{\text {st }}$ Century (London: Chatham House, 2009).

FAO, The State of Good and Agriculture - Biofuels: prospects, risks and opportunities (Rome: Food and Agriculture Organization, 2008).

- The State of Food Insecurity in the World (Rome: Food and Agriculture Organization, 2010).

Federal Republic of Germany, Progress Report under Article 22 of Directive 2009/28/EC on Promotion of the Use of Energy from Renewable Sources, online: ec.europa.eu < http://ec.europa.eu/energy/renewables/reports/2011_en.htm >, accessed 12 March 2014.

Flammini, Alessandro, Biofuels and the underlying causes of high food prices (Rome: Food and Agriculture Organization, 2008).

Food and Agriculture Organisation, World Food Summit, Rome, 1996, extracted from The Bioenergy and Food Security Project, Bioenergy and Food Security: The BEFS Analytical Framework, Environment and Natural Resources Management Series No 16 (Rome: Food and Agriculture Organisation, 2010).

Fritsche, Uwe R et al, Bioenergy Environmental Impact Analysis (BIAS): Analytical Framework, FAO Environment and Natural Resources Management Series No 46 (Rome: Food and Agriculture Organisation, 2010).

Gerasinchuk, Ivetta, State of Play on Biofuel Subsidies: Are policies ready to shift? (Winnipeg: International Institute for Sustainable Development, 2012). 
Gheewala, Shabbir et al, The Bioenergy and Water Nexus (United Nations Environment Programme, Oeko-Institut and IEA Bioenergy Task 43, 2011).

Harrabin, Roger, Call to abandon biofuels targets, BBC, 21 January 2008, online: www.bbc.co.uk < http://news.bbc.co.uk/2/hi/7199073.stm $>$, accessed 5 January 2016.

Hart, Kaley \& David Baldock, Greening the CAP: Delivering Environmental Outcomes through Pillar One (London: Institute for European Environmental Policy, 2011).

HLPE, Biofuels and food security (Rome: High Level Panel of Experts on Food Security and Nutrition, 2013).

Hoekstra, Arjen Y, Switching to biofuels could place unsustainable demands on water use, The Guardian, 28 May 2015, online: www.theguardian.com < http://www.theguardian.com/sustainable-business/2015/may/28/switching-tobiofuels-would-place-unsustainable-demands-on-water-use $>$, accessed 5 January 2016.

IEA, Energy Policies of IEA Countries - European Union 2014 (Paris: International Energy Agency, 2014).

ILA, New Delhi Declaration on Principles of International Law Relating to Sustainable Development (London: International Law Association, 2002).

ILO, Conventions, online: $\quad$ www.ilo.org http://www.ilo.org/dyn/normlex/en/f?p=NORMLEXPUB:12000:0::NO::: >, accessed 25 February 2016.

International Labour Office, Accelerating action against child labour, International Labour Conference, $99^{\text {th }}$ Session, Report I(B) (Geneva: International Labour Organisation, 2010).

- Safety and Health in Agriculture (Geneva: International Labour Organisation, 2000).

- Report of the Committee of Experts on the Application of Conventions and Recommendations, Report III (Part 1A), International Labour Conference, 103rd Session (Geneva: International Labour Organisation, 2014).

International Organization for Standardization, Environmental management - Life cycle assessment - Principles and framework, ISO 14040-2006, $2^{\text {nd }}$ ed (Geneva: ISO, 2006). 
—, Environmental management - Life cycle assessment - Requirements and guidelines, ISO 14044-2006 (Geneva: ISO, 2006).

IRENA, Road Transport: The Cost of Renewable Solutions (Abu Dhabi: International Renewable Energy Agency, 2013).

IUCN, A Global Assessment of the Environmental and Social Impacts Caused by the Production and Use of Biofuels (Gland: International Union for the Conservation of Nature, 2014).

Jager, David et al, Financing Renewable Energy in the European Energy Market (Utrecht: ECOFYS, 2011).

Jensen, Allan Astrup et al, Life Cycle Assessment - A guide to approaches, experiences and information sources, Environmental Issues Series no 6 (Copenhagen: European Environment Agency, 1997).

Jodoin, Sébastien, The Principle of Integration and Interrelationship in Relation to Human Rights and Social, Economic and Environmental Objectives, CISDL Legal Working Paper (Montreal: Centre for International Sustainable Development Law, 2005).

Jull, Charlotta et al, Recent Trends in the Law and Policy of Bioenergy Production, Promotion and Use, FAO Legal Paper \#68 (Rome: Food and Agriculture Organization, 2007).

Jung, Anna et al, Biofuels - At What Cost? Government Support for Ethanol and Biodiesel in the European Union - 2010 Update (Geneva: International Institute for Sustainable Development, 2010).

Kammen, Daniel M et al, Energy and Greenhouse Impacts of Biofuels: A Framework for Analysis, UC Berkeley Transportation Sustainability Research Center, Institute of Transportation Studies (Berkeley: UC Berkley, 2008).

Keam, S \& Nadine McCormick, Implementing Sustainable Bioenergy Production - A Compilation of Tools and Approaches (Gland, CH: IUCN, 2008).

Kretschmer, Bettina, The Land-use Implications of EU Bioenergy Policy - Going Beyond ILUC (London: Institute for European Environmental Policy, 2011).

Kretschmer, Bettina, Catherine Bowyer \& Allan Buckwell, EU Biofuel Use and Agricultural Commodity Prices: A Review of the Evidence Base (London: Institute for European Environmental Policy, 2012). 
Laing, Tim et al, Assessing the effectiveness of the EU Emissions Trading System, Centre for Climate Change Economics and Policy Working Paper No 126, Grantham Research Institute on Climate Change and the Environment Working Paper No 106, January 2013.

Lawson, Jeremy, European Energy Policy and the Transition to a Low-Carbon Economy, OECD Economics Department Working Papers No 779, (Paris: OECD Publishing, 2010).

Letter from 112 Civil Society Organisations, Re: EU biofuels policy comes at an unacceptably high economic, social and environmental cost - time to fix a failed policy, June 2013, online: www.eeb.org < http://www.eeb.org/?LinkServID=7048EFE2-5056-B741DBC7F4A2A6B6DB96\&showMeta=0\&aa $>$, accessed 15 August 2013.

Lucas, Hugo et al, Renewable Energy Jobs: Status, Prospects \& Policies (Abu Dhabi: International Renewable Energy Agency, 2011).

McGrath, Matt, Biofuels: 'Irrational' and 'worse than fossil fuels', BBC News, 15 April 2013, online: www.bbc.com < http://www.bbc.com/news/science-environment$\underline{22127123}>$, accessed 5 January 2016.

NREL, Biodiesel and Other Renewable Diesel Fuels, Pub \# NREL/FS-510-40419 (Golden, CO: National Renewable Energy Laboratory, 2006).

OECD Council Recommendation C(72)128 (1972), 14 ILM 236 (1975).

OECD Council Recommendation C(90) 177 (1991) Concerning the Use of Economic Instruments in Environmental Policy.

OECD \& IEA, Sustainable Production of Second-Generation Biofuels - Potential and perspectives in major economies and developing countries (Paris: International Energy Agency, 2010).

Office of Energy Efficiency, An Update on Renewable Diesel Infrastructure in Canada, Natural Resources Canada, 14 September 2012, online: www.oee.nrcan.gc.ca $<$ http://oee.nrcan.gc.ca/transportation/alternative-fuels/resources/18237 >, accessed 5 January 2016.

Oxfam, The Hunger Grains, Oxfam briefing paper 161, 2012, online: www.oxfam.org < https://www.oxfam.org/sites/www.oxfam.org/files/file_attachments/bp161-thehunger-grains-170912-summ-en_5.pdf >, accessed 15 August 2013.

Pachauri, Rajendra K et al, Climate Change 2014 - Synthesis Report (Geneva: Intergovernmental Panel on Climate Change, 2014). 
Permanent Forum on Indigenous Issues, State of the World's Indigenous Peoples (New York: United Nations, 2009).

Pieprzyk, Björn et al, The impact of fossil fuels - Greenhouse gas emissions, environmental consequences and socio-economic effects, Final Report, era - energy research architecture, November 2009.

Rio + 20 United Nations Conference on Sustainable Development, The future we want, 20-22 June 2012, UN Doc A/CONF.216/L.1.

Rosenthal, Elisabeth, As Biofuel Demand Grows, So Do Guatemala's Hunger Pangs, New York Times, 5 January 2013, online: www.nytimes.com < http://www.nytimes.com/2013/01/06/science/earth/in-fields-and-marketsguatemalans-feel-squeeze-of-biofuel-demand.html?ref=topics $>$, accessed 5 January 2016.

Scientific Applications International Corporation, Life cycle assessment: Principles and Practice (Cincinnati: Environmental Protection Agency, 2006).

Steer, Andrew \& Craig Hanson, Biofuels are not a green alternative to fossil fuels, 29 January 2015, The Guardian, online: www.theguardian.com < http://www.theguardian.com/environment/2015/jan/29/biofuels-are-not-the-greenalternative-to-fossil-fuels-they-are-sold-as >, accessed 5 January 2016.

Svensson, Mans et al, Migrant Agricultural Workers and Their Socio-economic, Occupational and Health Conditions-A Literature Review, SSRN Working Papers series, 2013.

Tait, Joyce et al, Biofuels: ethical issues (London: Nuffield Council on Bioethics, 2011).

Trusty, Wayne, The Environmental Side of Sustainability: Using Life Cycle Assessment to Assess True Performance, National Research Council Canada, Institute for Research in Construction, NRCC-48691, 2006.

UN, Agenda 21: Programme of Action for Sustainable Development, GA 46th Sess, Agenda Item 21, UN Doc A/Conf.151/26 (1992).

- Plan of Implementation of the World Summit on Sustainable Development, WSSD 4 September 2002, Johannesburg, UN Doc A/CONF:199/20.

UN-Energy, Sustainable Bioenergy: A Framework for Decision Makers (United Nations, 2007).

UN Special Rapporteur on the right to food, Note on the Impacts of the EU Biofuels Policy on the Right to Food, United Nations, Office of the High Commissioner for 
Human Rights, 23 April 2013, online: www.srfood.org < http://www.srfood.org/fr/special-rapporteur-urges-phase-out-of-eu-biofuel-incentives >, accessed 14 April 2014.

- Report of the Special Rapporteur on the right to food, GA, $62^{\text {nd }}$ Sess, UN Doc $\mathrm{A} / 62 / 289,(2007)$.

- Report of the Special Rapporteur on the right to food - Agribusiness and the right to food, HRC, $13^{\text {th }}$ Sess, UN Doc A/HRC/13/33, (2009).

UNEP, Toward Sustainable Production and Use of Resources: Assessing Biofuels (Nairobi: United Nations Environmental Program, 2009).

United States Department of Energy, Secretary Moniz's remarks on the importance of biofuels to America's clean energy future, 1 August 2013, online : www.energy.gov $<\quad$ http://energy.gov/articles/secretary-moniz-biofuels-important-americas-energyfuture $>$, accessed 5 January 2016.

United States Department of Energy, Alternative Fuels Data Center, Ethanol Fuels Basics, online: www.afdc.energy.gov http://www.afdc.energy.gov/afdc/ethanol/basics.html >, accessed 5 January 2016.

van Iersel, Sjors et al, Algae-based Biofuels: A Review of Challenges and Opportunities for Developing Countries (Rome: Food and Agriculture Organisation, 2009).

Victor, David, The Politics of Fossil-Fuel Subsidies (Winnipeg: International Institute for Sustainable Development, 2009).

Wald, Matthew L, Fuel From Waste, Poised at a Milestone, New York Times, 13 November 2012, online: <ww.nytimes.com < http://www.nytimes.com/2012/11/14/business/energy-environment/alternative-fuelslong-delayed-promise-might-be-near-fruition.html >, accessed 5 January 2016.

World Commission on Environment and Development, Our Common Future, 4 Aug. 1987, UN GA Res., A/42/427 (1987).

Webb, Annie \& David Coates, Biofuels and Biodiversity, CBD Technical Series No 65 (Montréal: Secretariat of the Convention on Biological Diversity, 2012).

WWF, Living Planet Report 2012 (Gland, CH: World Wildlife Fund, 2012). 